Prepared in cooperation with the Nebraska Natural Resources Commission; Nebraska Department of Natural Resources; and Lower Platte North, Lower Platte South, Papio-Missouri River, Nemaha, Lower Loup, Central Platte, Upper Elkhorn, Lower Elkhorn, Lower Niobrara, and Lewis and Clark Natural Resources Districts

\title{
Interpretation of Hydrogeologic Data to Support Groundwater Management, Bazile Groundwater Management Area, Northeast Nebraska, 2019-A Case Demonstration of the Nebraska Geocloud
}

Scientific Investigations Report 2020-5113 Version 1.1, December 2020 



\section{Interpretation of Hydrogeologic Data to Support Groundwater Management, Bazile Groundwater Management Area, Northeast Nebraska, 2019-A Case Demonstration of the Nebraska Geocloud}

By Christopher M. Hobza and Gregory V. Steele

Prepared in cooperation with the Nebraska Natural Resources Commission; Nebraska Department of Natural Resources; and Lower Platte North, Lower Platte South, Papio-Missouri River, Nemaha, Lower Loup, Central Platte, Upper Elkhorn, Lower Elkhorn, Lower Niobrara, and Lewis and Clark Natural Resources Districts

Scientific Investigations Report 2020-5113

Version 1.1, December 2020 


\title{
U.S. Department of the Interior \\ DAVID BERNHARDT, Secretary
}

\author{
U.S. Geological Survey \\ James F. Reilly II, Director
}

\author{
U.S. Geological Survey, Reston, Virginia: 2020 \\ First release: December 2020 \\ Revised: December 15, 2020 (ver 1.1)
}

For more information on the USGS - the Federal source for science about the Earth, its natural and living resources, natural hazards, and the environment—visit https://www.usgs.gov or call 1-888-ASK-USGS.

For an overview of USGS information products, including maps, imagery, and publications, visit https://store.usgs.gov/.

Any use of trade, firm, or product names is for descriptive purposes only and does not imply endorsement by the U.S. Government.

Although this information product, for the most part, is in the public domain, it also may contain copyrighted materials as noted in the text. Permission to reproduce copyrighted items must be secured from the copyright owner.

Suggested citation:

Hobza, C.M., and Steele, G.V., 2020, Interpretation of hydrogeologic data to support groundwater management, Bazile Groundwater Management Area, northeast Nebraska, 2019-A case demonstration of the Nebraska Geocloud (ver. 1.1, December 15, 2020): U.S. Geological Survey Scientific Investigations Report 2020-5113, 46 p., https://doi.org/10.3133/sir20205113.

Associated data for this publication:

Hobza, C.M., 2020, Interpolated groundwater-level surface, spring 2017, Bazile Groundwater Management Area, northeastern Nebraska: U.S. Geological Survey data release, https://doi.org/10.5066/P9F3RVXN.

ISSN 2328-0328 (online) 


\section{Acknowledgments}

The authors would like to thank the sponsors and funding agencies for the Nebraska Geocloud project, which includes the Nebraska Natural Resources Commission; Nebraska Department of Natural Resources; and the Lewis and Clark, Lower Elkhorn, Lower Platte North, Lower Platte South, Papio-Missouri River, Nemaha, Lower Loup, and Central Platte Natural Resources Districts. The authors would like to thank the managers of the Upper Elkhorn, Lower Elkhorn, Lower Niobrara, and Lewis and Clark Natural Resource Districts for their support and for providing water-level data needed for this report. The authors thank Sue Lackey of the University of Nebraska Conservation and Survey Division for providing technical expertise in the hydrogeology of the study area and understanding the needs and concerns of the local water resource managers. The authors thank Dan Snow of University of Nebraska-Lincoln for his helpful suggestions to focus the report scope. We also thank Katie Cameron, Eastern Nebraska Water Resources Assessment coordinator, and Dr. Jesse Korus of University of Nebraska-Lincoln for being the technical and administrative leads of the Nebraska Geocloud project. The authors also thank Jim Cannia and Jared Abraham from Aqua Geo Frameworks for their technical expertise in processing and interpreting airborne electromagnetic data. 



\section{Contents}

Acknowledgments ……...................................................................................................................

Abstract

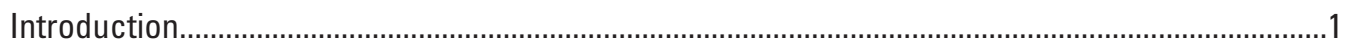

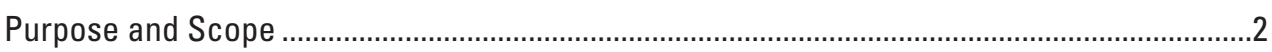

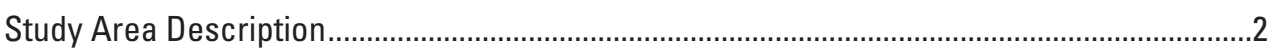

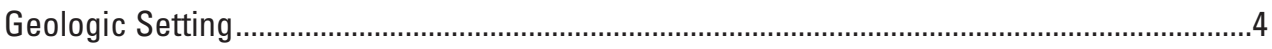

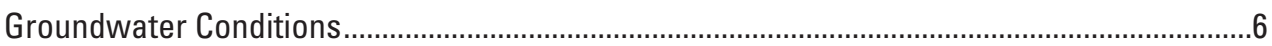

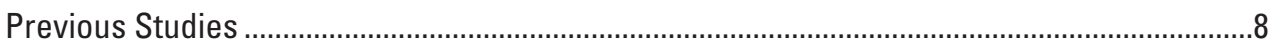

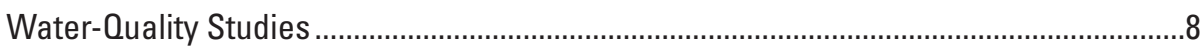

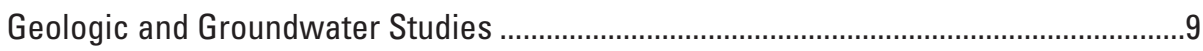

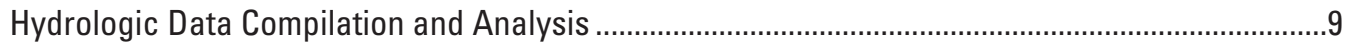

Source Data Description and Processing ..............................................................................

Airborne Electromagnetic Surveys................................................................................... 10

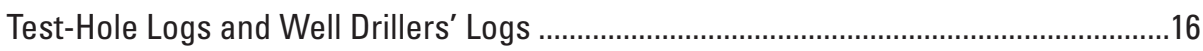

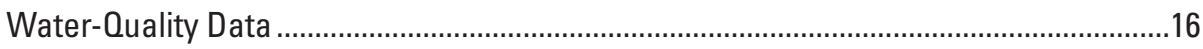

Discrete and Continuous Water-Level Data...................................................................18

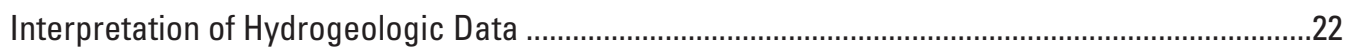

Interpretation of Water-Quality and Age Tracer Data .......................................................22

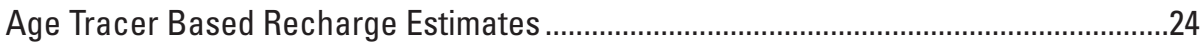

Pesticide-Based Recharge Estimates.......................................................................

Interpretation of Continuous Water-Level Data...............................................................29

Potential Future Data Collection to Inform Groundwater Management .........................................35

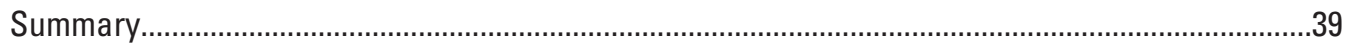

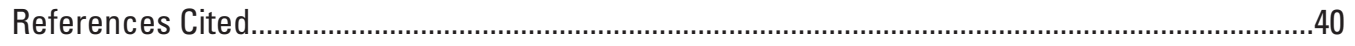

\section{Figures}

1. Map showing study area of the Bazile Groundwater Management Area, Nebraska ......3

2. Map showing streams, measured groundwater levels, and interpreted water-level surface for the High Plains aquifer within the Bazile Groundwater Management Area, spring 2017

3. Maps showing airborne electromagnetic survey lines collected within the Bazile Groundwater Management Area.

4. Map showing selected test-hole, water-level, and water-quality data assembled and imported into the Geoscene3D project.

5. Example airborne electromagnetic and water-quality data displayed within the Geoscene3D program

6. Interpreted geologic material of airborne electromagnetic profile L128701 and nitrate concentration of wells ML-6S, ML-6M, and ML-6D...

7. Interpreted geologic material of airborne electromagnetic profile L125900301 and nitrate concentration of wells $2 \mathrm{D}$ and $2 \mathrm{M}$.

8. Interpreted geologic material of airborne electromagnetic profile L125900401 and nitrate concentration of wells 15D, 15M, and 15S. 
9. Interpreted geologic material of airborne electromagnetic profile L125900401 and location of three irrigation wells with detectable concentrations of pesticides .....30

10. Graph showing continuous groundwater-level elevation data for monitoring wells 19S and 19M, Lower Elkhorn Natural Resources District, 2015-16 .31

11. Interpreted geologic material of airborne electromagnetic profile L124900, monitoring wells $19 \mathrm{~S}$ and $19 \mathrm{M}$, and test hole 1-LE-03

12. Graph showing continuous groundwater-level elevation data for monitoring wells 3 S and 3M, Lower Elkhorn Natural Resources District, 2015-18

13. Interpreted geologic material of airborne electromagnetic (AEM) profile L125300 and nitrate concentration of wells 3D and 3S

14. Graph showing continuous groundwater-level data for monitoring wells $9 \mathrm{M}$ and 9D, Upper Elkhorn Natural Resources District, 2013-17

15. Interpreted geologic material of airborne electromagnetic data projected onto user-defined profiles centering on monitoring wells $9 \mathrm{M}$ and $9 \mathrm{D}$ and test hole 2-UE-01.

16. Graph showing nitrate concentration of sampled groundwater from monitoring wells 9M and 9D, Upper Elkhorn Natural Resources District, 2002-14.

17. Graph showing continuous groundwater-level data for monitoring well 14S, Upper Elkhorn Natural Resources District, 2014-17

18. Interpreted geologic material for airborne electromagnetic (AEM) profile L125900501 and nitrate concentration of monitoring wells 14S and 14M ...

\section{Tables}

1. Geologic and hydrostratigraphic units and descriptions, Bazile Groundwater Management Area, northeastern Nebraska...

2. Data sources and supporting information used in Geoscene3D project

3. Measured water levels in wells completed in the High Plains aquifer within the Bazile Groundwater Management Area, spring 2017.

4. Monitoring wells completed in the High Plains aquifer where continuous water-level data were recorded within the Bazile Groundwater Management Area, 2013-18

5. Summary of selected water-quality data and groundwater age estimates from wells sampled within the Bazile Groundwater Management Area, 2000-17

6. Pesticide concentration, nitrate concentration, and calculated apparent groundwater ages for sampled monitoring and irrigation wells with detectable concentrations of pesticides, 1995-2005. 


\section{Conversion Factors}

International System of Units to U.S. customary units

\begin{tabular}{|c|c|c|}
\hline Multiply & By & To obtain \\
\hline \multicolumn{3}{|c|}{ Length } \\
\hline centimeter $(\mathrm{cm})$ & 0.3937 & inch (in.) \\
\hline meter $(\mathrm{m})$ & 3.281 & foot $(\mathrm{ft})$ \\
\hline kilometer (km) & 0.6214 & mile (mi) \\
\hline meter (m) & 1.094 & yard (yd) \\
\hline \multicolumn{3}{|c|}{ Area } \\
\hline square kilometer $\left(\mathrm{km}^{2}\right)$ & 247.1 & acre \\
\hline square kilometer $\left(\mathrm{km}^{2}\right)$ & 0.3861 & square mile $\left(\mathrm{mi}^{2}\right)$ \\
\hline hectare (ha) & 2.471 & acre \\
\hline hectare (ha) & 0.003861 & square mile $\left(\mathrm{mi}^{2}\right)$ \\
\hline \multicolumn{3}{|c|}{ Volume } \\
\hline liter $(\mathrm{L})$ & 0.2642 & gallon (gal) \\
\hline \multicolumn{3}{|c|}{ Hydraulic conductivity } \\
\hline meter per day $(\mathrm{m} / \mathrm{d})$ & 3.281 & foot per day (ft/d) \\
\hline \multicolumn{3}{|c|}{ Recharge rate } \\
\hline centimeters per year $(\mathrm{cm} / \mathrm{yr})$ & 0.3937 & inches per year (in/yr) \\
\hline
\end{tabular}

Temperature in degrees Celsius $\left({ }^{\circ} \mathrm{C}\right)$ may be converted to degrees Fahrenheit $\left({ }^{\circ} \mathrm{F}\right)$ as

${ }^{\circ} \mathrm{F}=\left(1.8 \times{ }^{\circ} \mathrm{C}\right)+32$.

Temperature in degrees Fahrenheit $\left({ }^{\circ} \mathrm{F}\right)$ may be converted to degrees Celsius $\left({ }^{\circ} \mathrm{C}\right)$ as ${ }^{\circ} \mathrm{C}=\left({ }^{\circ} \mathrm{F}-32\right) / 1.8$.

\section{Datum}

Vertical coordinate information is referenced to the North American Vertical Datum of 1988 (NAVD 88).

Horizontal coordinate information is referenced to the North American Datum of 1983 (NAD 83). Elevation, as used in this report, refers to distance above the vertical datum.

\section{Supplemental Information}

Concentrations of chemical constituents in water are given in either milligrams per liter (mg/L) or micrograms per liter $(\mu \mathrm{g} / \mathrm{L})$. 


\section{Abbreviations}

$\begin{array}{ll}\text { 3D } & \text { three-dimensional } \\ \text { AEM } & \text { airborne electromagnetic } \\ \text { BGMA } & \text { Bazile Groundwater Management Area } \\ \text { CSD } & \text { University of Nebraska-Lincoln Conservation and Survey Division } \\ \text { DOI } & \text { depth of investigation } \\ \text { ENWRA } & \text { Eastern Nebraska Water Resources Assessment } \\ \text { EPSG } & \text { European Petroleum Survey Group } \\ \text { GIS } & \text { geographic information system } \\ \text { MCL } & \text { maximum contaminant level } \\ \text { NAVD 88 } & \text { North American Vertical Datum of } 1988 \\ \text { NRD } & \text { Natural Resources District } \\ \text { NWIS } & \text { National Water Information System } \\ \text { TDEM } & \text { time-domain electromagnetic } \\ \text { USGS } & \text { U.S. Geological Survey }\end{array}$




\title{
Interpretation of Hydrogeologic Data to Support Groundwater Management, Bazile Groundwater Management Area, Northeast Nebraska, 2019-A Case Demonstration of the Nebraska Geocloud
}

\author{
By Christopher M. Hobza and Gregory V. Steele
}

\section{Abstract}

Nitrate, age tracer, and continuous groundwater-level data were interpreted in conjunction with airborne electromagnetic (AEM) survey data to understand the movement of nitrate within the Bazile Groundwater Management Area (BGMA) in northeastern Nebraska. Previously published age tracer data and nitrate data indicated vertical stratification of groundwater quality. Younger groundwater sampled within shallow parts of the aquifer had higher concentrations of nitrate, with 70 percent exceeding the U.S. Environmental Protection Agency maximum contaminant level of 10 milligrams per liter. In contrast, groundwater sampled from deeper parts of the aquifer indicated that nitrate concentrations were less than 2 milligrams per liter and that groundwater likely recharged prior to widespread use of commercial fertilizer.

The hydrostratigraphic interpretation of AEM profiles indicated that shallow and deep monitoring wells were often screened within the same homogenous zone of aquifer material. In contrast, test-hole logs indicated that there often are fine-grained layers within these homogenous zones that separate the shallow and deep monitoring well screens, but these fine-grained layers are not detected by the AEM technique because of decreased resolution of the AEM technique with depth.

The stratification of groundwater ages and nitrate concentrations likely was caused by groundwater-flow paths of different length, location and time of recharge, and denitrification. Within paleochannels interpreted from AEM and test-hole data, pesticides detected in groundwater generally coincide with elevated nitrate concentrations. Continuous groundwaterlevel data from four monitoring well nests indicated that groundwater pumping can impose or increase downward hydraulic gradients and facilitate the downward movement of nitrate into deeper parts of the High Plains aquifer. Given the density of irrigation wells within the BGMA, this effect on the hydraulic gradient is likely prevalent in other areas of the BGMA. Understanding seasonal water-level changes can allow water managers to better predict and assess the hydraulic gradient and the vulnerability of groundwater in deeper parts of the High Plains aquifer.

Nitrate, age tracer, and continuous groundwater-level data within the BGMA were interpreted in conjunction with AEM data as a case demonstration of the Nebraska Geocloud. The Nebraska Geocloud was initiated to protect taxpayer investments in AEM data collection and realize maximum benefit of these data by creating a publicly available, online digital database for long-term data storage. The Lower Platte North, Lower Platte South, Papio-Missouri River, Nemaha, Lower Loup, Central Platte, Upper Elkhorn, Lower Elkhorn, Lower Niobrara, and Lewis and Clark Natural Resources Districts; the University of Nebraska-Lincoln Conservation and Survey Division, Nebraska Natural Resources Commission, Nebraska Department of Natural Resources; and the U.S. Geological Survey entered a cooperative agreement to begin a program of data management and research aimed at understanding the best use of AEM for groundwater sustainability and management. Resulting case-study interpretations are provided to guide use of the Nebraska Geocloud to assess water-quality conditions and can be used by water managers and staff to address applicable water resource problems.

\section{Introduction}

Airborne electromagnetic (AEM) geophysical surveys have greatly advanced hydrogeologic mapping and groundwater management efforts in Nebraska by providing cost-effective, high-resolution subsurface information. From 2007 to 2019, 13 Nebraska Natural Resources Districts (NRDs), the University of Nebraska-Lincoln's Conservation and Survey Division (CSD), and the U.S. Geological Survey (USGS) invested nearly \$18 million to acquire more than 32,000 line-kilometers (20,000 line-miles) of AEM data in Nebraska (Katie Cameron, Eastern Nebraska Water Resources Assessment, written commun., 2019). Despite the large investments in data collection, there has been no coordinated 
effort to assemble, inventory, and manage the AEM data and their interpretation for long-term preservation in a centralized digital network. Furthermore, data reporting requirements have not been standardized for AEM surveys not contracted by the USGS, and the effectiveness of various AEM hydrogeologic mapping methods has not been evaluated. For a given area, AEM data from different surveys may be stored in different places and maintained by more than one entity. As a result, water managers or researchers may miss key opportunities to use all the available information. To date (2020), much scientific work is needed to understand how AEM data can be effectively used to map hydrogeologic units in various geologic settings within Nebraska. To protect taxpayer investments in AEM and realize maximum benefit of these data, the Lower Platte North, Lower Platte South, Papio-Missouri River, Nemaha, Lower Loup, Central Platte, Upper Elkhorn, Lower Elkhorn, Lower Niobrara, and Lewis and Clark NRDs; the CSD; the Nebraska Natural Resources Commission; the Nebraska Department of Natural Resources; and the USGS entered a cooperative agreement to begin a program of data management and research aimed at understanding the best use of AEM for groundwater sustainability and management. The USGS and CSD are working jointly to provide technical support to cooperating NRDs to implement an AEM data preservation and research program titled the "Nebraska Geocloud." The Nebraska Geocloud project (Richter-Ryerson, 2017) will facilitate data archiving and public access to information and provide guidelines that will maximize cost-effectiveness of future AEM studies within the State of Nebraska.

As a case demonstration of the Nebraska Geocloud and as part of the AEM data preservation and research program, this report demonstrates how publicly available hydrogeologic data including water-quality, water-level, and AEM data covering the Bazile Groundwater Management Area (BGMA; fig. 1) can be assembled and jointly interpreted to assist managers in making future water resource decisions. The BGMA (Upper Elkhorn Natural Resources District, 2016) was created in response to water-quality concerns in parts of Knox, Antelope, and Pierce Counties (Upper Elkhorn Natural Resources District, 2016; fig. 1) that were first documented in 1990 (Gosselin, 1991). In addition to water-quality concerns, groundwater pumping has reduced groundwater discharge to cool water streams, including the East Branch of Verdigre Creek (fig. 1), which is a valuable recreational resource for the State of Nebraska (Hendee, 2015).

Recent AEM surveys (Cannia and others, 2017a, b; Carney and others, 2015a) mapped portions of the BGMA to improve the understanding of aquifer properties, estimate the volume of available water in storage, and assess the vulnerability of the aquifer from surface contamination. The current study interpreted additional high-density geophysical data (Cannia and others, 2017a, b; Carney and others, 2015a), in combination with previously published water-quality and water-level data, to improve the understanding of aquifer properties and helped assess the vulnerability of aquifer contamination within the BGMA. Needs for future data collection and monitoring were also identified to assist water managers within the Upper Elkhorn, Lower Elkhorn, Lower Niobrara, and Lewis and Clark NRDs (fig. 1) in reducing nitrate concentrations in groundwater and surface water and addressing water-supply concerns within the BGMA.

\section{Purpose and Scope}

The purpose of this report is to present analyses of hydrogeologic data to support groundwater management within the BGMA in northeastern Nebraska. The hydrogeologic data were assembled from publicly available sources and analyzed within a three-dimensional (3D) environment for a comprehensive interpretation that demonstrates the utility of the Nebraska Geocloud (Richter-Ryerson, 2017). The Nebraska Geocloud is a cloud-based online geodatabase that allows the user to select and download hydrogeologic data to the Geoscene3D software package (I-GIS, 2019). The Nebraska Geocloud uses Geoscene3D, which provides an integrated, 3D geological modeling environment by combining waterquality and water-level data in geographic information system (GIS) format, lithologic and borehole geophysical logs from test holes, and AEM or other geophysical data (I-GIS, 2019). Resulting case-study interpretations are provided to guide use of the Nebraska Geocloud to assess water-quality conditions that can be used by water managers and staff and researchers to assess water-quality and hydrogeologic characteristics to better understand and address applicable water resource problems.

\section{Study Area Description}

The study area for this report is the BGMA in northeast Nebraska, which is approximately 1,950 square kilometers $\left(\mathrm{km}^{2}\right)$ in size and covers parts of Knox, Antelope, and Pierce Counties and four NRDs (Upper Elkhorn, Lower Elkhorn, Lower Niobrara, and Lewis and Clark; fig. 1). Precipitation and groundwater contribute to three stream systems in the BGMA, including Bazile Creek, which is a tributary to the Missouri River (not shown on any maps); Verdigre Creek, which is a tributary to the Niobrara River (not shown on any maps); and North Fork of the Elkhorn River, which is a tributary to the Elkhorn River (fig. 1). The BGMA is a geologically complex area along the western edge of incised glacial till area in Nebraska and the northern margin of the nationally important High Plains aquifer (fig. 1; Qi, 2010; Conservation and Survey Division, University of Nebraska-Lincoln, 2019b). Topography varies across the BGMA; however, much of the area is nearly flat and characterized as plains (Conservation and Survey Division, University of Nebraska-Lincoln, 2019c). The topography in the eastern and northeastern parts of the BGMA are characterized as rolling hills (Conservation and Survey Division, University of Nebraska-Lincoln, 2019c). In the northwestern part of the BGMA, near Verdigre Creek and 


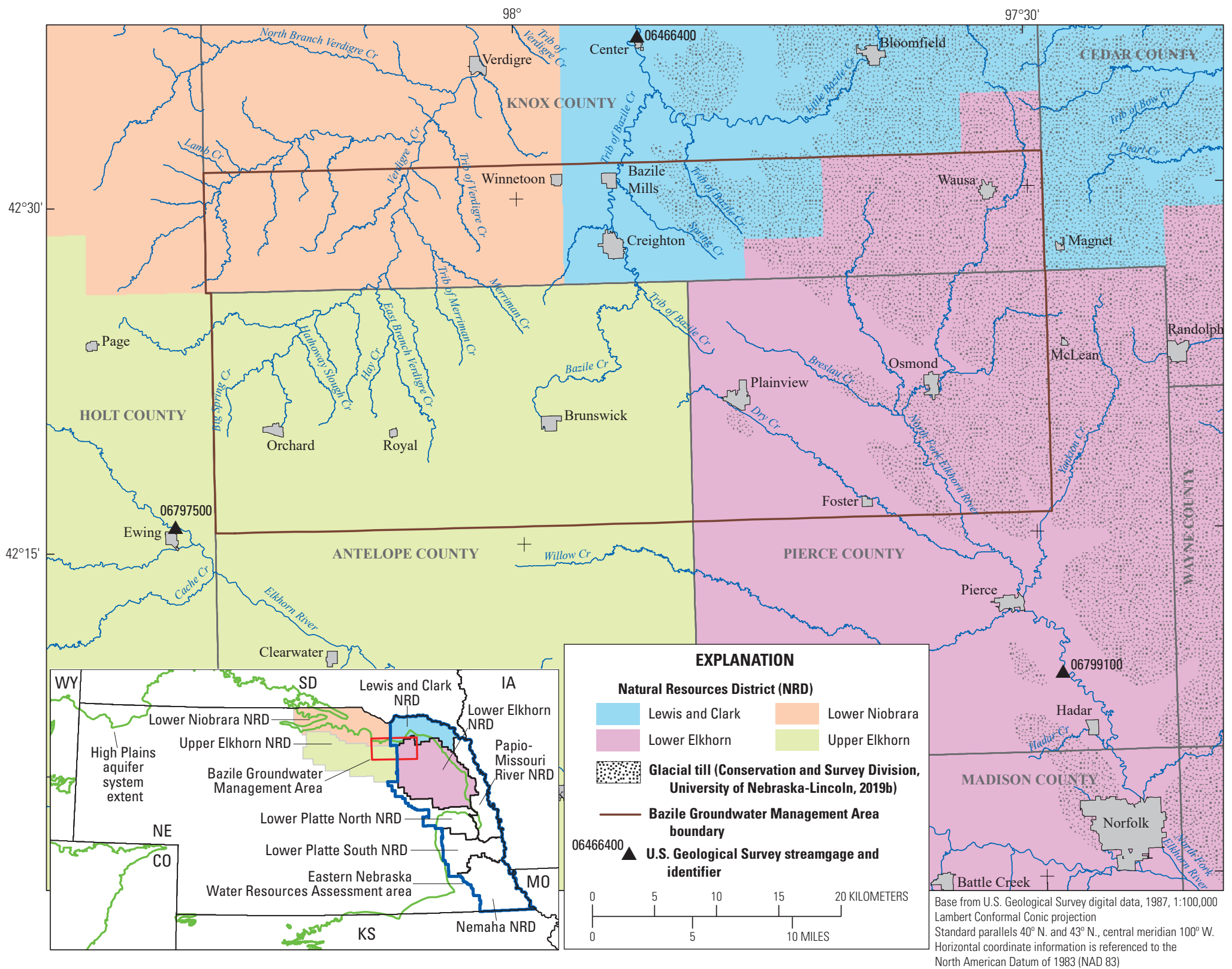

Figure 1. Study area of the Bazile Groundwater Management Area, Nebraska. 
its tributaries, the topography is characterized as dissected plains, bluffs, and escarpments (Conservation and Survey Division, University of Nebraska-Lincoln, 2019c).

The climate in the study area is typical of continental midlatitude locations, characterized by cold winters and warm summers (National Center for Environmental Information, 2019). From 1981 to 2010, at Creighton, Nebraska, the average annual low temperature for the winter was -10.9 degrees Celsius $\left({ }^{\circ} \mathrm{C}\right)$ and the average annual high temperature was $28.9^{\circ} \mathrm{C}$ (National Center for Environmental Information, 2019; fig. 1). During that same period, the average annual precipitation was 70.1 centimeters per year (National Center for Environmental Information, 2019). In the BGMA area, nearly 75 percent of the annual precipitation falls within the growing season for row crops, which is considered to be from April through September (Stanton and others, 2011). Potential evaporation in this area is greatest during the crop-growing season of April through September (Stanton and others, 2011).

In the BGMA, much of the land is used for agricultural purposes (Center for Advanced Land Management Information Technologies, 2007). Approximately 32 percent of the study area is classified as irrigated cropland, 27 percent dryland crops, 37 percent pasture, and all other land uses combine to approximately 4 percent based on 2005 land use data (Center for Advanced Land Management Information Technologies, 2007).

Within the study area, groundwater primarily is used for domestic, irrigation, and public water supply (Dieter and others, 2018). As of 2013, approximately 75 percent of all registered wells were irrigation wells (Upper Elkhorn Natural

Resources District, 2016). Because water-use data are reported on a countywide level, numbers specific to the study area were not available. Countywide water-use estimates for 2010 and 2015 indicate that water use has been increasing within the three counties containing the BGMA, which is most likely in response to increases in groundwater-irrigated acres for each of the three counties (Maupin and others, 2014; Dieter and others, 2018). Groundwater use for domestic and public supply purposes had decreased slightly from 2010 to 2015 for each of the three counties, which corresponds with slight decreases in population (Maupin and others, 2014; Dieter and others, 2018). The BGMA contains nine public water-supply systems serving approximately 5,000 people (Upper Elkhorn Natural Resources District, 2016).

\section{Geologic Setting}

The BGMA is at the northeastern edge of the High Plains aquifer system, which is the primary aquifer for the study area (fig. 1). The High Plains aquifer is inclusive of all hydrologically connected Tertiary-age and Quaternary-age units (table 1). Within the BGMA, these units include the Mioceneage Ogallala Formation, Pliocene-age Broadwater Formation, and undifferentiated Pleistocene- and Quaternary-age deposits. The Late Cretaceous-age Niobrara Formation of the Colorado
Group (hereafter referred to as the "Niobrara Formation"), and Late Cretaceous-age Pierre Shale and Eocene-age Chadron Formation of the White River Group (hereafter referred to as the "Chadron Formation") unconformably underlie the hydrostratigraphic units of the High Plains aquifer (table 1; Burchett and others, 1988; Diffendal and others, 2008; McGuire and Peterson, 2008; Korus and Joeckel, 2011).

The geologic history relevant to this study begins roughly 70 million years ago with the deposition of Cretaceous-age sediments (Gutentag and others, 1984). During the Cretaceous period, much of the study area was covered by a shallow inland sea, where marine sediments were deposited to form the Niobrara Formation and the Pierre Shale. The Niobrara Formation is locally described as a shaly chalk or limestone (Korus and Joeckel, 2011) and typically is not used as a water source where younger, more permeable units are present. In some locations, where fractures are present, such as in Pierce and Madison Counties (fig. 1), saturated deposits in the Niobrara Formation can yield water to domestic, stock, and municipal wells (Gutentag and others, 1984). The Pierre Shale is described as a shale with minor shaly chalk, siltstone, and sandstone intervals (Korus and Joeckel, 2011). The Pierre Shale is thickest in the western part of the BGMA and pinches out in the southeast corner (Burchett and others, 1988; Cannia and others, 2017a, b). The top of the Cretaceous units forms the base of the principal aquifer for most of the BGMA area (Gutentag and others, 1984; McGuire and Peterson, 2008; Cannia and others, 2017a).

The oldest Tertiary-age unit within the BGMA is the Chadron Formation, which is also known as the Chamberlain Pass Formation by the CSD, University of Nebraska-Lincoln (Diffendal and others, 2008). The Chadron Formation is locally described as a sandy silt valley-fill deposit and occurs in isolated pockets within the BGMA (Diffendal and others, 2008). Using primarily test-hole data, McGuire and Peterson (2008) determined that the top of the Chadron Formation or other formations within the White River Group formed the base of the aquifer within parts of the BGMA area. Cannia and others (2017b) reported that the Chadron Formation exists in isolated pockets throughout the BGMA; however, the Chadron Formation was not interpreted in the AEM data by Cannia and others (2017b).

The Ogallala Formation is the principal geologic unit in the High Plains aquifer system and is thickest in Antelope County (Souders and Shaffer, 1969). The Ogallala Formation consists of a poorly sorted mixture of sand, silt, clay, and gravel (Condra and Reed, 1943) and is generally unconsolidated or weakly consolidated but can contain layers of sandstone cemented by calcium carbonate or limestone. Within the BGMA, the Ogallala Formation has not been subdivided into stratigraphic units recognized in other areas because of the difficulty correlating these units in the subsurface with available test-hole data. The Ogallala Formation was deposited by aggrading streams that filled paleovalleys, which were eroded into pre-Ogallala Formation rocks (Swinehart and others, 1985). The base of the Ogallala Formation is 
Table 1. Geologic and hydrostratigraphic units and descriptions, Bazile Groundwater Management Area, northeastern Nebraska.

[Ma, millions of years ago; BGMA, Bazile Groundwater Management Area; m, meter]

\begin{tabular}{|c|c|c|c|c|c|c|c|}
\hline System & Series & Age (Ma) 1 & Geologic unit & Geologic description 1 & \multicolumn{2}{|r|}{ Hydrostratigraphic unit } & Hydrogeologic description 1 \\
\hline \multirow[t]{2}{*}{ Quaternary } & Holocene & Present to 0.01 & \multirow[t]{2}{*}{$\begin{array}{l}\text { Undifferentiated } \\
\text { Quaternary de- } \\
\text { posits }\end{array}$} & $\begin{array}{l}\text { Loess, till, eolian sand, } \\
\text { and alluvial deposits }\end{array}$ & \multirow{4}{*}{$\begin{array}{l}\text { High } \\
\text { Plains } \\
\text { aquifer } \\
\text { system }\end{array}$} & Alluvial aquifer & $\begin{array}{l}\text { Can provide low yield wells, } \\
\text { unconfined, fine-grained } \\
\text { glacial till caps more perme- } \\
\text { able units in northeast part of } \\
\text { BGMA }\end{array}$ \\
\hline & Pleistocene & 0.01 to 2.6 & & \multirow{2}{*}{$\begin{array}{l}\text { Sand, gravel, interbed- } \\
\text { ded silt }\end{array}$} & & \multirow{2}{*}{$\begin{array}{c}\text { Pliocene-Pleistocene sand and } \\
\text { gravel }\end{array}$} & \multirow{2}{*}{$\begin{array}{l}\text { Up to } 50 \mathrm{~m} \text { thick, used as } \\
\text { primary water source when } \\
\text { present }\end{array}$} \\
\hline \multirow{3}{*}{ Tertiary } & Pliocene & 2.6 to 5.3 & $\begin{array}{r}\text { Broadwater } \\
\text { Formation }\end{array}$ & & & & \\
\hline & Miocene & 5.3 to 19 & Ogallala Formation & $\begin{array}{l}\text { Poorly sorted mixture } \\
\text { of sand, silt, clay, } \\
\text { and gravel. Generally } \\
\text { unconsolidated to } \\
\text { weakly consolidated. } \\
\text { Maximum thickness of } \\
100 \mathrm{~m} \text { in test holes }\end{array}$ & & Ogallala Formation & $\begin{array}{l}\text { Unconfined to semi-confined, } \\
\text { generally moderate- to high- } \\
\text { yielding water-bearing yields } \\
\text { depend on locality and vary } \\
\text { greatly. }\end{array}$ \\
\hline & Eocene & 34 to 38 & $\begin{array}{c}\text { Chadron Formation } \\
\text { of the White River } \\
\text { Group }^{2}\end{array}$ & $\begin{array}{l}\text { Sandy silt valley-fill } \\
\text { deposit, occurs in } \\
\text { isolated pockets }\end{array}$ & & Chadron Formation ${ }^{2}$ & $\begin{array}{l}\text { Top of unit forms base of High } \\
\text { Plains aquifer where present }\end{array}$ \\
\hline & & & Pierre Shale & $\begin{array}{l}\text { Gray to black marine } \\
\text { shale }\end{array}$ & & rre Shale confining unit & $\begin{array}{l}\text { Confining unit, not a source of } \\
\text { water }\end{array}$ \\
\hline Cretaceous & $\begin{array}{l}\text { Upper } \\
\text { Cretaceous }\end{array}$ & 65 to ?? & $\begin{array}{c}\text { Niobrara Formation } \\
\text { of the Colorado } \\
\text { Group }\end{array}$ & Shaly chalk, limestone & & Niobrara Formation & $\begin{array}{l}\text { Not a water source within the } \\
\text { BGMA but can yield water } \\
\text { when fractured }\end{array}$ \\
\hline
\end{tabular}

${ }_{1}^{1 G e o l o g i c}$ and hydrogeologic descriptions modified from Gosselin (1991), Diffendal and others (2008), Cannia and others (2017b); ages from Diffendal and others (2008) and Korus and Joeckel (2011).

${ }^{2}$ Recognized as the Chamberlain Pass Formation by the University of Nebraska Conservation and Survey Division (Korus and Joeckel, 2011). 
a complex surface formed from multiple episodes of erosion. The Ogallala Formation reaches a maximum thickness of 100 meters (m) in Antelope County (Souders and Shaffer, 1969) and pinches out in northeast Antelope County, northwest Pierce County, and southeast Knox County. The Ogallala Formation has been eroded away along Verdigre Creek in Knox County (Burchett and others, 1988; Cannia and others, 2017b; Diffendal and others, 2008). The Ogallala Formation is the primary water source for parts of the BGMA where younger, more permeable units are not present (Gosselin, 1991).

An unconformity of at least 1.5 million years separates the Ogallala Formation from the Pliocene-age Broadwater Formation (Swinehart and Diffendal, 1989). The Broadwater Formation is mapped in outcrops and in test holes from western Nebraska to the BGMA and is all part of one large fluvial deposit from an ancestral version of the Platte River (not shown on any maps; Diffendal and others, 2008). The Broadwater Formation sediments, eroded from central Wyoming and northern Colorado (not shown on any maps; Stanley and Wayne, 1972), are unevenly deposited and preserved, contain coarse sand and gravel separated by finer-grained deposits, and cover the Ogallala Formation through much of the study area. In the BGMA, Pleistoceneage fluvial deposits often overlie Pliocene-age Broadwater Formation deposits (Hobza and others, 2012; Stanton, 2013). Distinguishing the age of some of these deposits is difficult, if not impossible (Condon, 2005); as such, these deposits are referred to as Plio-Pleistocene in age by some researchers (Gosselin, 1991; Hobza and others, 2012; Stanton, 2013; Flynn and Stanton, 2018), but are called Pliocene-Pleistocene sand and gravel in this study. These fluvial deposits can be as much as $50 \mathrm{~m}$ thick and are hydrologically connected with the underlying Ogallala Formation (Gosselin, 1991; Hobza and others, 2012). Where present, Pliocene-Pleistocene sand and gravel are the primary source of irrigation water for the BGMA.

The BGMA is mantled with a complex arrangement of Quaternary deposits, consisting of loess, till, eolian sand, and alluvial deposits (Miller and Appel, 1997; Korus and others, 2012; Cannia and others, 2017a). In the northeast and eastern parts of the study area, glacial outwash deposits of sand and gravel deposited within paleovalleys are capped by glacial till and Pleistocene-age loess deposits (Korus and others, 2012; Cannia and others, 2017a; Conservation and Survey Division, University of Nebraska-Lincoln, 2019a). The distribution and thickness of glacial outwash and till deposits are important in this study because overlying till deposits can form a confining cap to underlying sand and gravel glacial outwash, preventing surface contamination into the High Plains aquifer and limiting groundwater/surface-water interaction (Cannia and others, 2017a). Modern-day streams have incised into loess and till deposits to form the landscape visible today.

\section{Groundwater Conditions}

Within the BGMA, groundwater-flow direction in the primary aquifer is variable and generally follows surface topography. In the west and northwest part of the BGMA, groundwater flows towards Verdigre Creek, Bazile Creek, and their tributaries (fig. 2). In the east and southeast, groundwater flows towards the North Fork of the Elkhorn River and its tributaries (fig. 2; Gosselin, 1991). The depth to groundwater is less than $60 \mathrm{~m}$ for the entire BGMA and the depth to groundwater is less than $30 \mathrm{~m}$ for approximately one-half of the BGMA, primarily near stream valleys (Upper Elkhorn Natural Resources District, 2016).

The streams within the BGMA are well connected with the groundwater system (Conservation and Survey Division, University of Nebraska-Lincoln, 2008) because of the sandy soils and flat topography (Upper Elkhorn Natural Resources District, 2016). The exception to this is the far northeast corner of the BGMA, which is covered with a thick cap of impermeable glacial till (fig. 1). In this far northeast corner, much of the precipitation and applied irrigation water runs off to local streams (Upper Elkhorn Natural Resources District, 2016). Verdigre Creek (fig. 1) is included with the major rivers shown in the University of Nebraska-Lincoln map (Conservation and Survey Division, University of Nebraska-Lincoln, 2008); however, Bazile Creek was omitted. The base flow patterns of Bazile Creek and other streams were simulated and analyzed by Flynn and Stanton (2018). Results indicated that Bazile Creek is a gaining stream through much of its length nearly doubling base flow from the Bazile Creek at Center, Nebr. (USGS station number 06466400) streamgage (fig. 1) to the Bazile Creek near Niobrara, Nebr. (USGS station number 06466500; not shown on any maps) streamgage, which is near the confluence of the Bazile Creek with the Niobrara River (Flynn and Stanton, 2018).

Unlike some intensely irrigated areas within Nebraska, groundwater levels in the High Plains aquifer within the BGMA have shown very little change since pre-development (McGuire, 2017; Young and others, 2016). Within the High Plains aquifer in the BGMA there are roughly three registered irrigation wells per square mile (Young and others, 2016; Upper Elkhorn Natural Resources District, 2016). Because BGMA groundwater levels have not declined despite the numerous irrigation wells, irrigation well discharge must be offset by another source of water, such as recharge. Groundwater recharge has been estimated on a regional or statewide basis for parts of the BGMA (Stanton and others, 2011; Szilagyi and Jozsa, 2013). Stanton and others (2011) reported that recharge rates for the BGMA area ranged from 0.88 to 42 centimeters per year $(\mathrm{cm} / \mathrm{yr})$ and averaged $16 \mathrm{~cm} /$ yr for 2000 to 2009. The reported rates are some of the highest for the High Plains aquifer (Stanton and others, 2011). These rates are high in part because the BGMA, which is in the northeast corner of the High Plains aquifer area, receives more precipitation and has less potential evapotranspiration than locations to the west and south (Stanton and others, 2011), 


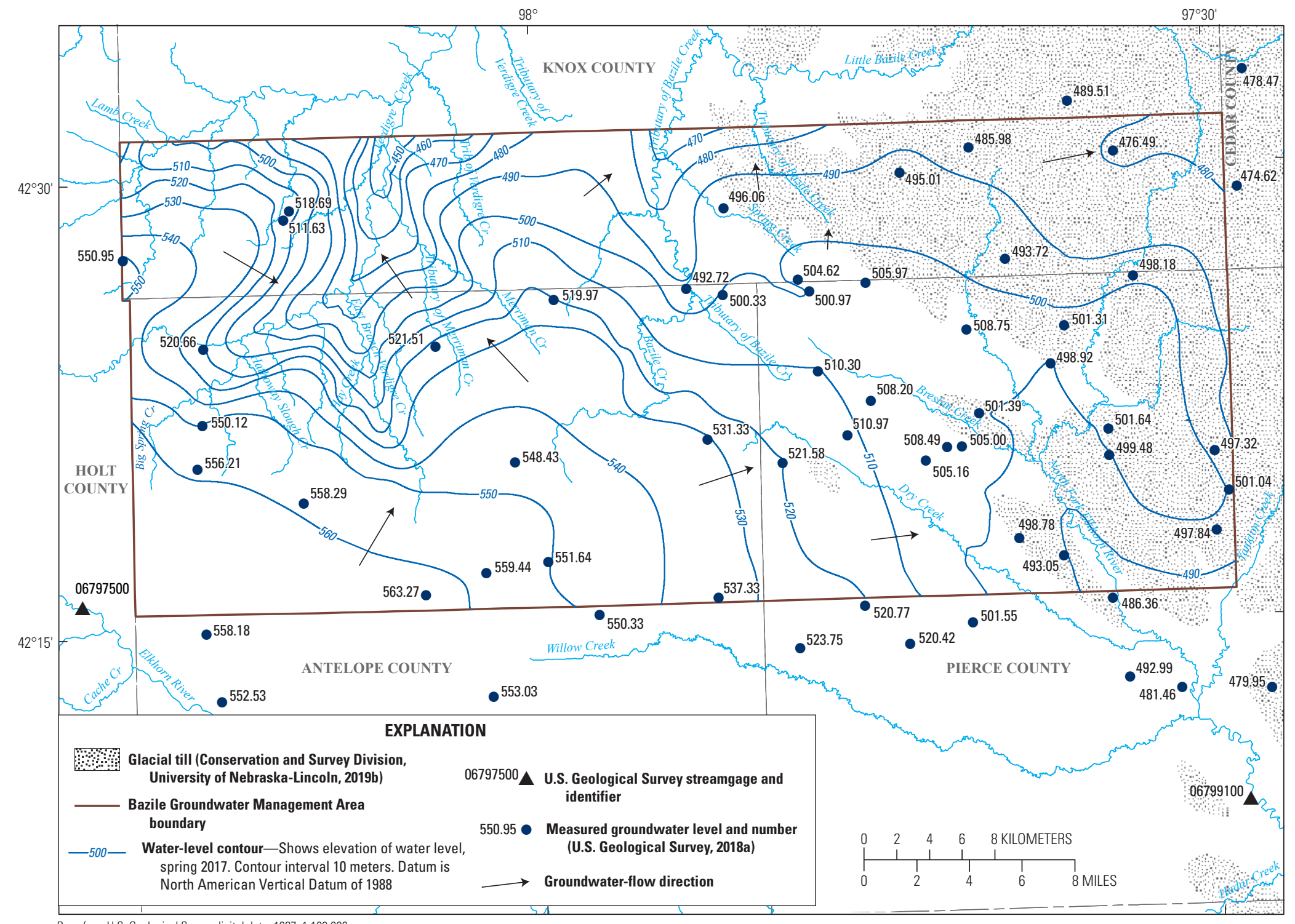

Base from U.S. Geological Survey digital data, 1987, 1:100,000

Lambert Conformal Conic projection

Standard parallels $40^{\circ} \mathrm{N}$. and $43^{\circ} \mathrm{N}$., central meridian $100^{\circ} \mathrm{W}$.

Horizontal coordinate information is referenced to the North American Datum of 1983 (NAD 83 )

Figure 2. Streams, measured groundwater levels, and interpreted water-level surface for the High Plains aquifer within the Bazile Groundwater Management Area, spring 2017. 
and has relatively permeable soils (Upper Elkhorn Natural Resources District, 2016), which reduces the loss of precipitation to surface runoff.

\section{Previous Studies}

This section of the report discusses previous studies that have documented the water-quality conditions and the geology and groundwater resources of the BGMA. Many of the data collected from these studies were used as inputs for the Geoscene3D project and are described in the "Source Data Description and Processing" subsection of this report.

\section{Water-Quality Studies}

Nitrate contamination in groundwater, which is the most common water-quality concern and drinking water impairment in Nebraska (Exner and others, 2014), has been extensively documented within the BGMA. Gosselin (1991) described the extent of nitrate contamination within the BGMA by sampling 117 irrigation wells screened in Pliocene-Pleistocene sand and gravel and in the Ogallala Formation and eight domestic wells from undifferentiated hydrostratigraphic units. At the time of sampling (summer 1989), water from approximately 25 percent of all irrigation wells exceeded the U.S. Environmental Protection Agency maximum contaminant level of 10 milligrams per liter (mg/L; U.S Environmental Protection Agency, 2018) and water from 45 percent of the wells had nitrate concentrations of between 5 and $10 \mathrm{mg} / \mathrm{L}$ (Gosselin, 1991). The lowest concentrations of nitrate were in the glaciated parts of the BGMA to the northeast. Gosselin (1991) suggested that the nitrate contamination was the result of the application of commercial fertilizers and intensive groundwater irrigation onto predominantly sandy soils that overlie a shallow water table.

A study focusing on nitrate contaminated groundwater near Creighton, Nebr., included age tracer sampling using chlorofluorocarbons (Plummer and Busenberg, 1999) and nitrogen isotopes to identify sources of nitrate contamination (Burbach and Spalding, 2000). The study identified a "plume" of nitrate contaminated groundwater that exceeded $30 \mathrm{mg} / \mathrm{L}$, which was roughly 320 hectares ( 800 acres) in size and within the 20-year travel period to the Creighton municipal wells. Isotopic analyses confirmed that the main source of nitrate was the application of commercial fertilizer to support row-crop production (Burbach and Spalding, 2000). Because groundwater samples for this study were collected from nested monitoring wells screened at various depths within the High Plains aquifer, the authors were able to document the stratification of nitrate concentration and groundwater age (Burbach and Spalding, 2000). In general, younger (shallow) groundwater had higher concentrations of nitrate. Burbach and Spalding (2000) reported that deeper parts of the High Plains aquifer were affected by upgradient sources. Vadose zone sampling indicated that nitrate is continuing to move downward beneath irrigated crop land and it was anticipated that nitrate concentrations would continue to increase or remain steady in future years (Burbach and Spalding, 2000). Detectable concentrations of deethylatrazine, the primary degradation product of atrazine (Adams and Thurman, 1991), were noted in a few monitoring wells screened in the High Plains aquifer, indicating the susceptibility of groundwater to surface contamination (Burbach and Spalding, 2000).

Groundwater was sampled more recently from the High Plains aquifer at 52 locations across the BGMA to evaluate the effectiveness of groundwater management plans and best management practices (Snow and Miller, 2018). Wells were sampled in fall of 2015 and summer of 2016 for nitrogen concentration and nitrate isotopes. Of the 52 wells sampled, 26 were wells that Burbach and Spalding (2000) sampled for nitrate and nitrate isotopes. An additional 11 samples were collected in 2017 for dissolved gases, age tracers, and isotope analyses (Snow and Miller, 2018). Interpreted groundwater ages and nitrate concentrations indicated that even if a substantial reduction in nitrate loading were to immediately occur, it would still require 15 to 30 years for nitrate concentrations in groundwater to decrease. Insights gained from previous work have provided valuable information to enable managers to communicate the concept of lag time between groundwater management decisions and decreases of nitrate in groundwater or other expected positive outcomes (Snow and Miller, 2018).

Additional groundwater-quality studies have been completed that have focused on characterizing water quality for larger areas that have included part of the BGMA. In 2003 and 2007, the USGS completed two separate data collection efforts to determine vertical gradients in nitrate and groundwater age. Nested monitoring wells were screened at different depths and hydrostratigraphic units were sampled for the Upper Elkhorn NRD in 2003 and the Lower Elkhorn NRD in 2007. Within the Upper Elkhorn NRD, 11 wells were sampled at four locations within the BGMA, and within the Lower Elkhorn NRD, four wells were sampled at two locations within the BGMA. Waterquality and age tracer data are stored in the USGS National Water Information System (NWIS) database (U.S. Geological Survey, 2018a). For most aquifers, nitrate concentrations decrease, and groundwater ages increase with depth (Kazemi and others, 2006). Groundwater in the deepest well in each well nest was found to be pre-modern. The nitrate concentration of pre-modern groundwater was less than background concentrations of $2 \mathrm{mg} / \mathrm{L}$ (Mueller and Helsel, 1996). For this report, pre-modern is defined as water that has recharged before 1950 , which is roughly the time that commercially available fertilizers were first applied within the BGMA.

One study, which was part of the USGS National WaterQuality Assessment program, was designed to determine the effect of row-crop production on water quality in shallow groundwater beneath glacial till by sampling a network of 28 monitoring wells in 2003 (Stanton and others, 2007b). Age tracer and nutrient sampling results indicated that shallow groundwater was recharged less than 30 years ago, and three samples collected within the BGMA indicated that water was 20 years old or less (Hinkle and others, 2010; Stanton and 
others, 2007b). The median nitrate concentration for wells within the glacial till network was $9.53 \mathrm{mg} / \mathrm{L}$ and the median nitrate concentration for the three wells within the BGMA was $8.9 \mathrm{mg} / \mathrm{L}$ (Stanton and others, 2007b).

The lithologic controls on groundwater recharge were studied by Gates and others (2014) for incised glacial terrain in eastern Nebraska. Although Gates and others (2014) focused on groundwater recharge rates from the perspective of water quantity, the main points of the paper can be evaluated in terms of solute and contaminant movement and groundwater vulnerability. Modern streams have incised glacial till deposits in eastern Nebraska, resulting in the current topography, where till thicknesses can range up to $30 \mathrm{~m}$ (Gates and others, 2014). Gates and others (2014) stated that lower rates of groundwater recharge are associated with the thickest sections of clay-rich till in the unsaturated zone. As such, areas covered with a thick cap of glacial till have slower rates of infiltration through the unsaturated zone (less than $1 \mathrm{~cm} / \mathrm{yr}$ ) and are less susceptible to groundwater contamination (Gates and others, 2014).

\section{Geologic and Groundwater Studies}

Many geologic and groundwater studies have included all or parts of the BGMA, including Condra and Reed (1943), Souders and Shaffer (1969), Stanley and Wayne (1972), Gutentag and others (1984), Helgesen and others (1993), Miller and Appel (1997), McGuire and Peterson (2008), Hobza and others (2012), Houston and others (2013), Korus and others (2013), and Stanton (2013). Geologic bedrock maps covering the BGMA have been published by Burchett and others (1988) and Diffendal and others (2008) at the 1:250,000 scale. In addition to surficial geology, Diffendal and others (2008) mapped subcropping geologic units and provided a thorough discussion of the geologic history for the western part of the BGMA. Test-hole drilling with mud-rotary drilling equipment has been an integral part of groundwater and geologic studies in Nebraska for many years (Hobza and others, 2012). Countywide test-hole log books have been published for the BGMA; however, the most comprehensive dataset can be found in Conservation and Survey Division, University of Nebraska-Lincoln (2019a). Using primarily test-hole data, Korus and others (2012) published cross-sections traversing part of the BGMA.

Starting in 2006, the Eastern Nebraska Water Resources Assessment (ENWRA) began hydrogeological studies in coordination with six NRDs, including the Lower Elkhorn NRD and Lewis and Clark NRD, to develop a geologic framework and water budget for the glaciated parts of eastern Nebraska (Divine and others, 2009). Since 2007, AEM geophysical surveys have been a focus of the ENWRA group to map aquifers and to aid in the assessment of groundwater resources. AEM surveys began in the BGMA in 2014 when a large reconnaissance survey mapped much of the northern portion of the glaciated area to create a regional hydrogeologic framework (Carney and others, 2015a). Additional AEM surveys were completed in 2014 and 2016 (Carney and others, 2015a; Exploration Resources International, 2015; Cannia and others, 2017a, b) and are described in detail in the "Airborne Electromagnetic Surveys" subsection of this report.

\section{Hydrologic Data Compilation and Analysis}

This section of the report describes the procedures used to assemble geologic, geophysical, water-quality, and waterlevel data for the BGMA from publicly available, qualityassured sources. These data were incorporated for use within the Geoscene3D software package where users can download hydrogeologic data from the Nebraska Geocloud, which is a cloud-based online geodatabase. Geoscene3D provides an integrated, 3D geological modeling environment, which combines spatial data in GIS format, lithologic and stratigraphic data from test holes, and AEM or other geophysical data.

\section{Source Data Description and Processing}

This section of the report describes the procedures and steps taken to assemble and process publicly available, quality-assured hydrogeologic data for use within the Geoscene3D software package. Within the Geoscene3D program, all datasets are required to be in the same horizontal and vertical spatial reference system. A projected coordinate system was selected as the horizontal spatial reference system to minimize scale distortions (Esri, 2019). Minimizing scale distortions is particularly important if the user wishes to calculate aquifer or formation volumes from regional 3D geologic models. The native or original coordinate systems for datasets described herein were typically given in latitude and longitude. All data served on the Nebraska Geocloud were projected to the Nebraska State Plane meters coordinate system referenced to the North American Datum of 1983 (European Petroleum Survey Group [EPSG 32104). The selected vertical spatial reference system was the North American Vertical Datum of 1988 (NAVD 88).

For any given project, Geoscene3D uses a terrain surface as its primary vertical datum from which subsurface data will be fixed to. A digital elevation model was created for the study area by downloading an Esri raster (Esri, 2019) from the National Elevation Dataset USGS National Map web page (U.S. Geological Survey, 2018b). The grid cell size of the raster was 1 arcsecond, which is approximately $30 \mathrm{~m}$. Finerresolution elevation datasets are available for the BGMA but considering the low relief of the area and the coarse vertical resolution of some datasets, the 1-arcsecond raster was adequate. The raster file was clipped to the study area boundary and converted to an ascii file using the ArcGIS clip and raster conversion tools (Esri, 2019) for use in Geoscene3D. 
Most datasets added to the Geoscene3D project were characterized as point data with unique horizontal coordinates, including test-hole, water-level, or water-quality data. The horizontal coordinates were used to extract a surface elevation for each point from the project terrain surface using ArcGIS (Esri, 2019). Other basic data changes, such as converting well screen depths from feet to meters below land surface or removing unnecessary columns from native datasets, were completed in Microsoft Excel. Datasets were saved as comma delimited text files for import into Geoscene3D.

\section{Airborne Electromagnetic Surveys}

The use of AEM geophysical surveys to map aquifers and aid in the assessment of groundwater resources is an increasingly common approach used by water managers and scientists (Smith and others, 2008, 2011; Hobza and others, 2014; Carney and others, 2015a, b; Exploration Resources International, 2015; Korus and others, 2016; Cannia and others, 2017a, b). AEM surveys characterize variations in the electrical properties of earth materials - in particular, electrical resistivity in units of ohm-meters, or its reciprocal, electrical conductivity in units of siemens per meter. Electrical resistivity measurements are sensitive to water content and quality, and changes in lithology. In the absence of clay or other conductive material (such as dissolved solids in pore water), lower electrical resistivity corresponds to higher porosity, smaller grain size, or both because of the greater surface area associated with fine particles that promotes the transmission of electrical current (Biella and others, 1983; Kwader, 1985); higher resistivity is associated with coarse-grained deposits, such as alluvial sand and gravel or sandstone. As such, changes in electrical resistivity can be correlated with geologic units at depth using lithologic logs to provide verification of subsurface geology. More information regarding the electrical properties of differing types of rocks can be found in Keller (1987) and Palacky (1987).

AEM systems provide a measure of the subsurface resistivity by transmitting electromagnetic signals into the earth using two types of systems: time-domain electromagnetic (TDEM) and frequency-domain electromagnetic. Comparatively, TDEM systems can image deeper within the subsurface, but at the cost of decreased near-surface resolution (Abraham and others, 2012; Korus and others, 2016). All AEM data collected within the BGMA were collected with TDEM systems. To collect resistivity data, TDEM systems pass a current through a wire loop, which, as explained by Ampere's law, generates a primary magnetic field (Fitterman and Labson, 2005). The primary current is rapidly turned off, thereby causing a time-varying change in magnetic flux, which induces voltages, and hence eddy currents, in conductive bodies, according to Faraday's law of induction (Fitterman and Labson, 2005). Secondary magnetic fields are produced by the decay of these subsurface eddy currents and typically are measured with a receiver loop. An apparent resistivity for a sounding is calculated from the measured voltage at the receiver coil and the time elapsed after primary current was turned off (Hobza and others, 2012). The sounding is numerically inverted to produce a depth-dependent model of the subsurface resistivity (Carney and others, 2015a). More information regarding the TDEM method, data collection, and numerical inversion is available in Fitterman and Labson (2005) and Cannia and others (2017a).

AEM surveys began in the BGMA in 2014 when a large reconnaissance survey mapped much of the northern portion of the ENWRA, including parts of the Lewis and Clark and Lower Elkhorn NRDs (fig. 3A; table 2; Carney and others, 2015a). The primary goal of the reconnaissance AEM survey was to develop a regional hydrogeologic framework. The SkyTEM 508 system, which can collect data to a depth of nearly $500 \mathrm{~m}$ below land surface, was chosen for this reconnaissance survey to primarily map water-bearing Cretaceous-age units and identify possible secondary water sources (Carney and others, 2015a). In a separate but related effort, additional AEM survey lines were collected in 2014 along north-south and east-west gridlines approximately 5 kilometers $(\mathrm{km} ; 3$ miles [mi]) apart in the southeastern part of the BGMA within the Lower Elkhorn NRD (fig. 3A; table 2; Exploration Resources International, 2015).

The remainder of the BGMA was surveyed in July 2016 when 1,036 line-kilometers (644 line-miles) of data (Cannia and others, 2017a) were collected west of the ENWRA area including parts of the Lower Niobrara and Upper Elkhorn NRDs (fig. $3 A$ ). AEM data were collected along north-south and east-west gridlines approximately $5 \mathrm{~km}(3 \mathrm{mi})$ apart and two "block" flights (fig. $3 A$ ) near the Creighton Water System (fig. $3 B$ ) and the West Knox Rural Water System (fig. 3C). The densely spaced flight lines within the block flight areas were collected to provide sufficient information to estimate the volume of water in storage (Cannia and others, 2017b). The Lower Elkhorn NRD contracted a portion of the 5-km (3-mi) grid AEM survey lines (Cannia and others, 2017b) covering the eastern part of the BGMA (fig. $3 A$ ). For these surveys, the SkyTEM 304M system was used. The SkyTEM 304M system is only able to collect data to a depth of about $300 \mathrm{~m}$ but with better vertical resolution compared to the SkyTEM 508 system (Cannia and others, 2017a). Flight and survey planning, AEM survey instrumentation, calibration and data collection procedures, data processing, and inversion are described in further detail in Carney and others (2015a) and Cannia and others (2017a).

Cannia and others (2017a) included interpretations of all AEM data collected within the BGMA. Cannia and others (2017a) also included resistivity data from all inverted AEM profiles, elevation of interpreted geologic surfaces, and other supporting information. An inverted AEM profile consists of many soundings collected approximately $3 \mathrm{~m}$ apart, each with 29 resistivity values corresponding to a depth interval of increasing thickness. In addition to resistivity value, an interpreted sediment category (nonaquifer, marginal aquifer, aquifer, and coarse aquifer material) is given to resistivity ranges. Carney and others (2015a) developed a relation between 
Table 2. Data sources and supporting information used in Geoscene3D project.

[USGS, U.S. Geological Survey; NA, not applicable; NWIS, National Water Information System; CSD, University of Nebraska-Lincoln Conservation and Survey Division; NDNR, Nebraska Department of Natural Resources; ENWRA, Eastern Nebraska Water Resources Assessment; LENRD, Lower Elkhorn Natural Resources District; BGMA, Bazile Groundwater Management Area]

\begin{tabular}{|c|c|c|c|c|c|}
\hline Dataset category & Data source or publication & $\begin{array}{l}\text { Data collec- } \\
\text { tion period }\end{array}$ & $\begin{array}{l}\text { Number of } \\
\text { samples, } \\
\text { water levels, } \\
\text { logs, or line- } \\
\text { miles }\end{array}$ & $\begin{array}{l}\text { Data collected or } \\
\text { interpreted }\end{array}$ & Online source (if available) \\
\hline \multicolumn{6}{|c|}{ Water quality } \\
\hline USGS historical water quality & USGS, 2018a & $1953-2015$ & 59 & $\begin{array}{l}\text { nutrients, field prop- } \\
\text { erties, major ions, } \\
\text { others }\end{array}$ & https://doi.org/10.5066/F7P55KJN \\
\hline Agrichemical Clearinghouse & $\begin{array}{l}\text { University of Nebraska- } \\
\text { Lincoln, } 2019\end{array}$ & 2016 & 409 & nitrate & https://clearinghouse.nebraska.gov/Clearinghouse.aspx \\
\hline $\begin{array}{l}\text { Agrichemical Clearinghouse results } \\
\text { for LENRD irrigation wells }\end{array}$ & $\begin{array}{l}\text { University of Nebraska- } \\
\text { Lincoln, } 2019\end{array}$ & 2015 & 246 & nitrate & https://clearinghouse.nebraska.gov/Clearinghouse.aspx \\
\hline \multirow{5}{*}{ Age tracers } & Burbach and Spalding, 2000 & $1997-2000$ & 14 & age tracers, nitrate & NA \\
\hline & Snow and Miller, 2018 & 2017 & 6 & age tracers, nitrate & NA \\
\hline & USGS, 2018a & 2003 & 11 & age tracers, nitrate & https://doi.org/10.5066/F7P55KJN \\
\hline & USGS, 2018a & 2007 & 4 & age tracers, nitrate & https://doi.org/10.5066/F7P55KJN \\
\hline & $\begin{array}{l}\text { Stanton and others, 2007b; } \\
\text { USGS, 2018a }\end{array}$ & 2003 & 3 & age tracers, nitrate & https://doi.org/10.5066/F7P55KJN \\
\hline \multirow[b]{2}{*}{ Pesticides } & USGS, 2018a & $2002-05$ & 3 & pesticides & https://doi.org/10.5066/F7P55KJN \\
\hline & $\begin{array}{l}\text { University of Nebraska- } \\
\text { Lincoln, } 2019\end{array}$ & $1991-97$ & 14 & pesticides & https://clearinghouse.nebraska.gov/Clearinghouse.aspx \\
\hline \multicolumn{6}{|c|}{ Groundwater level } \\
\hline Water-levels in USGS NWIS & USGS, 2018a & $\begin{array}{l}\text { February to } \\
\text { June } 2017\end{array}$ & 158 & groundwater level & $\begin{array}{l}\text { https://doi.org/10.5066/F7P55KJN (see table } 3 \text { for site } \\
\text { numbers) }\end{array}$ \\
\hline CSD 1995 water-level map & $\begin{array}{l}\text { Summerside and others, } \\
2001\end{array}$ & 1995 & NA & groundwater level & NA \\
\hline Water levels from recorder wells & USGS, 2018a & $2013-18$ & 27 & $\begin{array}{l}\text { Continuous ground- } \\
\text { water level }\end{array}$ & $\begin{array}{l}\text { https://doi.org/10.5066/F7P55KJN (see table } 4 \text { for site } \\
\text { numbers) }\end{array}$ \\
\hline \multicolumn{6}{|c|}{ Geologic } \\
\hline CSD test holes (lithology) & $\begin{array}{l}\text { Conservation and Survey } \\
\text { Division, University of } \\
\text { Nebraska-Lincoln, 2019a }\end{array}$ & multiple years & 59 & lithology & $\begin{array}{l}\text { http://snr.unl.edu/data/geologysoils/NebraskaTestHole/ } \\
\text { NebraskaTestHoleIntro.aspx }\end{array}$ \\
\hline CSD test holes (stratigraphy) & $\begin{array}{l}\text { Conservation and Survey } \\
\text { Division, University of } \\
\text { Nebraska-Lincoln, 2019a }\end{array}$ & multiple years & 51 & stratigraphy & $\begin{array}{l}\text { http://snr.unl.edu/data/geologysoils/NebraskaTestHole/ } \\
\text { NebraskaTestHoleIntro.aspx }\end{array}$ \\
\hline
\end{tabular}


Table 2. Data sources and supporting information used in Geoscene3D project.-Continued

[USGS, U.S. Geological Survey; NA, not applicable; NWIS, National Water Information System; CSD, University of Nebraska-Lincoln Conservation and Survey Division; NDNR, Nebraska Department of Natural Resources; ENWRA, Eastern Nebraska Water Resources Assessment; LENRD, Lower Elkhorn Natural Resources District; BGMA, Bazile Groundwater Management Area]

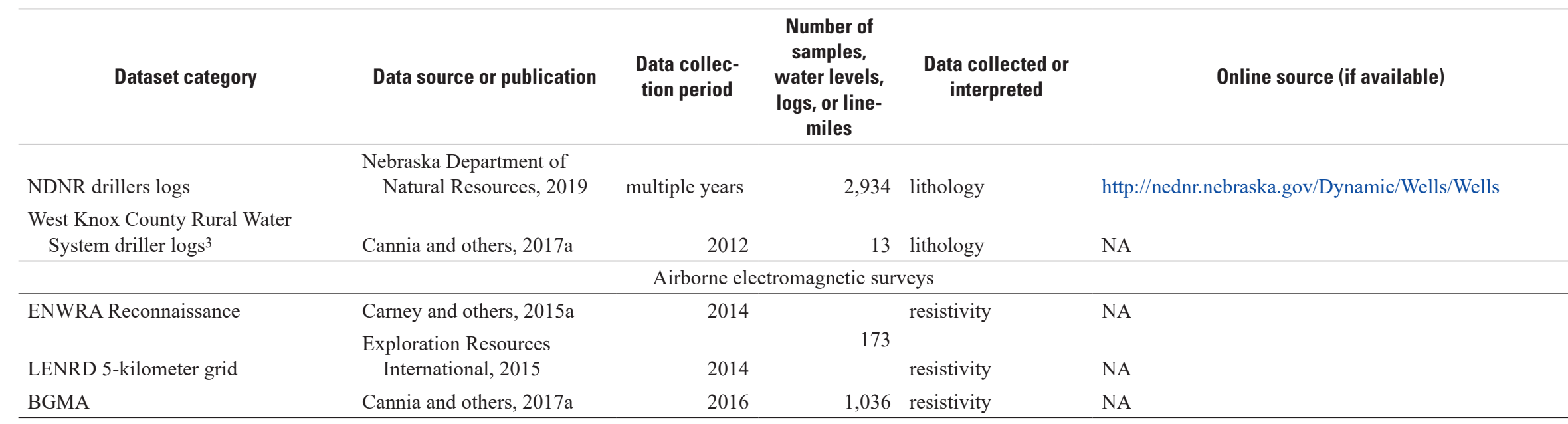

${ }^{1}$ Of the 61 water levels available in USGS (2018a), 58 were used.

${ }^{2} \mathrm{Of}$ the 15 continuous groundwater level records examined, seven are stored in USGS (2018a).

${ }^{3}$ Cannia and others (2017a) provided contractor furnished logs from West Knox Rural Water system. 


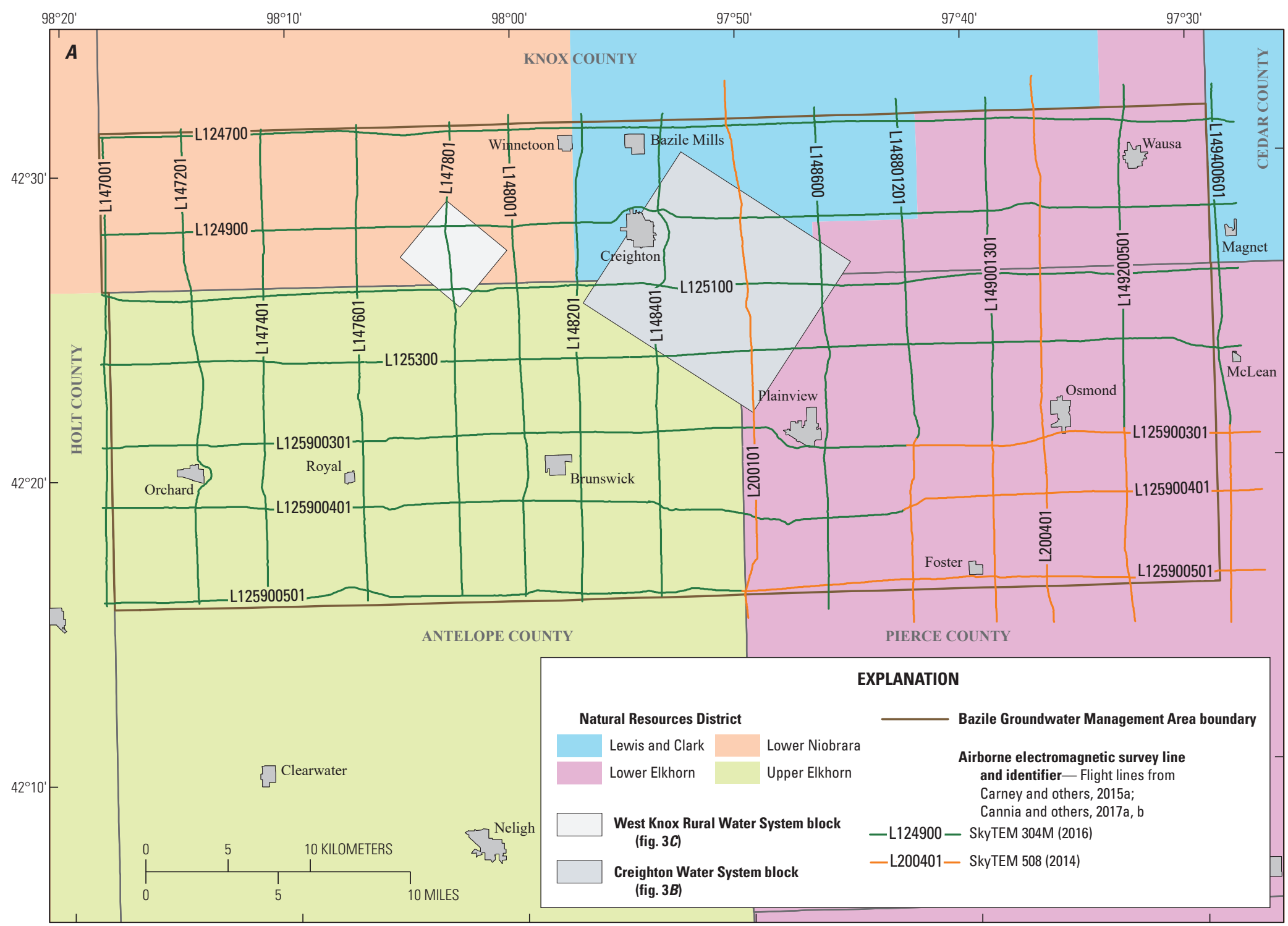

Base from U.S. Geological Survey digital data, 1987, 1:100,000

Lambert Conformal Conic projection

Standard parallells $40^{\circ} \mathrm{N}$. and $43^{\circ} \mathrm{N}$., central meridian $100^{\circ} \mathrm{W}$.
Horizontal coordinate information is referenced to the North American Datum of 1983 (NAD 83)

Figure 3. Airborne electromagnetic (AEM) survey lines collected within the Bazile Groundwater Management Area. $A$, flight line numbers, year of AEM data collection, and the outline of two areas with denser AEM data. B, Creighton Water System flight block. $C$, West Knox Rural Water System flight block. 


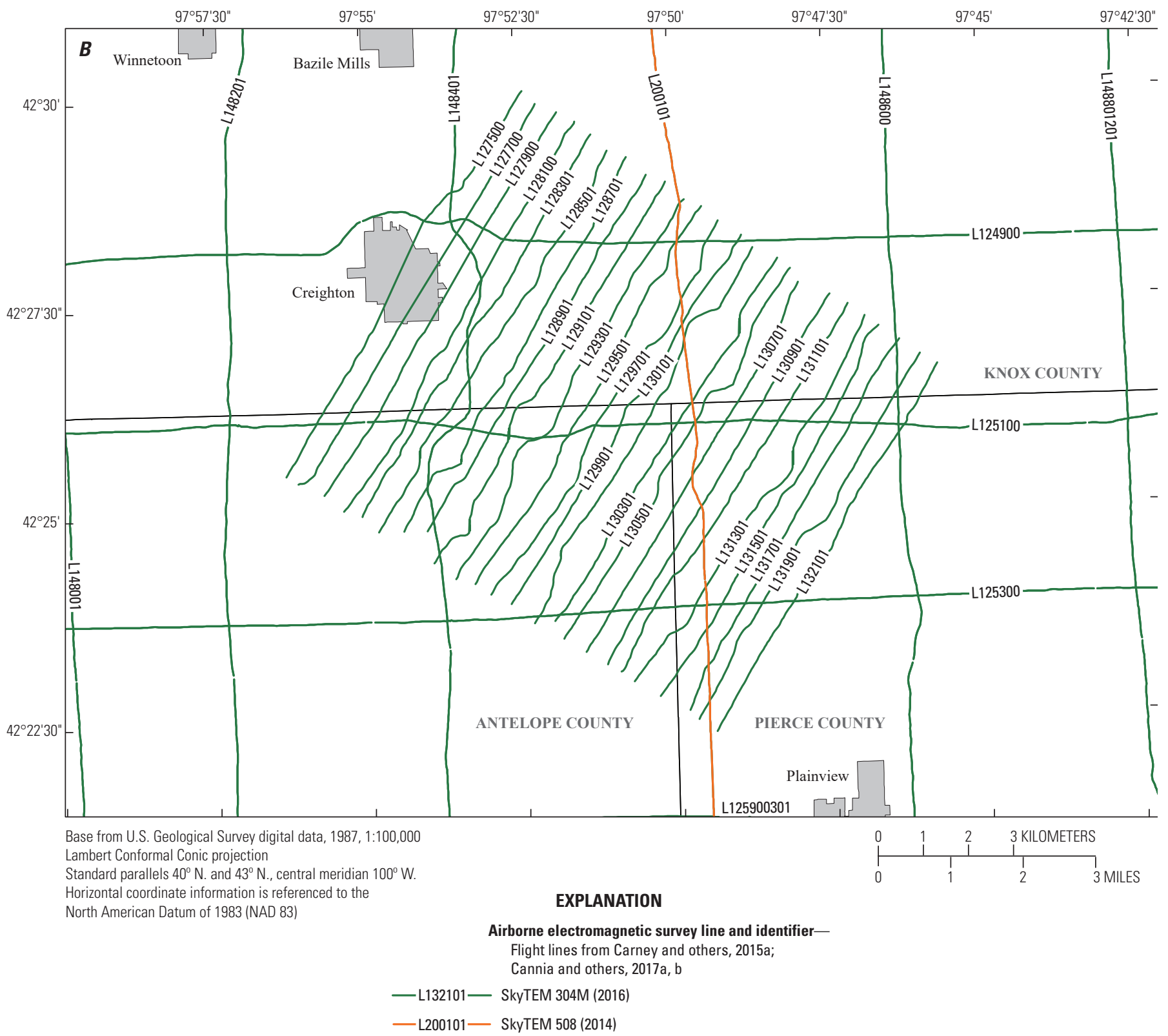

Figure 3. Airborne electromagnetic (AEM) survey lines collected within the Bazile Groundwater Management Area. $A$, flight line numbers, year of AEM data collection, and the outline of two areas with denser AEM data. $B$, Creighton Water System flight block. C, West Knox Rural Water System flight block. - Continued

the resistivity value (given in ohm-meters) and the qualitative characterization of the sediment for the Quaternary- and Tertiary-age sediments. This system was adopted by Cannia and others (2017a) for describing the Quaternary- and Tertiary-age sediments underlying the BGMA. The four major categories and their resistivity ranges are nonaquifer (less than $12 \mathrm{ohm}$-meters [ohm-m]), marginal aquifer (12 to $20 \mathrm{ohm}-\mathrm{m}$ ), aquifer (20 to $50 \mathrm{ohm}-\mathrm{m}$ ), and coarse aquifer material (greater than $50 \mathrm{ohm}-\mathrm{m})$.
AEM data from surveys within the BGMA, which were imported into a Geoscene3D project, were quality assured by examining the intersection of AEM profiles to ensure consistent resistivity patterns. Because two different AEM systems (SkyTEM 508 and SkyTEM 304M) were used and the databases were merged rather than reinverted, the intersection of those profiles varies slightly because the depth of investigation and the variable thickness of resistivity rows for each sounding. 


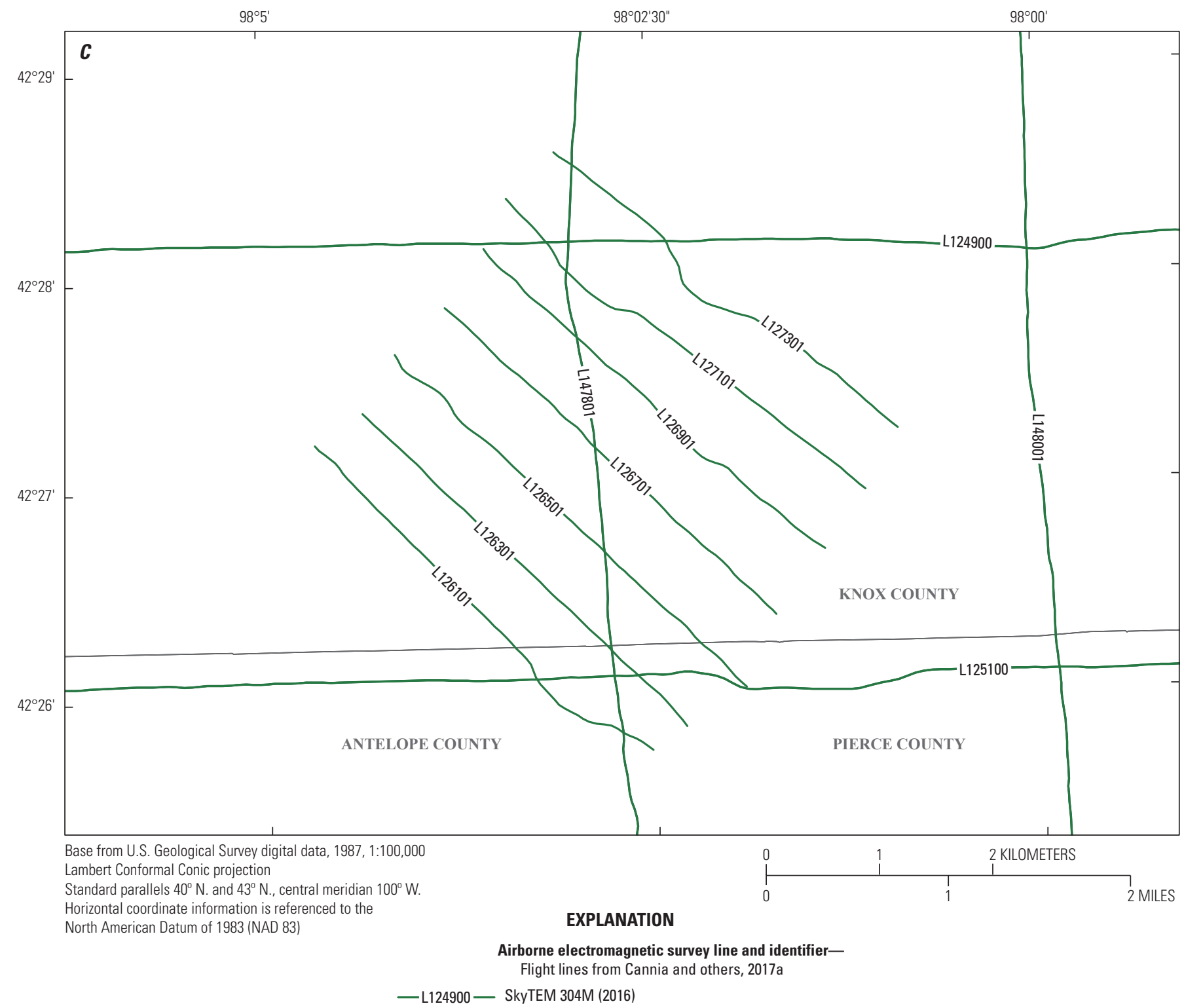

Figure 3. Airborne electromagnetic (AEM) survey lines collected within the Bazile Groundwater Management Area. $A$, flight line numbers, year of AEM data collection, and the outline of two areas with denser AEM data. $B$, Creighton Water System flight block. C, West Knox Rural Water System flight block.-Continued

Other quality-assurance checks were performed after the AEM data were imported into Geoscene3D. The depth of investigation (DOI) for each sounding in an AEM profile, calculated using the approach presented in Christiansen and Auken (2012), was provided by Cannia and others (2017a) as part of the supplemental data released with their report. The DOI provides an estimate of the maximum model depth as was constrained by the measured data (Cannia and others, 2017a). These DOI estimates are based on a specified sensitivity threshold and are viewed as relative, rather than absolute. Simply stated, less confidence is placed on inverted resistivity data below the DOI. In general, the DOI was well below the base of the High Plains aquifer (top of the Pierre Shale or Niobrara Formation); however, the DOI was near or above the base of the aquifer in areas covered with a thick cap of glacial till. 


\section{Test-Hole Logs and Well Drillers' Logs}

Ground-truth information, in the form of test-hole logs and drillers' logs, is essential to constraining geophysical models and interpreting AEM data. All geophysical methods, including TDEM, exhibit a degree of nonuniqueness where, in the absence of ground-truth information, multiple models or interpretations can fit or honor the measured geophysical data. Available test-hole logs and drillers' logs are needed during modeling and inversion of AEM data to provide guidance during interpretation (Cannia and others, 2017a).

Ground-truth information was assembled from several sources. A total of 59 CSD test holes were drilled within and near the BGMA, of which 51 contain interpreted stratigraphic contacts (fig. 4; table 2; Conservation and Survey Division, University of Nebraska-Lincoln, 2019a). CSD test holes contain detailed lithologic information and are regarded as the most reliable and consistent source for geologic information (fig. 4). Cannia and others (2017a) also utilized lithologic information from 2,934 drillers' logs from the Nebraska Department of Natural Resources registered well database to supplement the test-hole logs (fig. 4; table 2; Nebraska Department of Natural Resources, 2019). The locations of the registered wells were verified, and lithologic descriptions were summarized into 23 generalized lithologic categories by a licensed professional geologist (Cannia and others, 2017a). Driller's logs from the Nebraska Department of Natural Resources database provide valuable information but are generally considered to be a less reliable source of lithologic information compared to CSD test-hole logs, in part because the drillers, who describe the lithology, typically are not professional geologists and accurate lithologic description is often secondary to drilling and well installation. For this report, no further quality-control checks were performed on the test-hole and drillers' logs, and all logs were imported as reported from Cannia and others (2017a).

\section{Water-Quality Data}

Water-quality data are routinely collected by several Federal, State, and local agencies within the BGMA. Routine groundwater sampling is part of current groundwater monitoring programs for the four NRDs within the BGMA; however, there is a lack of uniformity in the timing and location of groundwater samples. Groundwater sample results collected by NRDs are submitted to the quality-assessed agrichemical contaminant database for Nebraska groundwater (University of Nebraska-Lincoln, 2019; hereafter referred to as the "agrichemical clearinghouse"). The agrichemical clearinghouse is focused on providing sampling results for the nutrients and pesticides, which are the primary agricultural contaminants. Supporting geochemical information, such as dissolved oxygen, water temperature, specific conductance, and water levels, is not reported with the sample result in the
BGMA area. Currently (2020), approximately 8,000 nitrate results have been reported in the BGMA area, and the latest sampling results were from 2017.

The USGS and University of Nebraska-Lincoln also have collected water-quality data in focused studies that included the BGMA area. The results from these previous studies were typically uploaded into the agrichemical clearinghouse (University of Nebraska-Lincoln, 2019). These wells generally are not resampled and, therefore, the sample results only represent groundwater-quality conditions at a single point in time; however, supporting information such as field properties, including dissolved oxygen, provide a more complete characterization of the geochemical conditions. A total of 59 samples collected by the USGS, dating back to 1953, were assembled from the NWIS database (U.S. Geological Survey, 2018a). Of the USGS samples included, 35 have been collected since 2000. One sample was collected before 1960, which is close to when use of widespread commercial fertilizers began (Mueller and Helsel, 1996).

As highlighted in the "Previous Studies" subsection, groundwater-quality studies by the USGS and University of Nebraska-Lincoln have objectives beyond characterizing nitrate concentrations in groundwater. Age tracer studies completed by Burbach and Spalding (2000), Stanton and others (2007b), and Snow and Miller (2018) were assembled for inclusion in Geoscene3D. Although nitrate is the primary agricultural contaminant of concern, some groundwater samples also have been analyzed for pesticides and their degradants. All available pesticide data were examined from the USGS NWIS database (U.S. Geological Survey, 2018a) and the agrichemical clearinghouse (University of NebraskaLincoln, 2019). Pesticide data were available for 122 wells in the agrichemical clearinghouse and 6 wells in the USGS NWIS database. Detectable concentrations of pesticides were found in a total of 28 samples from 17 wells (table 2; fig. 4); 14 wells from the agrichemical clearinghouse and 3 from the USGS NWIS database.

Pesticide sampling data can provide additional information about the time scales of recharge processes and the residence time within the vadose zone. Using the sampling date and the pesticide registration year, an apparent groundwater age can be inferred. For example, if a sample collected in 1995 had a detectable concentration of deethylatrazine, and atrazine was registered for commercial use in 1958, then it can be inferred that the sampled groundwater is less than 38 years old. Although the calculated apparent age using this method is not as precise as the age determined with environmental tracers, the vulnerability of aquifers to surface contamination and the time scales of recharge processes can be assessed. Some wells within the BGMA had multiple detections of pesticides from a single sample or multiple detections of the same pesticide from repeated sampling. For each well, the youngest calculated apparent groundwater age was chosen for inclusion in Geoscene3D. 


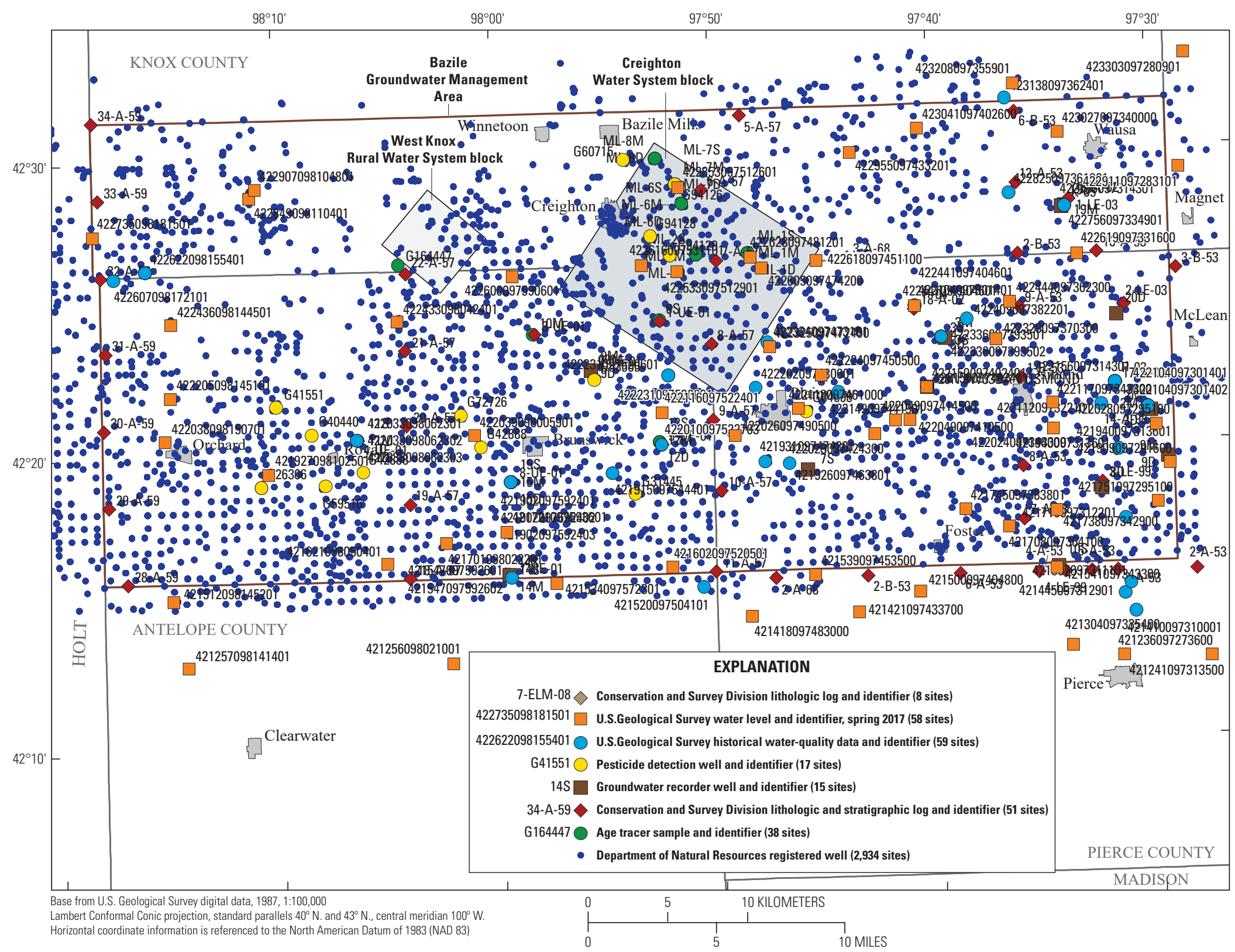

Figure 4. Map showing selected test-hole, water-level, and water-quality data assembled and imported into the Geoscene3D project. This file is layered; click the Layers icon to view hidden datasets. 


\section{Discrete and Continuous Water-Level Data}

Discrete and continuous water-level data have been an integral part of groundwater monitoring activities for the several local, State, and Federal agencies operating within the BGMA. Much of the available data are collected by the CSD, USGS, and four NRDs. The NRDs typically collect discrete (or single) water levels from many wells one time during the spring and fall each year (where spring is considered to be February to early June, and fall is considered to be September to December). These water levels are reported to the USGS for inclusion into the NWIS database for wells (U.S. Geological Survey, 2018a). The USGS further relays all these water levels to the CSD, University of Nebraska-Lincoln, for inclusion in a CSD database (Aaron Young, Conservation and Survey Division, University of Nebraska-Lincoln, written commun., January 2020). Discrete water levels from the spring are collected to assess the change in water level from year to year prior to the start of groundwater irrigation each year. Discrete water levels from the fall are used to assess water levels after groundwater irrigation pumping has ceased.

Discrete water levels collected from the High Plains aquifer by the four NRDs, the CSD, and the USGS were downloaded from the NWIS database (U.S. Geological Survey, 2018a). Currently (2020), the most recent, complete data available were the spring 2017 water levels. There were water levels from 61 wells from spring 2017; these wells are generally evenly distributed across the BGMA. However, there were insufficient water-level data available to characterize the spring 2017 water-table elevation in the northwest part of the BGMA, where Verdigre Creek and its tributaries have incised steep drainages into the Pierre Shale.

Often, water-level maps, presented as water-level elevation contours, are derived from discrete water-level data. Supporting data, such as stream elevations, and hydrologic intuition are used to modify these contours over the area of interest. Geoscene3D uses an interpolated user-defined water-level surface over the entire study area to draw or display the water level along AEM profiles, which are not adjacent to wells. Published maps of the water-table elevation surface from 1995 (Summerside and others, 2001) were used by Cannia and others (2017a) for their hydrogeologic interpretation. Published maps of 1995 water-level elevation contours had been available in a digital format but are no longer publicly available, in part because of inconsistencies that stem from an assumption that all streams were well connected hydrologically with the principal aquifer, which is not always the case, particularly in glaciated areas within eastern Nebraska (A.R. Young, University of NebraskaLincoln Conservation and Survey Division, oral commun., December 2019). However, because groundwater and surface water are well connected within the BGMA, particularly along Verdigre Creek (Conservation and Survey Division, University of Nebraska-Lincoln, 2008), for this study, it is assumed that the 1995 water-table elevation surface map is a reasonable estimate of this surface.
In an effort to create an updated water-level elevation surface map, which is representative of the entire BGMA, the 1995 water-level elevation contours first were compared to discreet spring 2017 water levels by importing the contour and point datasets into ArcGIS as shapefiles (Esri, 2019). In general, water levels from both datasets were similar; however, three water levels from shallow wells located within the glaciated part of the BGMA were excluded from the spring 2017 discrete water-level measurements (table 3). The water levels measured in each of these three wells were much shallower when compared to the 1995 statewide water-level elevation contours, most likely because these wells are screened in a perched aquifer; therefore, these three water levels most likely represent localized conditions, and not the regional groundwater-flow system. The 58 discrete water levels used to create the water-level elevation surface are listed in table 3 and shown in figure 2. Using the editor tool in ArcGIS, the 1995 water-level elevation contours were modified to be consistent with the spring 2017 water-level data. The contours only required minor modifications, primarily in the glaciated, northeastern part of the BGMA. The 1995 water-level elevation contours were the only source of water-level elevation information in the areas with high topographic relief near the northwest part of the BGMA along Verdigre Creek and near the northern border of the BGMA along Bazile Creek. Using the modified water-level elevation contours and the 2017 discrete water-level measurements, the Topo2Raster tool (Esri, 2019) was used to create water-level elevation surface raster, in feet above NAVD 88. The raster calculator (Esri, 2019) was used to convert the water-level elevation surface to meters above NAVD 88. The raster to ascii tool (Esri, 2019) was used to create a water-level elevation surface raster compatible for use in Geoscene3D. The water-level elevation surface raster also is available as a USGS data release (Hobza, 2020).

Continuous water levels are collected as part of routine groundwater monitoring plans of the USGS and the four NRDs within the BGMA. The Lower Elkhorn, Upper Elkhorn, and Lewis and Clark NRDs have collected continuous waterlevel data for years to assess the effectiveness of their own groundwater management plans. Groundwater-level recorder data are typically recorded with self-logging transducers where NRD staff can move the transducer from one monitoring well to another, which gives NRDs the ability to monitor areas of concern with limited resources. Periodically, NRD staff and the USGS also manually measure water levels in these wells using either a steel or electric tape to verify the accuracy of the recorded data. For this report, 15 continuous water-level records were examined and evaluated (table 4; available at https://doi.org/10.3133/sir20205113). Geoscene3D is not a tool used to interpret water-level hydrographs; however, interpreting water-level patterns in response to precipitation, pumping, and interaction with surface water has offered clues in this study to the connectivity of groundwater to surface water, vulnerability of groundwater to surface contamination, 
Table 3. Measured water levels in wells completed in the High Plains aquifer within the Bazile Groundwater Management Area, spring 2017.

[Data are available in U.S. Geological Survey (2018a) using the site numbers. USGS, U.S. Geological Survey; NAVD 88, North American Vertical Datum of 1988]

\begin{tabular}{|c|c|c|c|c|c|c|c|c|c|}
\hline USGS site number & Station name ${ }^{1}$ & $\begin{array}{l}\text { Northing, in } \\
\text { Nebraska } \\
\text { State Plane } \\
\text { meters }\end{array}$ & $\begin{array}{l}\text { Easting, in } \\
\text { Nebraska } \\
\text { State Plane } \\
\text { meters }\end{array}$ & $\begin{array}{l}\text { Land-surface } \\
\text { elevation (meters } \\
\text { above NAVD 88) }\end{array}$ & $\begin{array}{l}\text { Water level } \\
\text { (meters below } \\
\text { land surface) }\end{array}$ & $\begin{array}{l}\text { Water-level } \\
\text { measurement } \\
\text { date }\end{array}$ & $\begin{array}{l}\text { Water-level el- } \\
\text { evation (meters } \\
\text { above NAVD 88) }\end{array}$ & $\begin{array}{l}\text { Well depth } \\
\text { (meters) }\end{array}$ & $\begin{array}{c}\text { Used or } \\
\text { not used in } \\
\text { spring } 2017 \\
\text { water-level } \\
\text { surface map }\end{array}$ \\
\hline 421236097273600 & 26N 1W20CCAA1 & $266,956.1$ & $709,606.5$ & 490.94 & 10.99 & $3 / 20 / 2017$ & 479.95 & 50.60 & Used \\
\hline 421241097313500 & $26 \mathrm{~N} 2 \mathrm{~W} 22 \mathrm{DACB} 1$ & $266,951.5$ & $704,123.3$ & 482.98 & 1.52 & $3 / 20 / 2017$ & 481.46 & 28.35 & Used \\
\hline 421256098021001 & $26 \mathrm{~N} 6 \mathrm{~W} 20 \mathrm{ACB} 1$ & $266,335.2$ & $662,045.5$ & 572.56 & 19.52 & $3 / 20 / 2017$ & 553.03 & 96.62 & Used \\
\hline 421257098141401 & $26 \mathrm{~N} 8 \mathrm{~W} 22 \mathrm{BAC} 1$ & $266,008.4$ & $645,446.4$ & 558.19 & 5.67 & $3 / 20 / 2017$ & 552.53 & 89.31 & Used \\
\hline 421304097335400 & $26 \mathrm{~N} 2 \mathrm{~W} 20 \mathrm{AACC} 1$ & $267,570.3$ & $700,917.0$ & 497.58 & 4.58 & $3 / 20 / 2017$ & 492.99 & 46.25 & Used \\
\hline 421418097483000 & $26 \mathrm{~N} 4 \mathrm{~W} 8 \mathrm{CDBB} 1$ & $269,315.4$ & $680,779.4$ & 532.66 & 8.91 & $4 / 3 / 2017$ & 523.75 & 96.12 & Used \\
\hline 421421097433700 & 26N 4W12CADD1 & $269,581.1$ & $687,491.1$ & 537.86 & 17.45 & $4 / 3 / 2017$ & 520.42 & 99.36 & Used \\
\hline 421500097404800 & $26 \mathrm{~N} 3 \mathrm{~W} 4 \mathrm{CCCC} 1$ & $270,886.5$ & $691,331.4$ & 516.48 & 14.93 & $3 / 21 / 2017$ & 501.55 & 67.56 & Used \\
\hline 421512098145201 & $27 \mathrm{~N} 8 \mathrm{~W} 33 \mathrm{DBA} 1$ & $270,154.1$ & $644,490.8$ & 588.48 & 30.29 & $3 / 17 / 2017$ & 558.18 & 79.86 & Used \\
\hline 421534097572301 & $26 \mathrm{~N} 6 \mathrm{~W} 1 \mathrm{ABD} 1$ & $271,360.0$ & $668,509.7$ & 573.86 & 23.53 & $3 / 16 / 2017$ & 550.33 & 43.28 & Used \\
\hline 421539097453500 & 26N 4W 3AACC1 & $271,915.8$ & $684,724.8$ & 527.22 & 6.46 & $4 / 3 / 2017$ & 520.77 & 88.39 & Used \\
\hline 421541097343300 & $26 \mathrm{~N} 2 \mathrm{~W} 5 \mathrm{BBDD} 1$ & $272,386.2$ & $699,887.2$ & 488.77 & 2.41 & $4 / 3 / 2017$ & 486.36 & 33.53 & Used \\
\hline 421602097520501 & $27 \mathrm{~N} 5 \mathrm{~W} 35 \mathrm{CAC} 1$ & $272,399.3$ & $675,773.4$ & 555.15 & 17.82 & $3 / 16 / 2017$ & 537.33 & 53.34 & Used \\
\hline 421621098050401 & $27 \mathrm{~N} 7 \mathrm{~W} 36 \mathrm{BC} 1$ & $272,567.7$ & $657,916.3$ & 588.80 & 25.53 & $3 / 20 / 2017$ & 563.27 & 119.79 & Used \\
\hline 421701098022201 & 27N 6W29CA 1 & $273,884.5$ & $661,599.0$ & 591.19 & 31.75 & $4 / 13 / 2017$ & 559.44 & 59.44 & Used \\
\hline 421708097364100 & 27N 3W25DBBB1 & $274,987.4$ & $696,881.1$ & 506.77 & 13.72 & $3 / 21 / 2017$ & 493.05 & 45.72 & Used \\
\hline 421721097593601 & $27 \mathrm{~N} 6 \mathrm{~W} 27 \mathrm{AO} 1$ & $274,588.4$ & $665,386.2$ & 585.43 & 33.79 & $3 / 16 / 2017$ & 551.64 & 67.36 & Used \\
\hline 421745097383801 & $27 \mathrm{~N} 3 \mathrm{~W} 22 \mathrm{DDBC} 1$ & $276,054.9$ & $694,171.0$ & 518.07 & 19.29 & $3 / 21 / 2017$ & 498.78 & 51.82 & Used \\
\hline 421751097295100 & 27N 2W24CACC1 & $276,578.6$ & $706,230.4$ & 534.04 & 36.20 & $3 / 20 / 2017$ & 497.84 & 82.30 & Used \\
\hline 421909097291600 & 27N 2W13AACC1 & $279,006.9$ & $706,961.7$ & 521.36 & 20.32 & $3 / 20 / 2017$ & 501.04 & 67.37 & Used \\
\hline 421927098102501 & 27N 7W 7DBC 1 & $278,144.9$ & $650,442.3$ & 582.69 & 24.41 & $3 / 17 / 2017$ & 558.29 & 48.46 & Used \\
\hline 422023097424300 & $27 \mathrm{~N} 3 \mathrm{~W} 6 \mathrm{CDBB} 1$ & $280,776.6$ & $688,432.9$ & 524.69 & 19.53 & $4 / 3 / 2017$ & 505.16 & 50.29 & Used \\
\hline 422024097343300 & $27 \mathrm{~N} 2 \mathrm{~W} 5 \mathrm{CCAA} 1$ & $281,112.7$ & $699,642.4$ & 525.67 & 26.19 & $4 / 3 / 2017$ & 499.48 & 57.91 & Used \\
\hline 422026097490500 & 27N 4W 6DACC1 & $280,643.3$ & $679,690.8$ & 531.17 & 9.58 & $4 / 3 / 2017$ & 521.58 & 22.56 & Used \\
\hline 422028097295100 & $27 \mathrm{~N} 2 \mathrm{~W} 1 \mathrm{CACC} 1$ & $281,419.7$ & $706,090.2$ & 544.27 & 46.95 & $3 / 20 / 2017$ & 497.32 & 73.15 & Used \\
\hline 422038098150701 & 27N 8W 4ACC 1 & $280,201.2$ & $643,943.7$ & 589.36 & 33.16 & $3 / 10 / 2017$ & 556.21 & 69.80 & Used \\
\hline 422039098005901 & 27N 6W 4ACD 1 & $280,650.8$ & $663,345.5$ & 554.85 & 6.42 & $3 / 16 / 2017$ & 548.43 & 42.67 & Used \\
\hline 422049097410500 & $27 \mathrm{~N} 3 \mathrm{~W} 5 \mathrm{ADBB} 1$ & $281,638.0$ & $690,653.5$ & 508.68 & 3.68 & $4 / 3 / 2017$ & 505.00 & 38.10 & Used \\
\hline 422049097414500 & $27 \mathrm{~N} 3 \mathrm{~W} 5 \mathrm{BCAA} 1$ & $281,613.5$ & $689,738.5$ & 516.21 & 7.71 & $4 / 3 / 2017$ & 508.49 & 32.00 & Used \\
\hline
\end{tabular}


[Data are available in U.S. Geological Survey (2018a) using the site numbers. USGS, U.S. Geological Survey; NAVD 88, North American Vertical Datum of 1988]

\begin{tabular}{|c|c|c|c|c|c|c|c|c|c|}
\hline USGS site number & Station name ${ }^{1}$ & $\begin{array}{l}\text { Northing, in } \\
\text { Nebraska } \\
\text { State Plane } \\
\text { meters }\end{array}$ & $\begin{array}{l}\text { Easting, in } \\
\text { Nebraska } \\
\text { State Plane } \\
\text { meters }\end{array}$ & $\begin{array}{l}\text { Land-surface } \\
\text { elevation (meters } \\
\text { above NAVD 88) }\end{array}$ & $\begin{array}{l}\text { Water level } \\
\text { (meters below } \\
\text { land surface) }\end{array}$ & $\begin{array}{l}\text { Water-level } \\
\text { measurement } \\
\text { date }\end{array}$ & $\begin{array}{l}\text { Water-level el- } \\
\text { evation (meters } \\
\text { above NAVD 88) }\end{array}$ & $\begin{array}{l}\text { Well depth } \\
\text { (meters) }\end{array}$ & $\begin{array}{c}\text { Used or } \\
\text { not used in } \\
\text { spring } 2017 \\
\text { water-level } \\
\text { surface map }\end{array}$ \\
\hline 422116097522401 & $28 \mathrm{~N} 5 \mathrm{~W} 34 \mathrm{DDA} 1$ & $282,071.8$ & $675,099.9$ & 543.03 & 11.70 & $3 / 15 / 2017$ & 531.33 & 28.96 & Used \\
\hline 422117097343300 & $28 \mathrm{~N} 2 \mathrm{~W} 32 \mathrm{CCAA} 1$ & $282,747.0$ & $699,596.5$ & 515.68 & 14.04 & $3 / 20 / 2017$ & 501.64 & 35.66 & Used \\
\hline 422118097461000 & 28N 4W34CACC1 & $282,349.0$ & $683,653.2$ & 520.78 & 9.82 & $4 / 3 / 2017$ & 510.97 & 49.38 & Used \\
\hline 422150097402401 & $\begin{array}{l}28 \mathrm{~N} 3 \mathrm{~W} 33 \mathrm{BA} 1 \\
\text { OSMOND }\end{array}$ & $283,696.3$ & $691,704.4$ & 509.81 & 8.42 & 2/7/2017 & 501.39 & 36.88 & Used \\
\hline 422205098145101 & $28 \mathrm{~N}$ 8W28D 1 & $282,891.8$ & $644,255.4$ & 564.45 & 14.33 & $3 / 10 / 2017$ & 550.12 & 89.16 & Used \\
\hline 422224097450500 & 28N 4W26BCDD1 & $284,422.8$ & $685,087.0$ & 513.52 & 5.32 & $3 / 20 / 2017$ & 508.20 & 39.62 & Used \\
\hline 422325097472400 & 28N 4W21BCAA1 & $286,222.0$ & $681,860.4$ & 544.35 & 34.05 & $3 / 20 / 2017$ & 510.30 & 67.97 & Used \\
\hline 422329097370300 & 28N 3W24BBDD1 & $286,722.1$ & $696,053.4$ & 539.00 & 40.07 & $3 / 20 / 2017$ & 498.92 & 6.66 & Used \\
\hline 422433098042401 & 28N 7W12DCD 1 & $287,761.4$ & $658,494.3$ & 529.95 & 8.44 & $3 / 16 / 2017$ & 521.51 & 67.67 & Used \\
\hline 422436098144501 & $28 \mathrm{~N} 8 \mathrm{~W} 9 \mathrm{DD} 1$ & $287,551.7$ & $644,298.1$ & 520.98 & 0.32 & $4 / 12 / 2017$ & 520.66 & 4.36 & Used \\
\hline & $\begin{array}{r}\text { 28N 3W 8DDAD1 } \\
\text { CNBRLUSCR1 }\end{array}$ & & & & & & & & \\
\hline 422441097404601 & $\mathrm{P}-04$ & $288,798.0$ & $690,919.7$ & 523.16 & 14.40 & $6 / 6 / 2017$ & 508.75 & 18.29 & Used \\
\hline 422444097362300 & 28N 3W12DDBB1 & $289,060.1$ & $696,903.7$ & 535.28 & 33.97 & $3 / 20 / 2017$ & 501.31 & 77.42 & Used \\
\hline 422533097512901 & $28 \mathrm{~N} 5 \mathrm{~W} 2 \mathrm{ADB} 1$ & $290,920.0$ & $676,025.2$ & 506.17 & 5.84 & $3 / 16 / 2017$ & 500.33 & 29.87 & Used \\
\hline 422600097590601 & $28 \mathrm{~N} 6 \mathrm{~W} 2 \mathrm{BAC} 1$ & $290,610.2$ & $665,700.1$ & 537.21 & 17.24 & $3 / 16 / 2017$ & 519.97 & 77.72 & Used \\
\hline 422605097474200 & 28N 4W 5AADD1 & $291,145.7$ & $681,323.0$ & 534.17 & 33.20 & $3 / 20 / 2017$ & 500.97 & 64.62 & Used \\
\hline 422616097531101 & 29N 5W34DCCC1 & $291,297.2$ & $673,798.5$ & 494.59 & 1.87 & $4 / 5 / 2017$ & 492.72 & 17.98 & Used \\
\hline 422618097451100 & 29N 4W35CDCC1 & $291,635.4$ & $684,762.2$ & 526.90 & 20.93 & $3 / 20 / 2017$ & 505.97 & 56.39 & Used \\
\hline 422619097331600 & $29 \mathrm{~N} 2 \mathrm{~W} 33 \mathrm{CDDC} 1$ & $292,109.2$ & $701,094.1$ & 524.74 & 26.57 & $3 / 20 / 2017$ & 498.18 & 45.72 & Used \\
\hline 422628097481201 & 29N 4W32DCAA1 & $291,837.6$ & $680,619.6$ & 543.32 & 38.70 & $4 / 5 / 2017$ & 504.62 & 74.37 & Used \\
\hline 422735098181501 & 29N 8W30BCCC1 & $292,976.8$ & $639,389.6$ & 576.04 & 25.09 & $5 / 12 / 2017$ & 550.95 & 97.54 & Used \\
\hline 422849098110401 & 29N 7W19BB 1 & $295,459.1$ & $649,185.6$ & 524.49 & 12.86 & $5 / 12 / 2017$ & 511.63 & 62.18 & Used \\
\hline 422853097512601 & 29N 5W13CCCC1 & $296,198.2$ & $676,077.2$ & 509.03 & 12.98 & $4 / 5 / 2017$ & 496.06 & 25.30 & Used \\
\hline 422907098104801 & 29N 7W18CDBB1 & $296,021.9$ & $649,539.2$ & 525.64 & 6.95 & $5 / 12 / 2017$ & 518.69 & 57.30 & Used \\
\hline 422911097283101 & 29N 1W18CADD1 & $297,600.1$ & $707,449.1$ & 562.23 & 87.61 & $4 / 17 / 2017$ & 474.62 & 97.54 & Used \\
\hline 422955097433201 & $29 \mathrm{~N} 4 \mathrm{~W} 12 \mathrm{DCA} 1$ & $298,386.6$ & $686,847.6$ & 534.83 & 39.82 & $4 / 5 / 2017$ & 495.01 & 64.80 & Used \\
\hline 423027097340000 & 29N 2W 8AACC1 & $299,728.6$ & $699,873.6$ & 553.55 & 77.06 & $3 / 20 / 2017$ & 476.49 & 93.57 & Used \\
\hline 423041097402600 & $29 \mathrm{~N} 3 \mathrm{~W} 4 \mathrm{CDDD} 1$ & $299,918.0$ & $691,054.3$ & 534.31 & 48.34 & $3 / 20 / 2017$ & 485.98 & 75.29 & Used \\
\hline
\end{tabular}


Table 3. Measured water levels in wells completed in the High Plains aquifer within the Bazile Groundwater Management Area, spring 2017.-Continued

[Data are available in U.S. Geological Survey (2018a) using the site numbers. USGS, U.S. Geological Survey; NAVD 88, North American Vertical Datum of 1988]

\begin{tabular}{|c|c|c|c|c|c|c|c|c|c|}
\hline USGS site number & Station name ${ }^{1}$ & $\begin{array}{c}\text { Northing, in } \\
\text { Nebraska } \\
\text { State Plane } \\
\text { meters }\end{array}$ & $\begin{array}{l}\text { Easting, in } \\
\text { Nebraska } \\
\text { State Plane } \\
\text { meters }\end{array}$ & $\begin{array}{l}\text { Land-surface } \\
\text { elevation (meters } \\
\text { above NAVD 88) }\end{array}$ & $\begin{array}{l}\text { Water level } \\
\text { (meters below } \\
\text { land surface) }\end{array}$ & $\begin{array}{c}\text { Water-level } \\
\text { measurement } \\
\text { date }\end{array}$ & $\begin{array}{l}\text { Water-level el- } \\
\text { evation (meters } \\
\text { above NAVD 88) }\end{array}$ & $\begin{array}{c}\text { Well depth } \\
\text { (meters) }\end{array}$ & $\begin{array}{c}\text { Used or } \\
\text { not used in } \\
\text { spring } 2017 \\
\text { water-level } \\
\text { surface map }\end{array}$ \\
\hline 423208097355901 & $30 \mathrm{~N} 2 \mathrm{~W} 31 \mathrm{BCAB} 1$ & $302,767.4$ & $697,071.8$ & 542.67 & 53.16 & $4 / 5 / 2017$ & 489.51 & 72.85 & Used \\
\hline 423303097280901 & $30 \mathrm{~N} 1 \mathrm{~W} 30 \mathrm{ADBB} 1$ & $304,768.9$ & $707,741.7$ & 510.43 & 31.96 & $4 / 17 / 2017$ & 478.47 & 52.43 & Used \\
\hline 421738097342900 & $27 \mathrm{~N} 2 \mathrm{~W} 20 \mathrm{CDCC} 1$ & $275,996.5$ & $699,877.5$ & 505.54 & 4.09 & $4 / 3 / 2017$ & 501.44 & 35.66 & Not used \\
\hline 422156097314301 & $\begin{array}{l}\text { 28N 2W34ABAA1 } \\
\text { CNBRLUSCR1 } \\
\text { P-03 } \\
\text { 29N 2W28BBCB1 } \\
\text { CNBRLUSCR1 } \\
\text { K-05 }\end{array}$ & $284,060.0$ & $703,475.9$ & 537.68 & 8.70 & $6 / 6 / 2017$ & 528.98 & 11.89 & Not used \\
\hline
\end{tabular}

${ }^{1}$ Legal description: T., township; N, north; R., range; W, west; S., section. $\mathrm{ABCD}$, codes for the quarter section, as $\mathrm{A}, \mathrm{B}, \mathrm{C}$, and D, respectively from largest to smallest quarter, where A is northeast, B is northwest, $\mathrm{C}$ is southwest, and $\mathrm{D}$ is southeast quarter of the next larger unit, and (optional) field name for the well. 
and influence of pumping on groundwater levels. The continuous water-level data are interpreted within the context of an improved hydrogeologic framework.

\section{Interpretation of Hydrogeologic Data}

This section of the report describes the joint interpretation of water-quality and water-level data within an improved hydrostratigraphic and geologic framework. This section is broken out into two different sections. The "Interpretation of Water-Quality and Age Tracer Data" subsection describes the results of age tracer studies, the vulnerability of groundwater resources to surface contamination, and estimated rates of groundwater recharge across the BGMA. The "Interpretation of Continuous Water-Level Data" subsection describes the interpretation of continuous groundwater-level data collected within the BGMA to assess the degree of confinement and hydraulic connectivity between upper and lower parts of the aquifer.

Within this section, water-quality and water-level data collected from wells near AEM profiles and interpretations are described. Geoscene3D is a data exploration and communication tool that allows the user to simultaneously examine $\mathrm{AEM}$, test-hole, and water-quality data in a $3 \mathrm{D}$ environment; however, data are presented here in two-dimensional space. Because test holes and monitoring wells are often located some distance away from the AEM profile, it is difficult or nearly impossible for the user to determine the depth of the monitoring wells while viewing the monitoring wells and AEM profiles in 3D space. An example of this is shown in figure $5 \mathrm{~A}$, where a pair of monitoring wells are plotted near an AEM profile, and the same profile presented as a twodimensional profile is shown in figure $5 B$. The pair of monitoring wells shown in figure $5 A$ appear to be much shallower than depicted in figure $5 B$, which is a result of forced perspective because the wells are more distant than the AEM profile.

\section{Interpretation of Water-Quality and Age Tracer Data}

Groundwater age tracer sampling results from several studies (Burbach and Spalding, 2000; Stanton and others, 2007b; Snow and Miller, 2018; U.S. Geological Survey, 2018a) that included all or parts of the BGMA were assembled and jointly interpreted with AEM data within a 3D environment. The combined age tracer dataset was examined to determine groundwater residence time, understand historical nitrate loading to groundwater, and estimate groundwater recharge rates. Nitrate concentration results from samples collected at the time of the age tracer sampling, along with more recent nitrate concentration data from the agrichemical clearinghouse (University of Nebraska-Lincoln, 2019), were examined to assess the vulnerability of groundwater resources to surface contamination. Recharge rates were estimated to assess the effect of irrigation and other land uses on the rates of water movement from the land surface to the aquifer.

Age tracer and nitrate data indicate that recent recharge or "modern" groundwater has nitrate concentrations that exceed a background concentration of $2 \mathrm{mg} / \mathrm{L}$ (Mueller and Helsel, 1996). For the purposes of this report, modern groundwater is considered to have recharged less than 50 years from the time of sampling. In the BGMA area, nitrate concentrations for modern groundwater collected at the time of age tracer sampling ranged from 1.96 to $35.3 \mathrm{mg} / \mathrm{L}$ with more than 70 percent of the samples exceeding the $10 \mathrm{mg} / \mathrm{L}$ maximum contaminant level (table 5; available at https://doi.org/10.3133/ sir20205113). Burbach and Spalding (2000) focused much of their work near Creighton, Nebr., (fig. 1) in an area that Cannia and others (2017a) characterized as having a relatively thin unsaturated zone consisting of primarily coarse sediments overlying a thin aquifer composed of coarse sediment. Within the Creighton Water System block flight area (fig. $3 A$ ), elevated concentrations of nitrate are reported for shallow and deep monitoring wells (table 5; ML-6D, ML-6M, and ML-6S). Fine-grained materials are discontinuous and largely limited to the southern part of the Creighton Water System block flight area (fig. 3A; Cannia and others, 2017a). Profile L128701 and wells ML-6D, ML-6M, and ML-6S, which are approximately $4 \mathrm{~km}$ northeast of Creighton (fig. 6), are in an area where the unsaturated zone is relatively thin, and the aquifer is less than $20 \mathrm{~m}$ thick. At the location of these wells, groundwater is considered modern and elevated levels of nitrate are present throughout the entire thickness of the aquifer.

In contrast, some samples collected from wells in BGMA areas with thicker unsaturated zones and thicker aquifers indicate that groundwater was recharged more than 50 years ago, which for the purposes of this report is considered "premodern" groundwater. Nitrate concentrations of pre-modern groundwater collected at the time of sampling were generally less than the background concentration of $2 \mathrm{mg} / \mathrm{L}$ (table 5; Mueller and Helsel, 1996). This low nitrate concentration indicates that groundwater sampled in deeper wells followed a longer flow path from a distant recharge area and that the deeper, pre-modern groundwater was not subjected to the same sources of nitrate as the shallow groundwater, or that the aquifer is locally confined or semiconfined. Except for the work done by Snow and Miller (2018), many of the age tracer studies were completed more than a decade ago. Many of the wells sampled in age tracer studies continue to be sampled repeatedly as part of routine groundwater monitoring for nitrate. Examining the most recent nitrate concentrations reported in the agrichemical clearinghouse (University of Nebraska-Lincoln, 2019) from the deeper wells indicates that the water quality has not changed in the lower of the High Plains aquifer because nitrate concentrations in these wells have remained less than $1 \mathrm{mg} / \mathrm{L}$. One example is well 2D, where nitrate concentration has remained steady from 2007 to 2016, whereas nitrate concentration in well $2 \mathrm{M}$ was $15.7 \mathrm{mg} / \mathrm{L}$ at the time of age tracer sampling and was $21.2 \mathrm{mg} / \mathrm{L}$ in the 

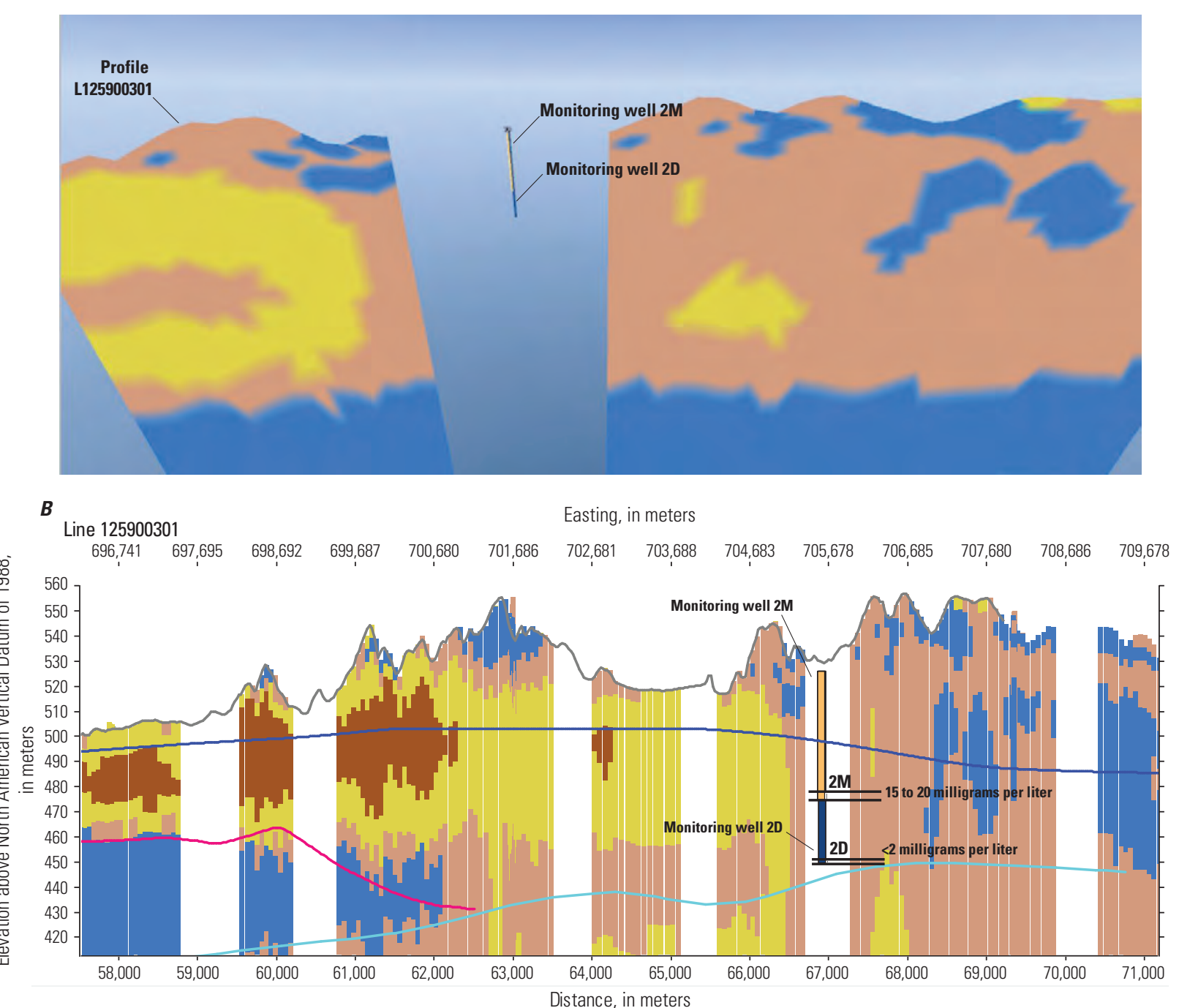

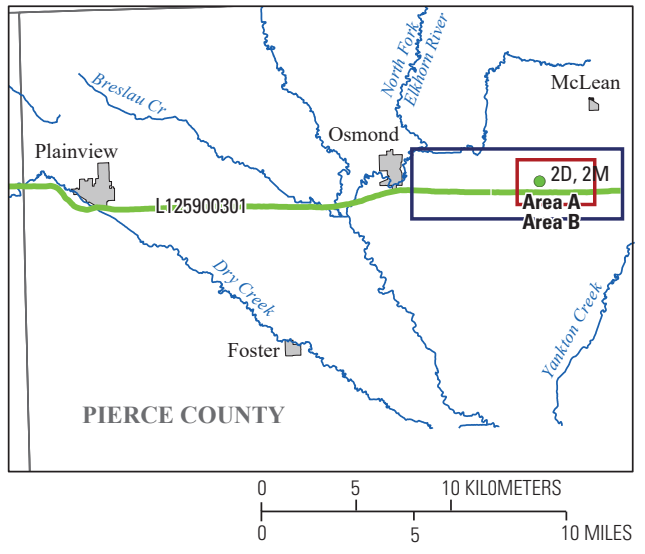

\section{EXPLANATION}

Interpreted geologic material (Cannia and others, 2017b)

Nonaquifer

Marginal aquifer

Aquifer

Coarse aquife

No data

Nitrate concentration category in milligrams per liter ( $A$ only, University of Nebraska-Lincoln, 2019 $<2$

15 to $<20$

\section{Interpolated surface}

- Land surface

Water level, spring 2017

_ Top of Pierre Shale

- Top of Niobrara Formation

- L-125900301- Airborne electromagnetic survey line and identifier

2D 。 Well location and identifier

Figure 5. Example airborne electromagnetic (AEM) and water-quality data displayed within the Geoscene3D program. A, A portion of AEM profile L125900301 and monitoring wells 2M and 2D shown in three-dimensional space. View is looking 11 degrees east of north. B, A portion of AEM profile L125900301 and monitoring wells 2M and 2D shown in two-dimensional space. Monitoring wells 2D and 2M are approximately 585 meters north of AEM profile L125900301. The location of AEM profile L125900301 is shown in figure 3A. 
latest sampling results (table 5). The interpreted hydrostratigraphic profiles from AEM data and test-hole data in the area including well 2D were visualized in 3D space (fig. 7). An examination of test-hole log 14-A-98 (Conservation and Survey Division, University of Nebraska-Lincoln, 2019a) near monitoring wells $2 \mathrm{D}$ and $2 \mathrm{M}$ determined there are no fine-grained layers that would restrict the vertical movement of water between wells $2 \mathrm{M}$ and 2D. The lack of fine-grained layers is consistent with AEM profile L125900301, which indicates that nonaquifer material is not present, though the data near wells $2 \mathrm{M}$ and 2D were removed because the data were likely affected by cultural noise, such as powerlines or buried pipelines. As a result, continued sampling of well 2D is needed to monitor and track any movement of nitrate through the deeper parts of the aquifer.

In the western part of the BGMA, monitoring wells $15 \mathrm{~S}$, $15 \mathrm{M}$, and $15 \mathrm{D}$ are screened in different parts of the High Plains aquifer and are near test hole 8-UE-01 and AEM profile L125900401 (fig. 8). Nitrate and age tracer data indicate that well $15 \mathrm{~S}$ can be characterized as modern water with elevated levels of nitrate (table 5), whereas, monitoring wells $15 \mathrm{M}$ and $15 \mathrm{D}$, which are screened in deeper parts of the aquifer, are considered pre-modern with low concentrations of nitrate (table 5). An examination of the hydrostratigraphic interpretation of AEM profile L125900401 and test hole 8-UE-01 indicate that at the location of the wells, there are three intervals described in the test hole as silt/loess approximately $6 \mathrm{~m}$ in total thickness (Conservation and Survey Division, University of Nebraska-Lincoln, 2019a), but the AEM profile L125900401 indicates that there is no nonaquifer or marginal aquifer material overlying the screens of wells $15 \mathrm{M}$ and $15 \mathrm{D}$. The lack of nonaquifer or marginal aquifer material indicates that the AEM method is not detecting fine-grained layers at a depth because of decreased resolution. These fine-grained layers could have substantial effect on the water quality of the lower part of the High Plains aquifer. With the information available, it is not known if the fine-grained layers above wells $15 \mathrm{M}$ and $15 \mathrm{D}$, and reported in the test hole, will prevent groundwater with higher concentrations of nitrate from reaching the lower part of the High Plains aquifer.

These comparisons highlight the importance of examining not only the hydrostratigraphic interpretation of AEM profiles, but also any test-hole logs or drillers' logs when assessing the vulnerability of the deeper parts of the High Plains aquifer to surface contamination. Visualization of the area within Geoscene3D aids in this process. In general, AEM surveying is best suited for mapping regional geologic units (Carney and others, 2015a, b), but researchers have reported the ability to map and detect local confining layers (Korus, 2018). Within the BGMA, we have presented an example (fig. 8) where thin or interbedded fine-grained layers, which may reduce the hydrologic connectivity and restrict the downward movement of contaminants, were not mappable with AEM because of the decreased vertical resolution with depth. We have also presented an example (fig. 7) where saturated thickness was an important factor to consider when evaluating water-quality data. Nitrate results from monitoring wells sampling deeper groundwater may be dissimilar to results in shallower wells at this location because the water in the deeper well likely was recharged at distant sources prior to the widespread use of chemical fertilizers.

\section{Age Tracer Based Recharge Estimates}

Estimates of groundwater recharge were used to evaluate the rates of contaminant movement and assess the vulnerability of groundwater resources to surface contamination. Groundwater recharge rates were calculated by estimating the vertical groundwater velocity at the water table using age tracer data and well depth information. Recharge rates were not calculated for wells considered to be pre-modern. This approach described in Delin and others $(2000,2007)$ and Steele and others (2014) assumes unconfined conditions and an exponential age distribution of groundwater with depth and allows for the calculation of the vertical groundwater velocity $(V)$ using equation 1 :

$$
V=\frac{Z}{\text { age(i) }} * \ln \frac{Z}{[Z-z(i)]}
$$

where

$$
\begin{gathered}
V \quad \text { is the vertical groundwater velocity, in } \\
\text { centimeters per year; } \\
\text { is the thickness of the saturated zone, in } \\
\text { centimeters; } \\
\text { age }(i) \quad \begin{array}{l}
\text { is the age of the groundwater sample, in years } \\
\text { before sample date; and }
\end{array} \\
z(i) \quad \begin{array}{l}
\text { is the depth of the middle of the well screen, } \\
\text { in centimeters below the top of the } \\
\text { water table. }
\end{array}
\end{gathered}
$$

Groundwater recharge (in centimeters per year) is calculated by multiplying the mean saturated zone porosity $(\varphi)$ by $V$ using equation 2 :

$$
\text { Recharge }=\varphi V
$$

Groundwater recharge rates were also calculated using a linear groundwater age distribution using equation 3 :

$$
V=\frac{z(i)}{a g e}
$$

where

$$
\begin{aligned}
& V \quad \text { is the vertical groundwater velocity, in } \\
& \text { centimeters per year; } \\
& \text { is the depth of the middle of the well screen, } \\
& \text { in centimeters below the top of the water } \\
& \text { table; and } \\
& \text { is the age of the groundwater sample, in years } \\
& \text { before sample date. }
\end{aligned}
$$

As with the exponential age distribution approach, recharge is determined by multiplying $V$ by the mean saturated porosity using equation 2 . 

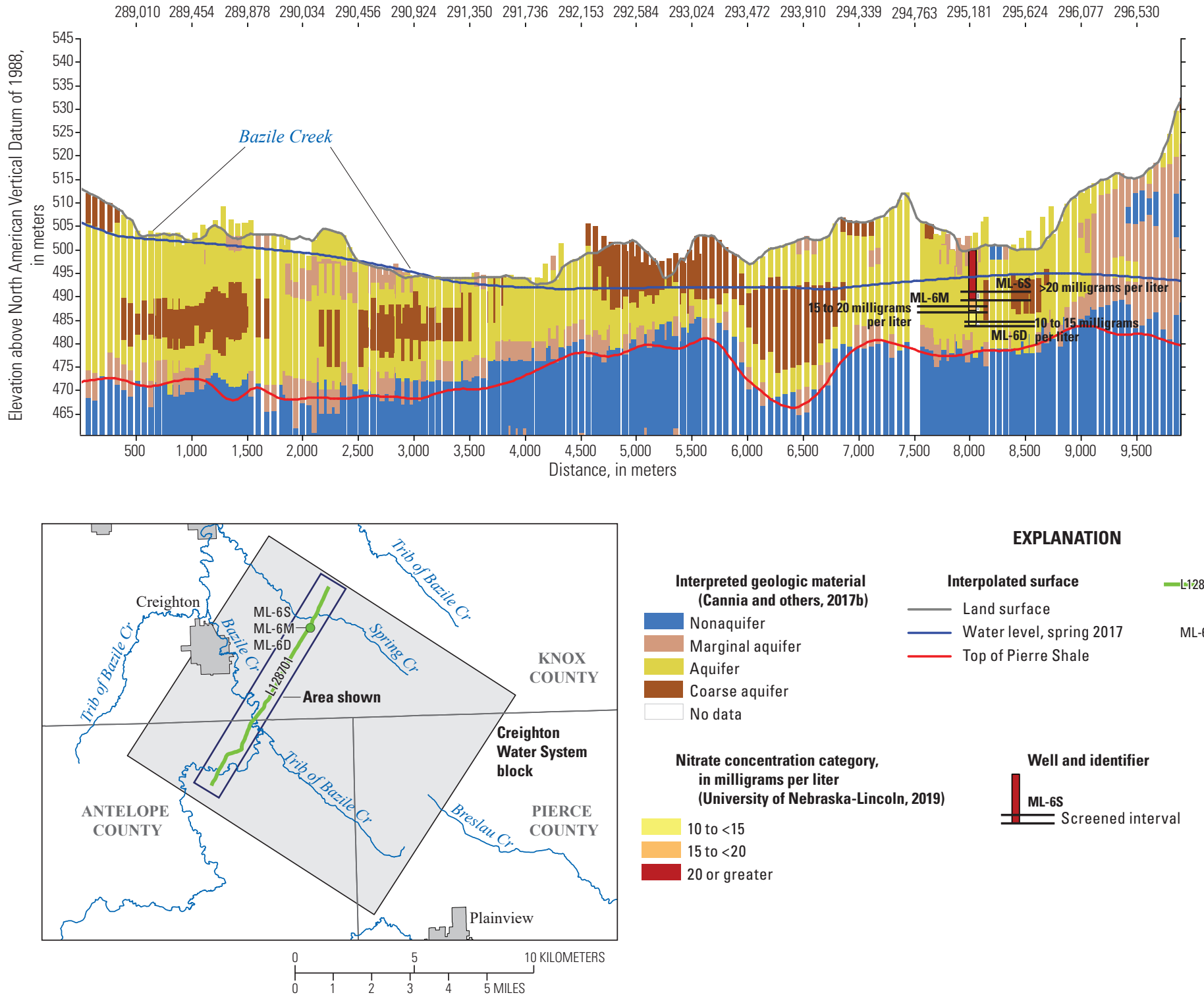

\section{EXPLANATION}

\begin{tabular}{|c|c|c|c|}
\hline $\begin{array}{l}\text { Interpreted geologic material } \\
\text { (Cannia and others, 2017b) }\end{array}$ & \multirow{5}{*}{$\begin{array}{l}\text { Interpolated surface } \\
\text { Land surface } \\
\text { Water level, spring } 2017 \\
\text { Top of Pierre Shale }\end{array}$} & \multirow{3}{*}{$\begin{array}{l}-\mathrm{L} 128701- \\
\mathrm{ML}-6 \mathrm{~S}_{\mathrm{O}}\end{array}$} & \multirow{3}{*}{$\begin{array}{l}\text { Airborne electromagnetic survey line } \\
\quad \text { and identifier } \\
\text { Well location and identifier }\end{array}$} \\
\hline $\begin{array}{l}\text { Nonaquifer } \\
\text { Marginal aquifer }\end{array}$ & & & \\
\hline Aquifer & & & \\
\hline Coarse aq & & & \\
\hline No data & & & \\
\hline
\end{tabular}

\section{Nitrate concentration category} in milligrams per liter (University of Nebraska-Lincoln, 2019) 10 to $<15$

15 to $<20$

20 or greater

Figure 6. Interpreted geologic mat profile L128701 is shown in figure $3 B$.

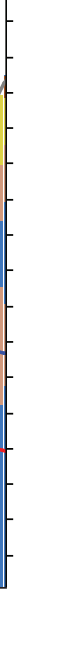




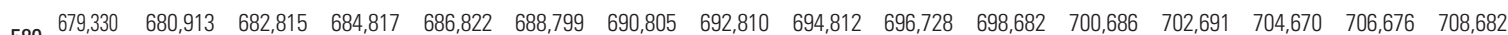

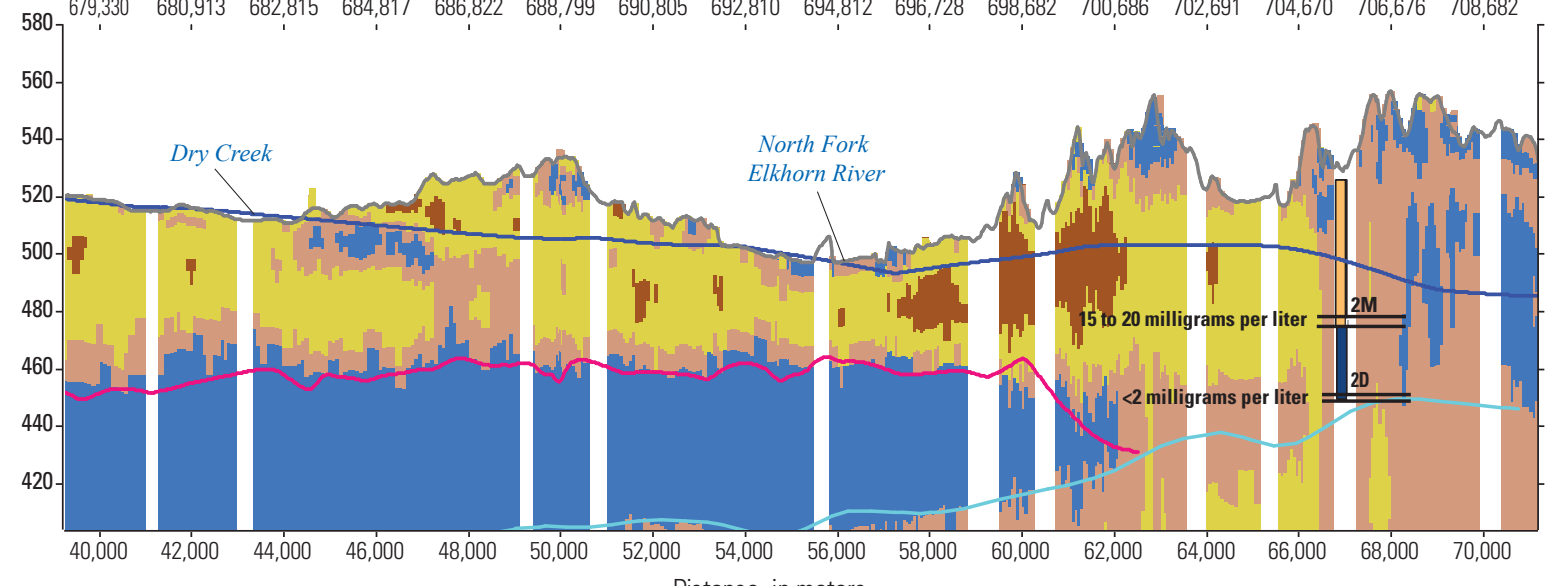

Distance, in meters

$$
\text { B WEST }
$$

Easting, in meters

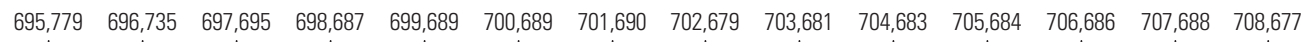

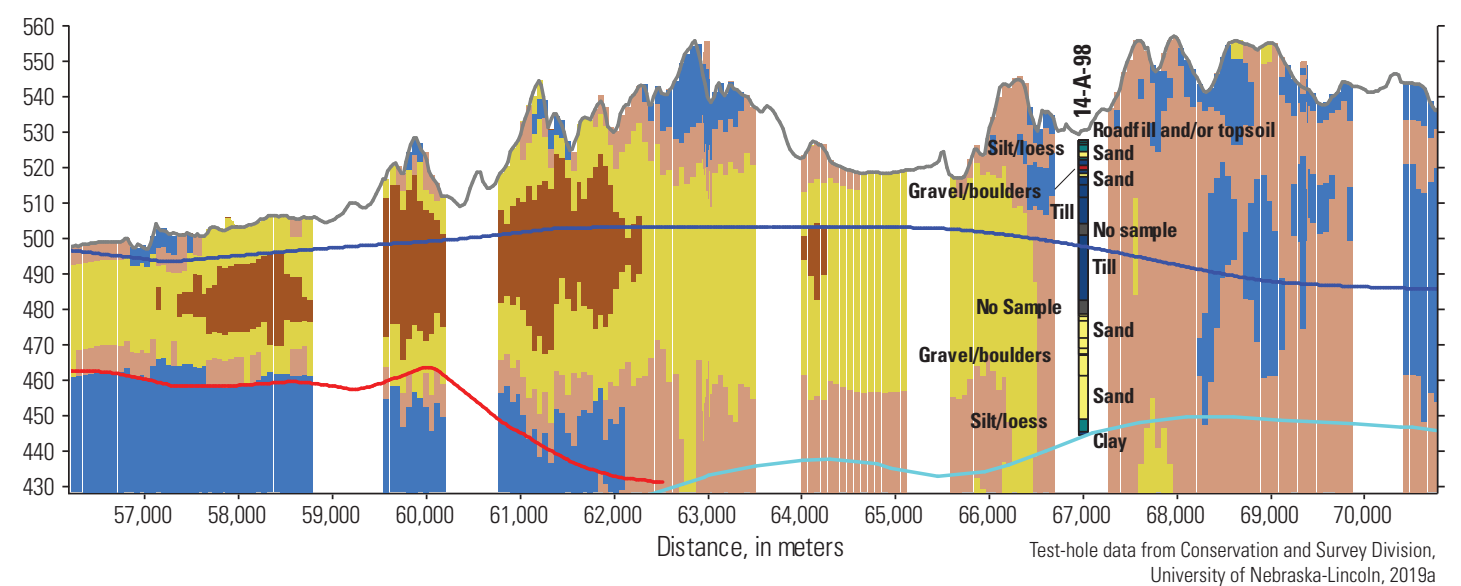

Figure 7. Interpreted geologic material of airborne electromagnetic (AEM) profile L125900301 and nitrate concentration of wells $2 \mathrm{D}$ and $2 \mathrm{M}$. $A$, interpreted geologic material of part of AEM profile L125900301. B, part of AEM profile L125900301 and generalized lithology of test hole 14-A-98. Monitoring wells 2D and 2M and test hole 14-A-98 are approximately 585 meters north of AEM profile L125900301. The location of AEM profile L125900301 is shown in figure $3 A$.

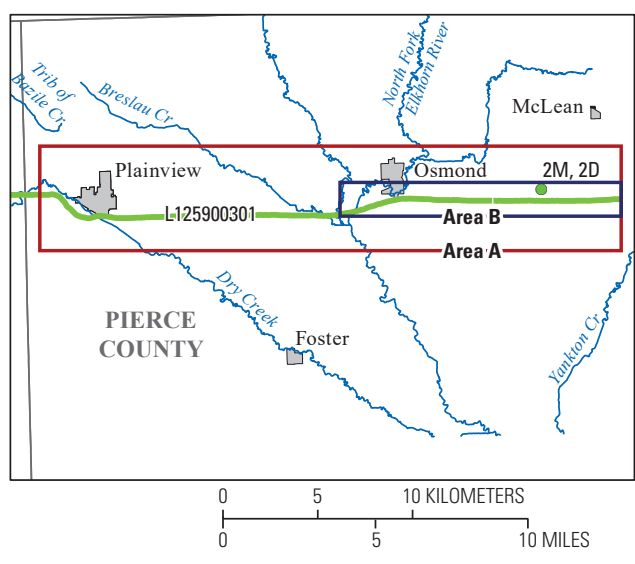

\section{EXPLANATION}

Interpreted geologic materia (Cannia and others, 2017b)

Nonaquif

Marginal aquife

Aquifer

Coarse aquifer

No data

\section{Nitrate concentration category,} in milligrams per liter $(A$ only,

University of Nebraska-Lincoln, 2019)

15 to $<20$

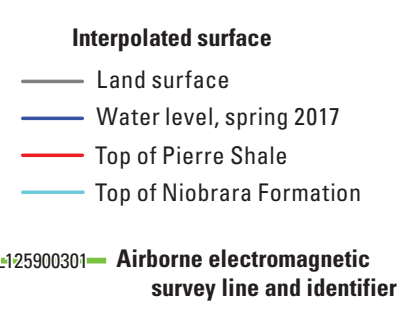

Test hole and identifie 
EAST

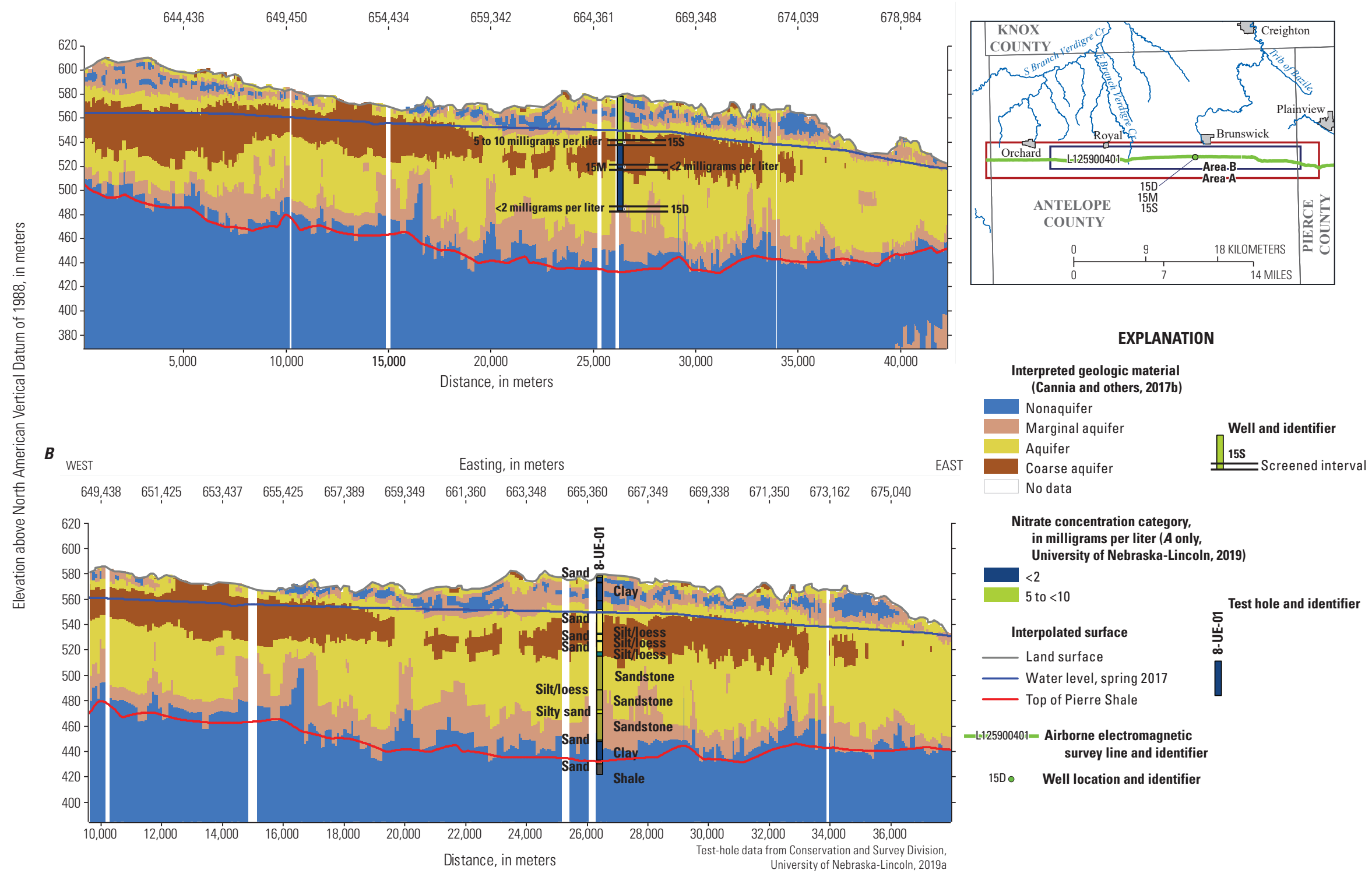

Figure 8. Interpreted geologic material of airborne electromagnetic (AEM) profile L125900401 and nitrate concentration of wells 15D, 15M, and 15S. $A$, interpreted geologic material of part of AEM profile L125900401. B, part of AEM profile L125900301 and generalized lithology of test hole 8-UE-01. Monitoring wells 15D, 15M, and 15S are approximately 89 meters south of AEM profile L125900401. The location of AEM profile L125900401 is shown in figure 3A. 
The thickness of the saturated zone was determined by using the measured water levels collected at the time of sampling and the revised base of aquifer (top of the Pierre Shale or Niobrara Formation) elevation from Cannia and others (2017a). Water levels from sampling in spring of 2000 (Burbach and Spalding, 2000) were not available; however, water-level data were available for the following summer for the deepest well within each well cluster (Myles Lammers, Lewis and Clark NRD, written commun., 2019). The depth below the top of the water table, $z(i)$, was calculated by subtracting the depth to water from the depth of the midpoint of the screen. In a few instances, the upper portion of the screen was above the water surface; in these cases, the midpoint depth between water table and the bottom of the well screen was used to determine $z(i)$.

Porosity values were estimated using values from generalized lithologic categories reported in Johnson (1967). For lithologic categories that are common aquifer materials within the BGMA (for example, medium or coarse sand), the porosity is about twice the specific yield (Johnson, 1967). Delin and others (2007) reported that specific yield numbers were about 30 to 50 percent less than porosity based on laboratory analyses. Specific yield values ranged from 0.125 to 0.175 for the High Plains aquifer within the BGMA (McGuire and others, 2012). Doubling the specific yield would result in porosities that range from 0.25 to 0.35 , which falls within the expected range (Johnson, 1967). Porosity values are given in table 5 for each well sampled.

Recharge calculated using equations 1, 2, and 3 for logarithmic and linear age distributions are presented in table 5. Linear age distributions assume piston flow, where an unconfined aquifer receives uniform areal recharge and monitoring well screens are short and within the shallow part of the aquifer (Steele and others, 2014). Conversely, exponential groundwater age distributions assume uniform recharge occurs over an unconfined aquifer (Jurgens and others, 2012) and age distribution lines converge exponentially from the water table to the base of the aquifer (Jurgens and others, 2012; Steele and others, 2014). Because of the proximity of the shallow monitoring wells to the water table, groundwater ages from the shallowest monitoring wells were used to determine recharge rates at the water table. Groundwater ages from the deeper wells likely represented recharge rates from distant locations or regional flow systems (Jurgens and others, 2012; Steele and others, 2014).

The calculated recharge rates (table 5) were comparable to regional estimates (Stanton and others, 2011; Szilagyi and Jozsa, 2013). The recharge rates (table 5) are presented with one of three generalized land use categories (Center for Advanced Land Management Information Technologies, 2007): pasture/rangeland, dryland, or irrigated. Excluding deeper wells from well nests, the recharge rates calculated do not vary appreciably for the various land uses, which differs from the results of previous studies (Steele and others, 2014). A Kruskal-Wallis test (Helsel and Hirsch, 2002) determined that the difference in distributions of recharge for each land use was not statistically significant (alpha equals 0.05 ). One well, G164447, was not used in this statistical comparison because the screen was $30 \mathrm{~m}$ long (table 5; fig. 4), which results in a relatively large $z(i)$ and anomalously high recharge rate. The outcome of the statistical test indicates that differences in land use are not the primary control on water movement through the unsaturated zone.

In many instances, monitoring wells are screened in the upper parts of the High Plains aquifer where water quality is most affected by surface activities; however, it is also common to screen wells in the first transmissive interval, which can often be some distance below the top of the water table. As such, there is the possibility of mixing of groundwater that has been recharged under different land uses. The density of highcapacity irrigation wells, which can exceed 3 wells per square mile (Upper Elkhorn Natural Resources District, 2016; Young and others, 2016), could be responsible for some aquifer mixing, possibly masking any influence of land use on groundwater recharge rates. Stanton and others (2007a) documented that high densities of irrigation wells caused groundwater mixing in the High Plains aquifer approximately $200 \mathrm{~km}$ to the south.

\section{Pesticide-Based Recharge Estimates}

Detections of pesticides or their degradants from wells within the BGMA were clustered in two locations (fig. 4). One location is in the southwest part of the BGMA where Cannia and others (2017a) interpreted coarse paleochannel deposits near land surface. In this location, sampled wells with detectable concentrations of pesticides span east to west across northern Antelope County in an area with a discontinuous cap of fine-grained material. An AEM profile that cuts through this paleochannel is shown in figure 9. The second location is east of Creighton, Nebr., within the Creighton Water System block flight area (figs. $3 A, 3 B$ ) where fine-grained material was discontinuous or absent from the near surface. In these locations, sampled wells with detectable concentrations of pesticides occur in areas with high nitrate concentrations and a discontinuous cap of fine-grained material. Of the 17 wells with pesticide detections, 11 wells were in irrigated areas, 3 were classified as dryland row crops areas, and 3 were within rangeland or pasture areas (Center for Advanced Land Management Information Technologies, 2007). Two wells (421940097313601 and 422231097520601 ) with nitrate concentrations less than or near the background concentration of $2 \mathrm{mg} / \mathrm{L}$ had pesticide detections from the same compound: 1,2-dichloropropane. The chemical, which is used as a soil and grain fumigant, was first registered for use in 1925 and banned in 1989. These wells are in pasture/rangeland areas, but they are also near the farmsteads where likely grain was stored, which could be the source of the pesticide.

Apparent groundwater ages from pesticide detections (table 6; available at https://doi.org/10.3133/sir20205113) were comparable to those estimated with age tracers (table 5) and appear to bracket groundwater ages well within the BGMA. It should be noted that the only monitoring wells 
available for direct comparison were ML-7M, ML-7D, and CNBRLUSCR1 P-03. The use of pesticides in groundwater as a tracer using this approach assumes piston flow, where recharged water is of uniform age with no mixing. Groundwater samples from irrigation wells that were screened near the base of the aquifer likely violate this assumption and most likely include mixed groundwater recharged from distance sources along deeper flow paths; however, the apparent age estimates from pesticide detections still constrain the age of the younger fraction within a sample.

\section{Interpretation of Continuous Water-Level Data}

Researchers have highlighted the value of continuous water-level interpretation in conjunction with AEM and test-hole data to detect and map confining layers in eastern Nebraska (Korus, 2018). Continuous water-level data (U.S. Geological Survey, 2018a) collected within the BGMA were examined together with the hydrostratigraphic interpretation of AEM profiles in Geoscene3D. Continuous water levels collected within the BGMA typically display water-level declines in response to groundwater irrigation during growing season months (typically June through August). Within the BGMA, the most informative continuous water-level data were collected simultaneously from nested monitoring wells screened in different parts of the High Plains aquifer. A comparison of the water levels in wells screened in shallow and deep parts of the aquifer can reveal the hydraulic connectivity of the shallow and deep parts of the aquifer, which is central to assessing the vulnerability of the deeper aquifer to surface contamination.

Monitoring wells 19S and 19M are completed in the High Plains aquifer and located within the glaciated part of the Lower Elkhorn NRD (figs. 1 and 4). The hydrograph shown in figure 10 indicates that groundwater levels are affected by seasonal pumping (between June and August) and most groundwater pumping is occurring at the same geologic horizon where monitoring well $19 \mathrm{M}$ is screened. Excluding the growing season months, the water-level elevation in well $19 \mathrm{M}$ is higher than 19S, producing a hydraulic gradient with a net upward movement of water. Groundwater pumping during the growing season causes the water level in well 19M to drop below that of well 19S, effectively reversing the hydraulic gradient. Although AEM profile L124900 is more than $500 \mathrm{~m}$ from these monitoring wells, useful comparisons and interpretations are described below. The hydrostratigraphic interpretation of AEM profile L124900 (fig. 11) shows a well-defined pocket of aquifer material within a heterogeneous mix of marginal and nonaquifer material. Both monitoring wells (19S and $19 \mathrm{M}$ ) are screened within this interval of aquifer material, which transitions to marginal and nonaquifer material near the base of the aquifer where $19 \mathrm{M}$ is screened (fig. 11). The nearest test hole to monitoring wells $19 \mathrm{M}$ and $19 \mathrm{~S}$ is 1-LE-03. The lithologic log of test hole 1-LE-03 indicates that the screen intervals in 19S and 19M are separated by $13 \mathrm{~m}$ of clay. The driller's log associated with monitoring well 19M noted this same clay layer (registration number G-124964B; Nebraska Department of Natural Resources, 2019). The clay layer, which would be interpreted as nonaquifer material, could not be resolved in AEM profile L124900 (fig. 11). Cannia and others (2017a) mention that agreement between the lithology of test hole 1-LE-03 and the AEM profile is marginal, particularly near the base of the aquifer. The clay layer appears to be a locally important confining layer and its role in affecting groundwater movement is apparent in testhole and groundwater-level data; however, in this location, the AEM technique appears to be unable to resolve this hydrologically important layer because of the lack of vertical resolution at depth.

Monitoring wells $3 \mathrm{~S}$ and $3 \mathrm{M}$ are located within the Lower Elkhorn NRD off the western margin of glacial till near a tributary to the North Fork of the Elkhorn River (figs. 1 and 4). Monitoring wells $3 \mathrm{~S}$ and $3 \mathrm{M}$ are both screened within Quaternary-age sand separated by an interval of silt (Conservation and Survey Division, University of NebraskaLincoln, 2019a). The continuously measured water-level elevations for each of these wells is shown in figure 12 and indicate that these parts of the aquifer are hydrologically well connected because the response to hydrologic stresses are nearly identical. Although both wells indicate seasonal water-level declines in response to groundwater pumping, the recorded water-level elevation in well $3 \mathrm{~S}$ remains higher than in well 3M, which indicates a net downward movement of groundwater. Unfortunately, age tracer data are not available for well $3 \mathrm{M}$ but are available for well $3 \mathrm{D}$, which was screened near the bottom of the aquifer (fig. 13A). Wells $3 \mathrm{~S}, 3 \mathrm{M}$, and $3 \mathrm{D}$ are screened within a zone characterized as aquifer material and test hole 7-LE-99 indicates some interbedded fine-grained deposits of clay and silt/loess that separate the screen intervals (fig. 13A). The AEM profile indicates there is no fine-grained cap mantling the aquifer material. Water-level recovery for wells $3 \mathrm{~S}$ and $3 \mathrm{M}$ after groundwater pumping in the summers of 2015 and 2016 is gradual rather than sharp, which is indicative of an unconfined aquifer (Chen, 1999). Repeated sampling indicates that nitrate concentrations from well $3 \mathrm{~S}$ often exceed $10 \mathrm{mg} / \mathrm{L}$. Nitrate concentrations from well 3D are less than the background concentration of $2 \mathrm{mg} / \mathrm{L}$ (University of Nebraska-Lincoln, 2019). Denitrification is an important microbially mediated natural attenuation process where anaerobic microorganisms, in the absence of dissolved oxygen, reduce nitrate to generate energy and nitrogen gas (Green and Bekins, 2010). Unfortunately, the dissolved oxygen concentration was not reported for well $3 \mathrm{D}$, with the most recent sampling results given in table 5, so it cannot be determined if denitrification has played any role in reducing concentrations of nitrate. Age tracer sampling in 2007 revealed that groundwater sampled from well $3 \mathrm{~S}$ was approximately 21 years old and groundwater sampled from well 3D was considered pre-modern (recharged before 1950; table 5). The nitrate concentration at the time age tracers were sampled was $15.2 \mathrm{mg} / \mathrm{L}$ for well $3 \mathrm{~S}$ and $0.29 \mathrm{mg} / \mathrm{L}$ for well 3D. The 


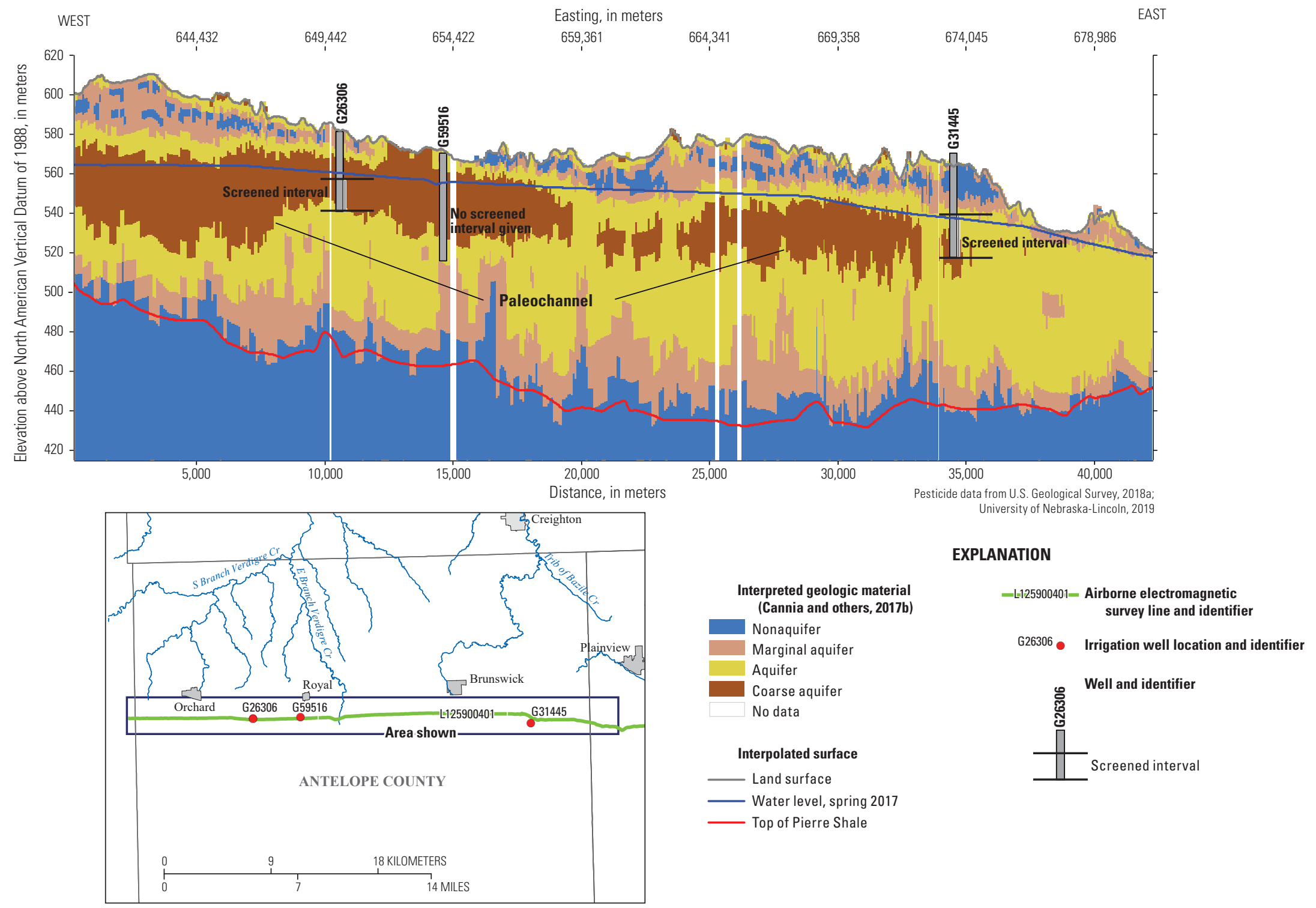

Figure 9. Interpreted geologic material of airborne electromagnetic profile (AEM) L125900401 and location of three irrigation wells with detectable concentrations of pesticides. The location of AEM profile L125900401 is shown in figure $3 A$. 


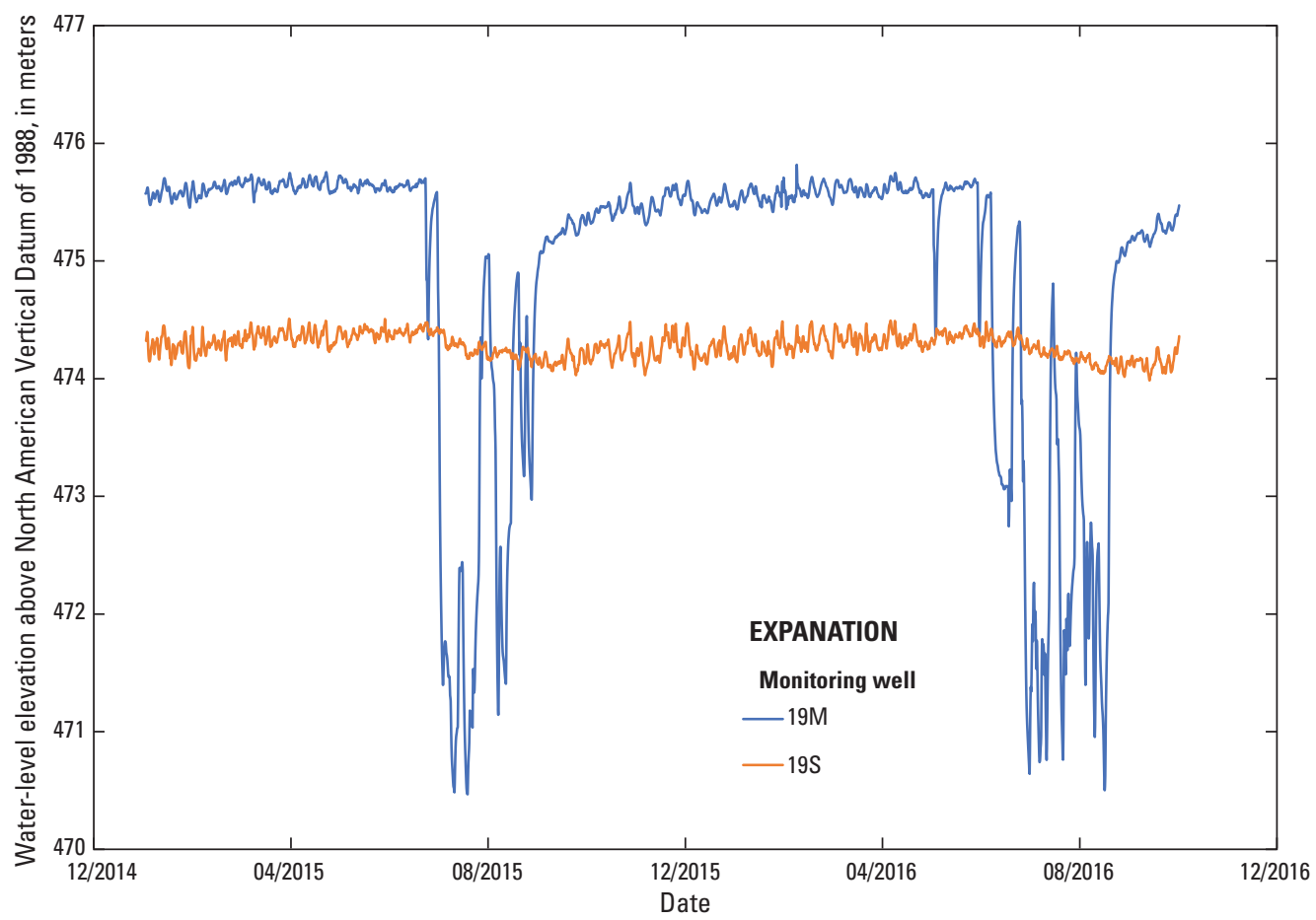

Figure 10. Continuous groundwater-level elevation data for monitoring wells 19S and 19M, Lower Elkhorn Natural Resources District, 2015-16. Water-level data from U.S. Geological Survey (2018a) furnished by the Lower Elkhorn Natural Resources District.

associated dissolved oxygen concentration for well $3 \mathrm{~S}$ was $8.4 \mathrm{mg} / \mathrm{L}$, which is considered oxic, and for well 3D was $0.5 \mathrm{mg} / \mathrm{L}$, which is considered anoxic. If the same geochemical conditions persist, it is possible that denitrification is playing a role in reducing nitrate concentrations and reducing the risk of contamination of the lower aquifer.

Monitoring wells 9M and 9D (fig. 4) are located within the Upper Elkhorn NRD west of Bazile Creek (fig. 1). Monitoring wells 9M and 9D show very similar seasonal water-level elevation trends to monitoring wells 19S and 19M in the Lower Elkhorn NRD in that there are much greater decreases in water levels in the deeper wells (9D and 19M) in each pair in response to groundwater pumping (figs. 10 and 14). Wells 9M and 9D and test hole 2-UE-01 are centered between four orthogonal AEM profiles (fig. 15). The hydrostratigraphic interpretation of the AEM data is projected onto user-defined profiles running northwest to southeast (A to $\mathrm{A}^{\prime}$ ) and southwest to northeast (B to B'). Test hole 2-UE-01 indicates wells 9M and 9D are both screened in the High Plains aquifer within sand and sandstone intervals separated by two thin (less than $5 \mathrm{~m}$ ) layers of silt (fig. 15; Conservation and Survey Division, University of Nebraska-Lincoln, 2019a). The measured water-level elevation in well $9 \mathrm{M}$ is at times higher than in well 9D during the nongrowing season months, indicating the net upward movement of groundwater. Groundwater pumping during the growing season caused larger water-level elevation declines in monitoring well 9D compared to 9M, resulting in the net downward movement of groundwater. It can be inferred that the two layers of silt separating the 9M and 9D screens are acting as ineffective confining layers (fig. 14). Age tracer sampling indicated that groundwater sampled from monitoring well $9 \mathrm{M}$ is approximately 23 years old (table 5). The net downward movement of groundwater appears to be affecting water quality of the deeper interval of the aquifer. The nitrate concentration of well 9M was $16.65 \mathrm{mg} / \mathrm{L}$ (table 5; Snow and Miller, 2018). The first nitrate result reported for well 9D was in 2002 and was less than $1 \mathrm{mg} / \mathrm{L}$; nitrate concentrations in well 9D have increased steadily since 2002; the most recent sample concentration of well 9D was $6.7 \mathrm{mg} / \mathrm{L}$ collected in July 18, 2014 (fig. 16; University of Nebraska-Lincoln, 2019). Well 9M and test hole 2-UE-01 are in the center of four profiles, all of which indicate no fine-grained cap and aquifer material outcrops at the surface of the profiles. If it is assumed that the silt layers are laterally persistent, then the AEM technique was not able to resolve the thin intervals of silt separating the screen intervals of wells 9M and 9D; however, additional mapping is needed to confirm this interpretation. Based on water-quality results and recorder data, the silt layers appear to be an ineffective confining unit and the lower aquifer is vulnerable to surface contamination.

Monitoring well 14S and 14M are completed in the High Plains aquifer and located within Antelope County along the southern border of the BGMA (fig. 4). Continuous water 


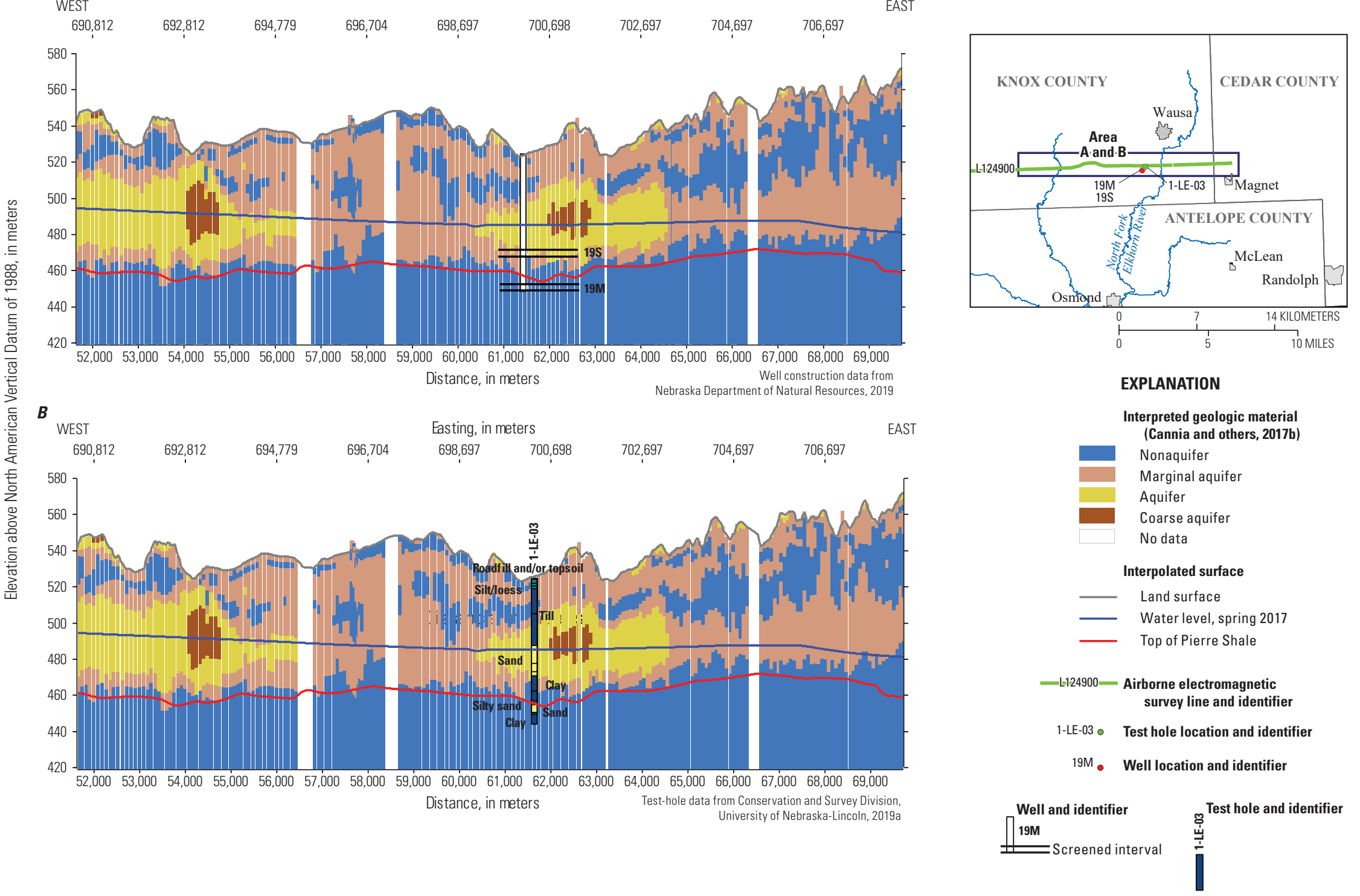

Figure 11. Interpreted geologic material of airborne electromagnetic (AEM) profile L124900, monitoring wells 19S and 19M, and test hole 1-LE-03. A, interpreted geologic material of AEM profile L124900. B, AEM profile L124900 and generalized lithology of test hole 1-LE-03. Monitoring wells $19 \mathrm{~S}$ and 19M are approximately 400 meters south of AEM profile L124900. Test hole 1-LE-03 is approximately 105 meters south of AEM profile L124900. The location of AEM profile L124900 is shown in figure $3 A$. 


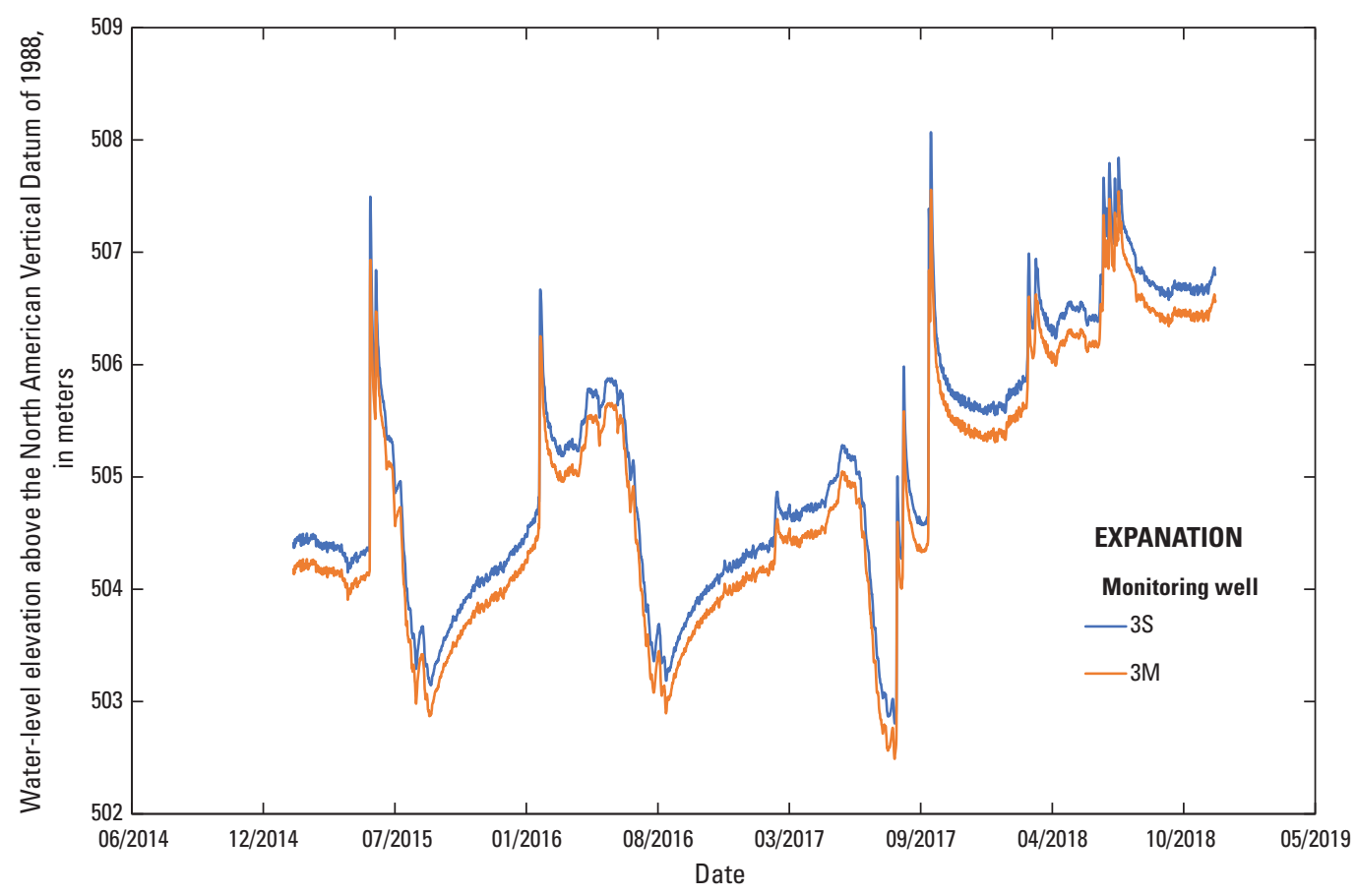

Figure 12. Continuous groundwater-level elevation data for monitoring wells $3 S$ and $3 \mathrm{M}$, Lower Elkhorn Natural Resources District, 2015-18. Water-level data from U.S. Geological Survey (2018a) furnished by the Lower Elkhorn Natural Resources District.

levels measured at monitoring well $14 \mathrm{~S}$ indicate that the area is affected by seasonal pumping (fig. 17). Water levels recover steadily, rather than abruptly, during the nongrowing season months, which is indicative of an unconfined aquifer (Chen, 1999). Age tracer sampling in 2017 indicated that the age of the groundwater sampled from well $14 \mathrm{~S}$ was approximately 25 years old (table 5; Snow and Miller, 2018). Repeat sampling indicated that nitrate concentrations in well $14 \mathrm{~S}$ increased from 17.2 to $30.2 \mathrm{mg} / \mathrm{L}$ between 2003 and 2017 (table 5). Consistent with other well nests within the BGMA, the water quality in the lower part of the aquifer is different from the shallow part of the aquifer. Age tracer sampling in 2003 indicated that groundwater sampled from well 14M (fig. 4) was considered pre-modern, the associated nitrate concentration was less than $1 \mathrm{mg} / \mathrm{L}$, and dissolved oxygen was $9.8 \mathrm{mg} / \mathrm{L}$ (table 5), which indicates oxic conditions and that denitrification is likely not occurring. The most recent sample collected in 2014 from well 14M indicates that nitrate concentrations have remained less than $1 \mathrm{mg} / \mathrm{L}$ (table 5). Monitoring wells $14 \mathrm{~S}$ and $14 \mathrm{M}$ are located near the southern boundary of the BGMA area where there is a discontinuous cap of finegrained sediments mantling the aquifer (fig. 18). Nitrate data from well $14 \mathrm{~S}$ indicate that the discontinuous cap appears to be ineffective at preventing surface contamination. Test hole 7-UE-01 indicates about a 5-m clay layer that separates the monitoring wells screens $14 \mathrm{~S}$ and 14M (fig. 18). The AEM technique lacked the vertical resolution at depth to image and map this potentially important geologic layer. The collection of continuous water-level data could indicate if the clay layer is an effective hydrologic barrier, creating confining conditions in well $14 \mathrm{M}$ and possibly preventing groundwater contamination from the surface. 

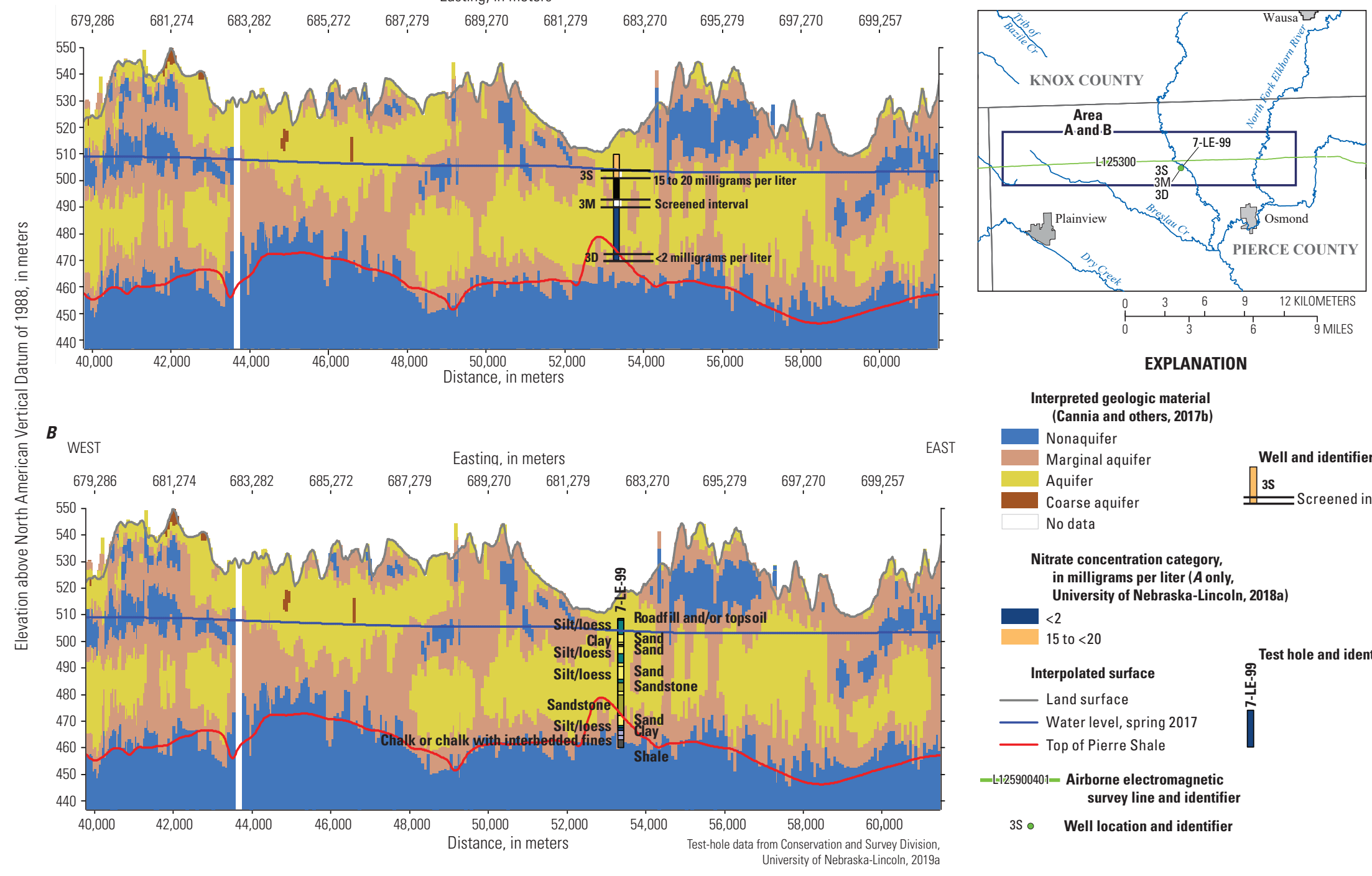

Interpreted geologic materia Cannia and others, 2017b)

Nonaquifer

Marginal aquifer

Aquifer

Well and identifier

Coarse aquifer

No data

\section{Nitrate concentration category,}

University of Nebraska-Lincoln, 2018a

15 to $<20$

Interpolated surface
- Land surface
- Water level, spring 2017
- Top of Pierre Shale
- L125900401- Airborne electromagnetic
survey line and identifier
$3 S$ Well location and identifier

Test hole and identifier

\section{空}

Figure 13. Interpreted geologic material of airborne electromagnetic (AEM) profile L125300 and nitrate concentration of wells $3 \mathrm{D}$ and $3 S$. $A$, interpreted geologic material of AEM profile L125300 and sampled nitrate concentration of wells 3D and 3S and screened interval of well 3M. B, AEM profile L125300 and generalized lithology of test hole 7-LE-99. Monitoring wells 3D and 3S and test hole 7-LE-99 are approximately 560 meters south of AEM profile L125300. The location of AEM profile L125300 is shown in figure $3 A$. 


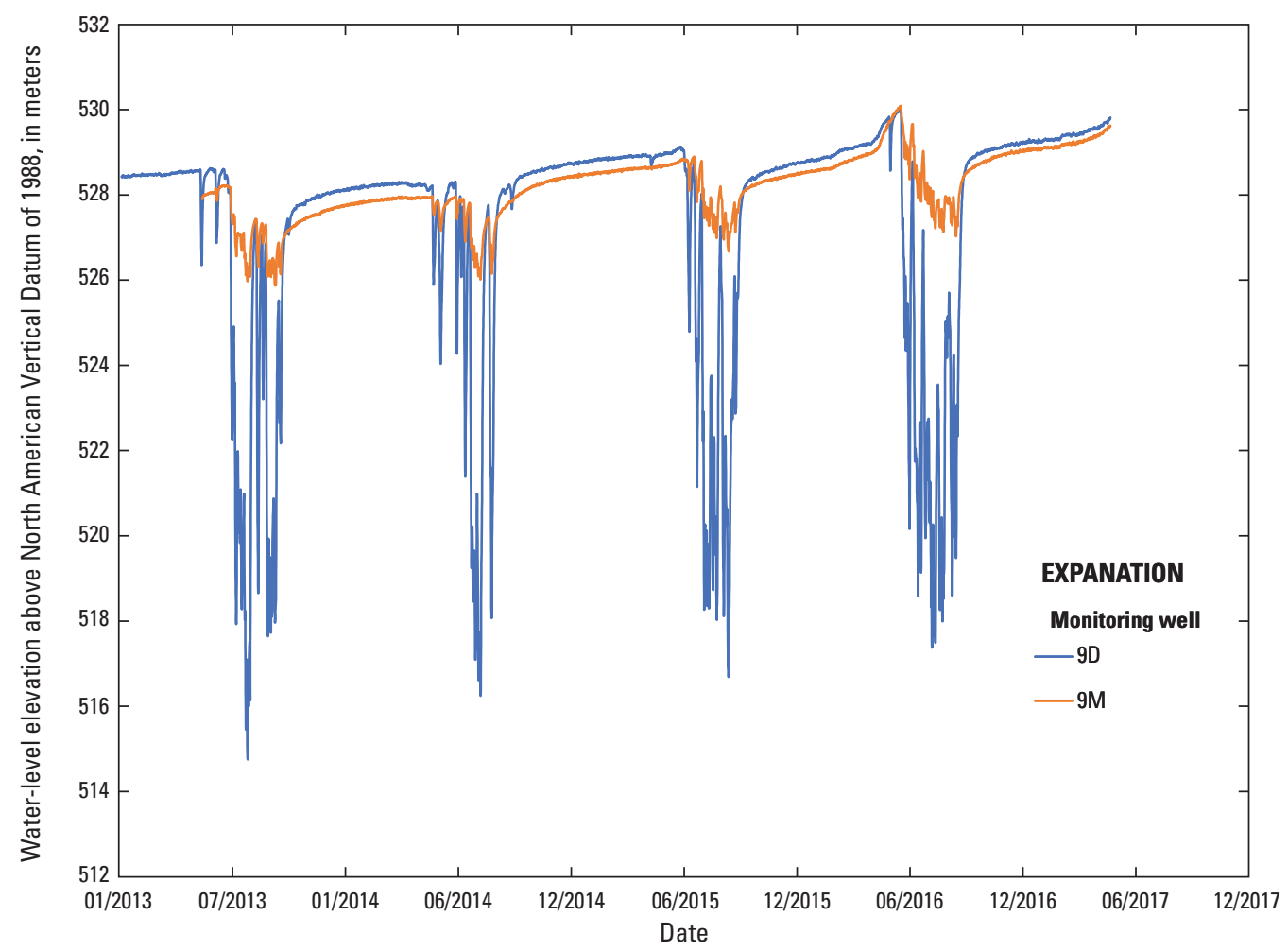

Figure 14. Continuous groundwater-level data for monitoring wells 9M and 9D, Upper Elkhorn Natural Resources District, 2013-17. Water-level data from U.S. Geological Survey (2018a) furnished by the Upper Elkhorn Natural Resources District.

\section{Potential Future Data Collection to Inform Groundwater Management}

This section describes gaps for which future data collection could enhance the existing hydrogeologic framework and improve understanding of movement of surface contaminants within the groundwater system and the role of denitrification in nitrate attenuation. Identified gaps are based on the comprehensive interpretation of AEM and existing water-level and water-quality data to inform and guide future water management decisions within the BGMA.

Additional continuous water-level data would complement the enhanced hydrogeologic framework and provide context for understanding aquifer confinement and connectivity within the BGMA. Because nearly all monitoring wells within the BGMA show seasonal water-level declines in response to groundwater irrigation, some aquifer characteristics can be discerned from the interpretation of continuous water-level data. Some of the most informative continuous water-level data are collected simultaneously from nested monitoring wells at the same location, which are often screened within discrete permeable zones sometimes separated by fine-grained intervals of silt or clay. Wells 19S and 19M in the Lower Elkhorn NRD and wells 9M and 9D in the Upper Elkhorn
NRD show how groundwater pumping can reverse hydraulic gradients and facilitate the downward movement of nitrate into deeper parts of the aquifer. Given the density of irrigation wells within the BGMA, this type of seasonal trend in water levels is likely prevalent in other areas. The reversal in hydraulic gradient likely would have been missed if only collecting discrete water levels in spring or fall months. Understanding seasonal water-level changes can allow water managers to better predict and assess the vulnerability of groundwater in deeper parts of the aquifer.

Dissolved oxygen measurements are essential for describing geochemical conditions of sampled groundwater. Groundwater sampling and monitoring within the BGMA is focused almost entirely on nitrate. During the past 40 years, the agrichemical clearinghouse has reported nearly 8,000 nitrate results from within the BGMA (University of Nebraska-Lincoln, 2019). Although the dataset is invaluable for assessing changes in extent and magnitude of nitrate contamination, it provides little supporting information, such as the water level at the time of sampling or dissolved oxygen concentration. Denitrification is an important microbially mediated natural attenuation process where anaerobic microorganisms, in the absence of dissolved oxygen, reduce nitrate to generate energy and nitrogen gas (Green and Bekins, 2010). Dissolved oxygen measurements are needed for assessing the 

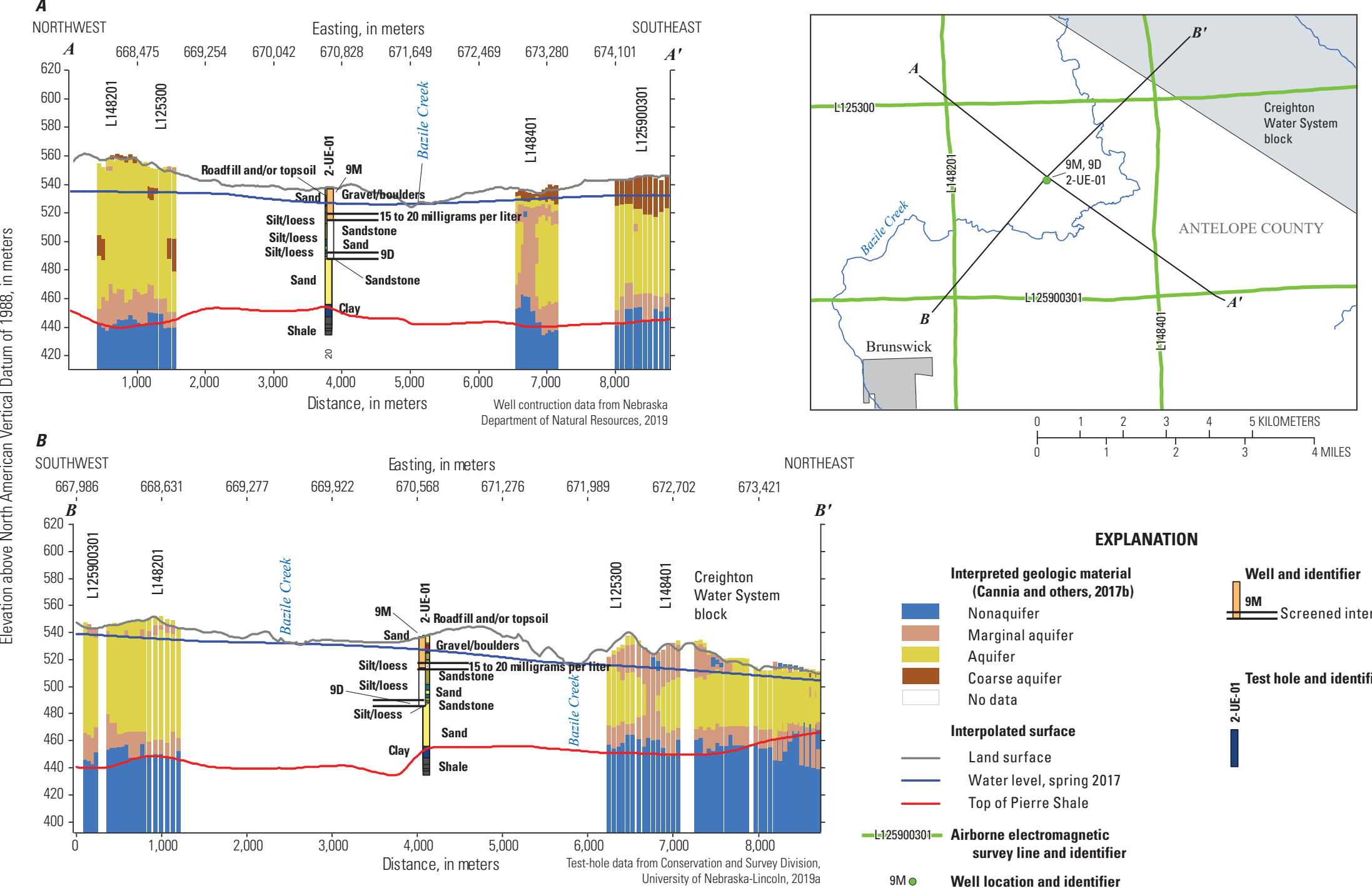

Figure 15. Interpreted geologic material of airborne electromagnetic (AEM) data projected onto user-defined profiles centering on monitoring wells $9 \mathrm{M}$ and $9 \mathrm{D}$ and test hole 2-UE-01. $A$, user-defined profile $\mathrm{A}$ to $\mathrm{A}^{\prime}$. $B$, user-defined profile $\mathrm{B}$ to $\mathrm{B}^{\prime}$. 


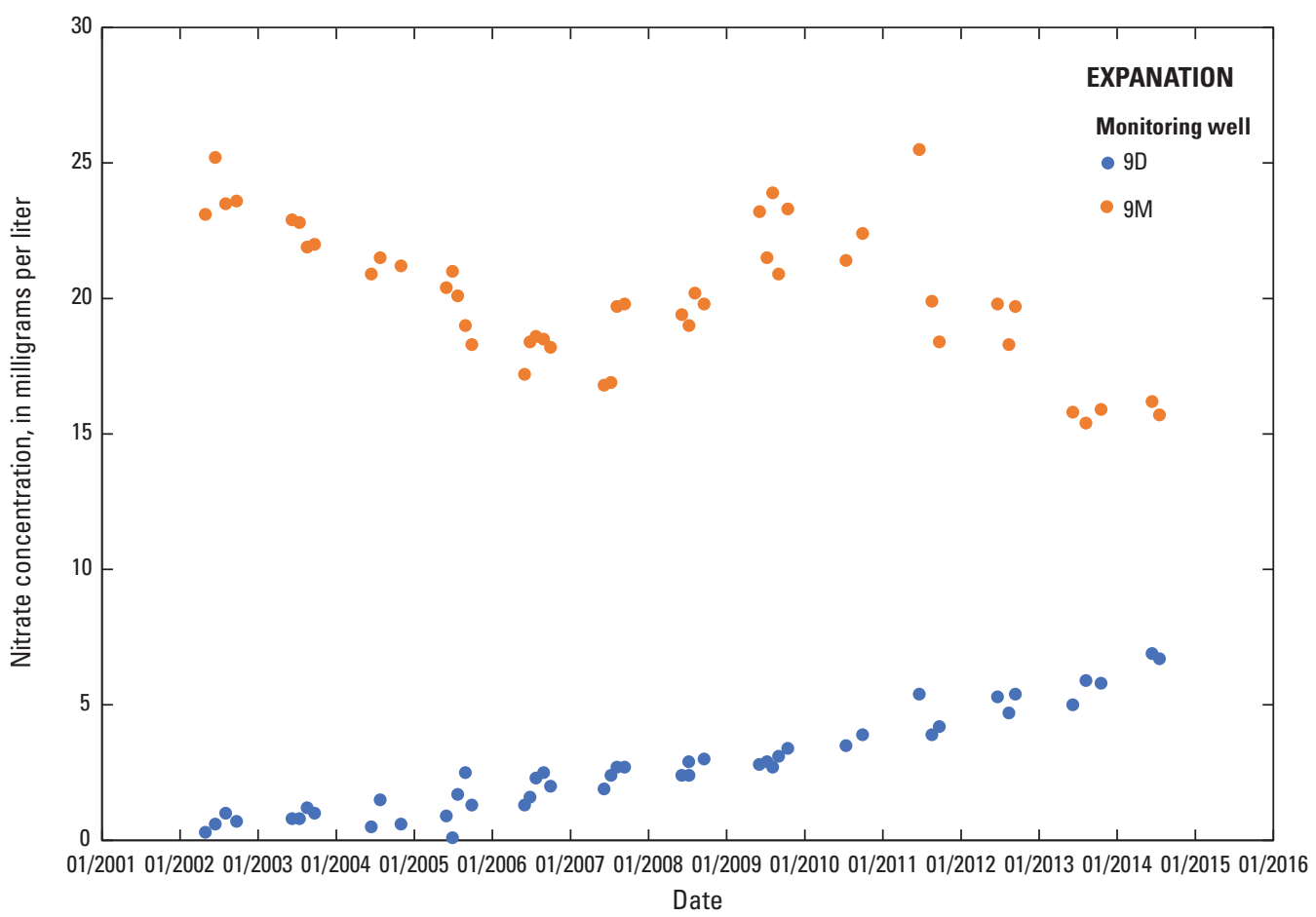

Figure 16. Nitrate concentration of sampled groundwater from monitoring wells 9M and 9D, Upper Elkhorn Natural Resources District, 2002-14. Nitrate concentration data from University of Nebraska-Lincoln (2019).

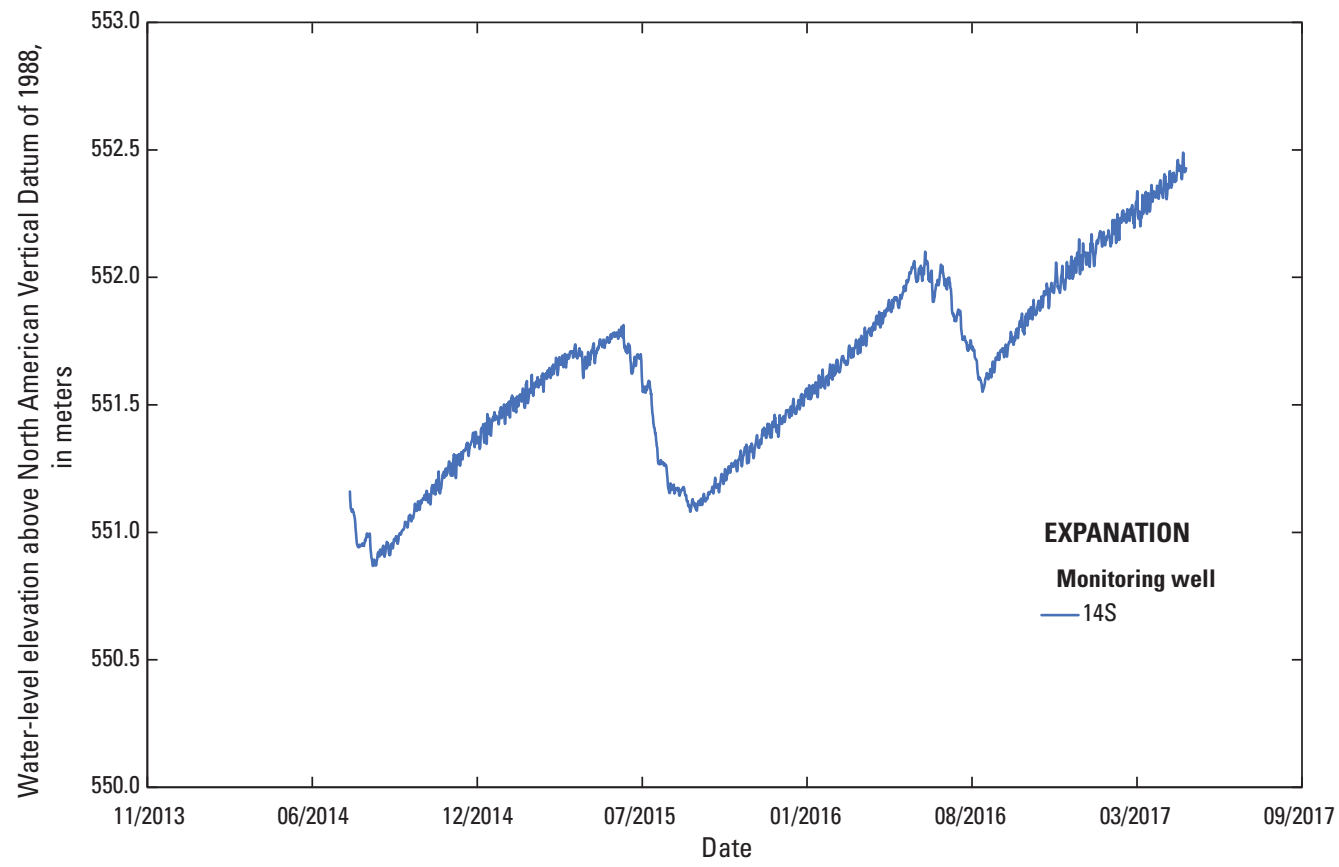

Figure 17. Continuous groundwater-level data for monitoring well 14S, Upper Elkhorn Natural Resources District, 2014-17. Water-level data from U.S. Geological Survey (2018a) furnished by the Upper Elkhorn Natural Resources District. 


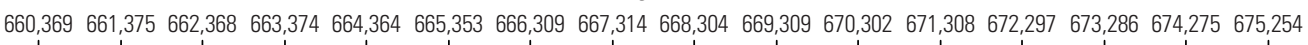

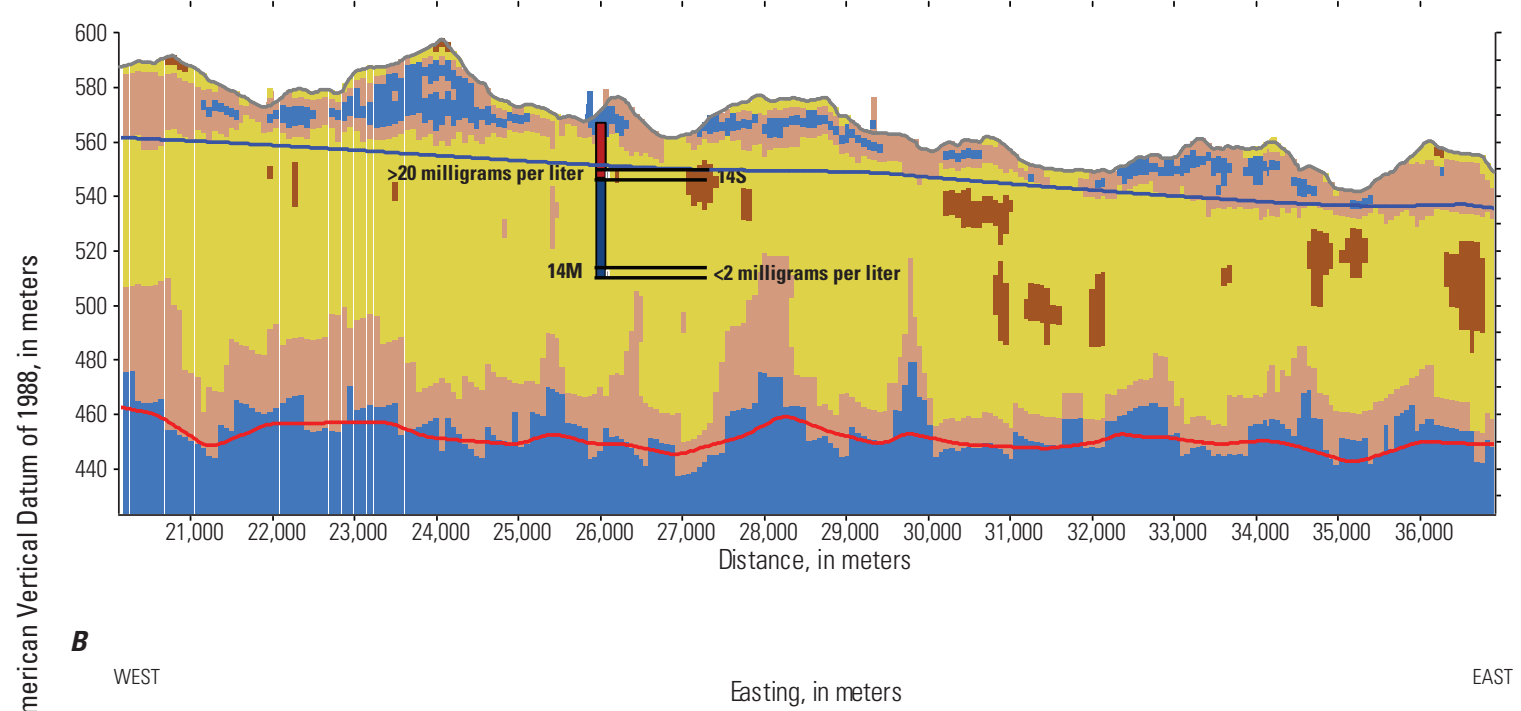

$660,369661,375$ 662,368 663,374 664,364 665,353 666,309 667,314 668,304 669,309 670,302 671,308 672,297 673,286 674,275 675,254

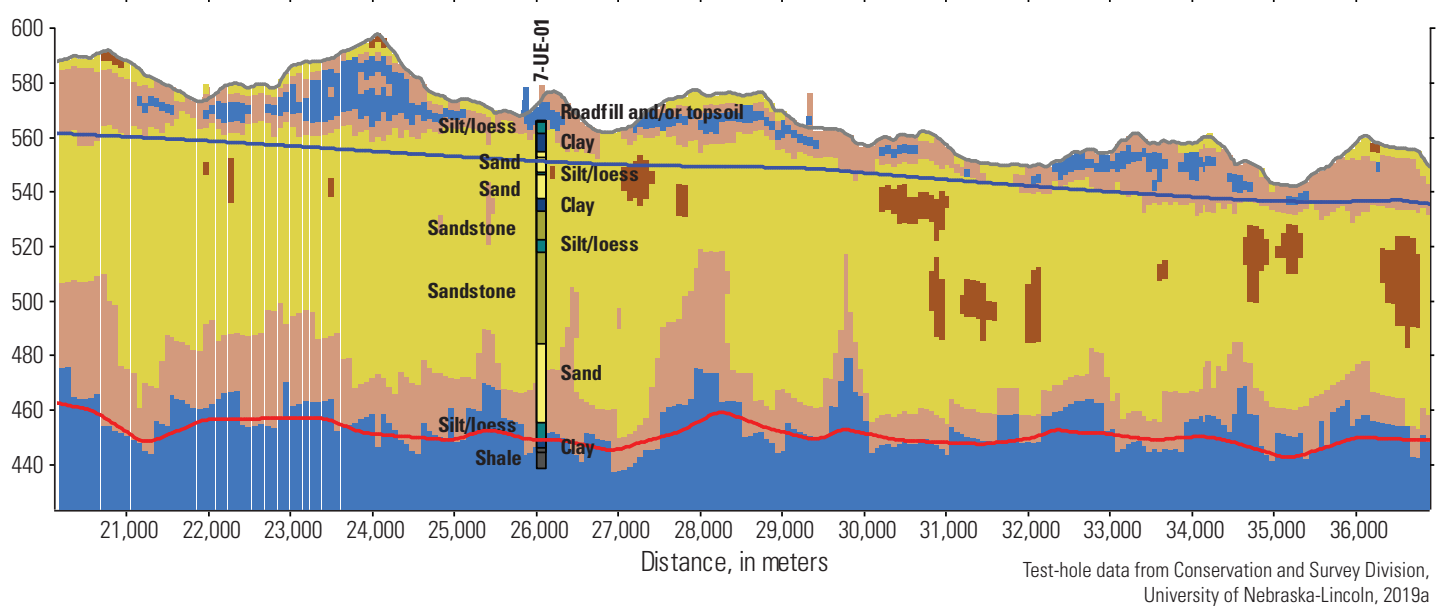

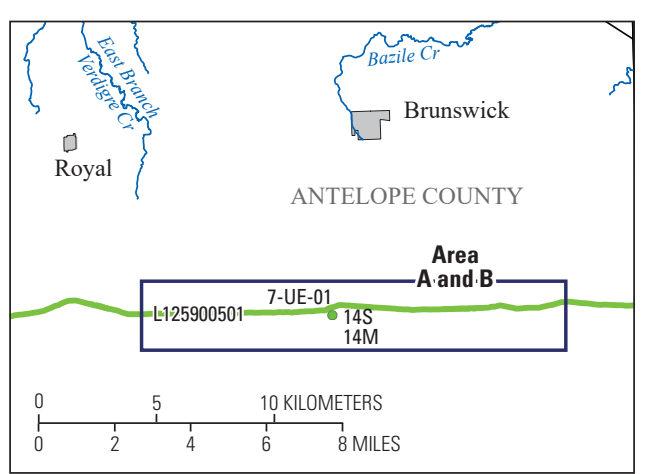

\section{EXPLANATION}

Interpreted geologic material (Cannia and others, 2017b)

Nonaquifer

Marginal aquifer

Aquifer

Coarse aquifer

No data

Nitrate concentration category, in milligrams per liter ( $\boldsymbol{A}$ only, University of Nebraska-Lincoln, 2018a; Snow and Miller, 2018)

\section{$<2$}

20 or greater

Interpolated surface

_ Land surface

Water level, spring 2017

— Top of Pierre Shale

\section{- L125900501- Airborne electromagnetic} survey line and identifier

14S - Well location and identifier

Figure 18. Interpreted geologic material for airborne electromagnetic (AEM) profile L125900501 and nitrate concentration of monitoring wells $14 \mathrm{~S}$ and $14 \mathrm{M}$. $A$, interpreted geologic material of AEM profile L125900501 and sampled nitrate concentration of wells 14S and 14M. B, AEM profile L125900501 and generalized lithology of test hole 7-UE-01. Monitoring wells 14 S and 14M and test hole 7-UE-01 are approximately 560 meters south of AEM profile L125900501. The location of AEM profile L125900501 is shown in figure $3 A$. 
prevalence of denitrification and are central to predicting the extent to which natural attenuation may help control nitrate concentrations in groundwater.

Within the BGMA there is need for continued monitoring of groundwater quality in deeper parts of the aquifer where groundwater is generally characterized as pre-modern with low concentrations of nitrate. Groundwater sampled from deeper monitoring wells most likely was recharged from a distant source prior to the widespread use of commercial fertilizer. Irrigation wells drilled within the BGMA often screen large thicknesses of the aquifer across thin, fine-grained layers separating permeable sand, gravel, and sandstone intervals. Landon and others (2008) documented instances where drilling through local confining layers induced downward ambient flow within irrigation wells, negatively affecting water quality. Continuous and discrete water-level data collected within the BGMA have indicated there are seasonally dependent, downward vertical hydraulic gradients that can provide an impetus for groundwater mixing that could negatively affect water quality.

Additional test-hole data would further constrain hydrogeologic interpretation and identify fine-grained layers that can control the movement of surface contaminants, affect groundwater recharge rates, and create confining conditions in the lower parts of aquifers. The hydrostratigraphic interpretation of AEM profiles indicated that shallow and deep monitoring wells were often screened within the same homogenous zone of aquifer material. In contrast, test-hole logs indicated that there often were fine-grained layers within these homogenous zones that separated the shallow and deep monitoring well screens, but these fine-grained layers were not detected by AEM because of decreased resolution of the AEM technique with depth. Additional test-hole data would further constrain hydrogeologic interpretations and identify fine-grained layers that may control the movement of surface contaminants, affect groundwater recharge rates, and allow for hydraulic confinement in the lower parts of the aquifer.

\section{Summary}

Airborne electromagnetic (AEM) surveys have greatly advanced hydrogeologic mapping and groundwater management efforts in Nebraska by providing cost-effective, high-resolution subsurface information. Starting in 2007, 13 Nebraska Natural Resources Districts (NRDs), the University of Nebraska-Lincoln's Conservation and Survey Division (CSD), and the U.S. Geological Survey (USGS) have invested nearly $\$ 18$ million to acquire more than 32,000 line-kilometers (20,000 line-miles) of AEM data in Nebraska. Despite the large investments in data collection, as of early 2020, there has been no coordinated effort to assemble, inventory, and manage the AEM data for long-term preservation in a centralized digital network. To protect taxpayer investments in AEM and realize maximum benefit of these data, the Lower Platte North,
Lower Platte South, Papio-Missouri River, Nemaha, Lower Loup, Central Platte, Upper Elkhorn, Lower Elkhorn, Lower Niobrara, and Lewis and Clark NRDs; the CSD, Nebraska Natural Resources Commission, Nebraska Department of Natural Resources; and the USGS entered a cooperative agreement to begin a program of data management and research aimed at understanding the best use of AEM for groundwater sustainability and management. The USGS and CSD are working jointly to provide technical support to cooperating NRDs to implement an AEM data preservation and research program titled the "Nebraska Geocloud." The Nebraska Geocloud project will facilitate data archiving and public access to information and provide guidelines that will maximize cost-effectiveness of future AEM studies within the State of Nebraska.

The purpose of this report is to present analyses of hydrogeologic data to support groundwater management within the Bazile Groundwater Management Area (BGMA) in northeastern Nebraska. Specifically, for this report, groundwater age tracer and nitrate data from several studies, which included all or parts of the BGMA, were assembled and jointly interpreted with AEM data within a three-dimensional environment. The combined age tracer dataset was examined to determine groundwater residence time, understand historical nitrate loading to groundwater, and estimate groundwater recharge or agricultural contaminant movement rates. Age tracer and nitrate data indicate that recent recharge or "modern" groundwater had nitrate concentrations that exceeded a background concentration of 2 milligrams per liter $(\mathrm{mg} / \mathrm{L})$. For the purposes of this report, modern groundwater was considered to have recharged less than 50 years from the time of sampling. In the BGMA area, nitrate concentrations for modern groundwater collected at the time of age tracer sampling ranged from 1.96 to $35.3 \mathrm{mg} / \mathrm{L}$ with more than 70 percent of the samples exceeding the U.S. Environmental Protection Agency's maximum contaminate level of $10 \mathrm{mg} / \mathrm{L}$. Researchers have focused much of their work near Creighton, Nebraska, in an area characterized as having a relatively thin unsaturated zone consisting of primarily coarse sediments overlying a thin (less than $20 \mathrm{~m}$ thick), coarse part of the High Plains aquifer. In this location, elevated concentrations of nitrate are reported for shallow and deep monitoring wells. Fine-grained materials are discontinuous and largely limited to the southern part of the Creighton Water System block flight area. Profile L128701 and wells ML-6D, ML-6M, and ML-6S are approximately 4 kilometers northeast of Creighton, where the unsaturated zone is relatively thin, and the High Plains aquifer is less than $20 \mathrm{~m}$ thick. At the location of these wells, groundwater is considered modern and nitrate exceed the maximum contaminant level throughout the thickness of the aquifer.

In contrast, some samples collected from shallow and deep wells in BGMA areas with thicker unsaturated zones and thicker aquifers indicate that groundwater was recharged more than 50 years ago, which for the purposes of this report is considered "pre-modern" groundwater. Nitrate concentrations of pre-modern groundwater collected at the time of sampling were generally less than the background concentration of 
$2 \mathrm{mg} / \mathrm{L}$. This low nitrate concentration indicates that either the High Plains aquifer is locally confined or semiconfined, or groundwater sampled in deeper wells followed a longer flow path from a distant recharge area and that deeper, pre-modern groundwater was not subjected to the same sources of nitrate as the shallow groundwater.

The hydrostratigraphic interpretation of AEM profiles indicated that shallow and deep monitoring wells were often screened within the same homogenous zone of aquifer material. In contrast, test-hole logs indicated that there often are fine-grained layers within these homogenous zones that separate the shallow and deep monitoring well screens, but that these fine-grained layers are not detected by AEM because of decreased resolution of the AEM technique with depth.

Estimates of groundwater recharge were used to evaluate the rates of contaminant movement and assess the vulnerability of groundwater resources to surface contamination. The calculated groundwater recharge rates were comparable to regional estimates from previous studies. Estimated groundwater recharge rates did not vary appreciably for the pasture/rangeland, dryland crops, or irrigated crop land use categories, which contradicts the results of some studies. A Kruskal-Wallis test determined that differences in distributions of recharge for each land use were not statistically significant, indicating that differences in land use are not the primary control on water movement through the unsaturated zone.

Detections of pesticides or their degradants from wells within the BGMA were clustered in two locations. One location is in the southwest part of the BGMA where coarse paleochannel deposits occur near land surface. Another location is east of Creighton, Nebr., within the Creighton Water System block flight area. In these locations, sampled wells with detectable concentrations of pesticides occur in areas also having high nitrate concentrations and a discontinuous cap of fine-grained material.

Continuous water-level data collected within the BGMA were examined together within the hydrostratigraphic interpretation of AEM profiles in Geoscene3D software. Continuous water levels collected within the BGMA typically display water-level declines in response to groundwater irrigation during growing season months (typically June through August). A comparison of the water levels in wells screened in shallow and deep parts of the High Plains aquifer can reveal the hydraulic connectivity of the shallow and deep parts of the High Plains aquifer, which is central to assessing the vulnerability of the deeper aquifer to surface contamination. Well nests 19S and 19M in the Lower Elkhorn NRD and wells 9M and 9D in the Upper Elkhorn NRD showed how groundwater pumping can reverse hydraulic gradients and facilitate the downward movement of nitrate into deeper parts of the High Plains aquifer. Given the density of irrigation wells within the BGMA, this type of seasonal trend in water levels is likely prevalent in other areas. The reversal in hydraulic gradient likely would have been missed if only collecting discrete water levels in spring or fall months. Understanding seasonal water-level changes can allow water managers to better predict and assess the vulnerability of groundwater in deeper parts of the aquifer.

Within the BGMA there is need for continued monitoring of groundwater quality in deeper parts of the High Plains aquifer where groundwater is generally characterized as pre-modern with low concentrations of nitrate. Groundwater sampled from deeper monitoring wells most likely was recharged from a distant source prior to the widespread use of commercial fertilizer. Irrigation wells drilled within the BGMA often screen large thicknesses of the aquifer across thin, fine-grained layers separating permeable sand, gravel, and sandstone intervals. Researchers have documented instances where drilling through local confining layers induced downward ambient flow within irrigation wells, negatively affecting water quality. Continuous and discrete water-level data collected within the BGMA have indicated there are seasonally dependent, downward vertical hydraulic gradients that can provide a pathway for groundwater mixing that could negatively affect water quality.

\section{References Cited}

Abraham, J.D., Cannia, J.C., Bedrosian, P.A., Johnson, M.R., Ball, L.B., and Sibray, S.S., 2012, Airborne electromagnetic mapping of the base of aquifer in areas of western Nebraska: U.S. Geological Survey Scientific Investigations Report 2011-5219, 38 p. [Also available at https://doi.org/ 10.3133/sir20115219.]

Adams, C.D., and Thurman, E.M., 1991, Formation and transport of deethylatrazine in the soil and vadose zone, Journal of Environmental Quality, v. 20, no. 3,8 p. [Also available at https://doi.org/10.2134/ jeq1991.00472425002000030007x.]

Biella, G., Lozej, A., and Tabacco, I., 1983, Experimental study of some hydrogeophysical properties of unconsolidated porous media: Ground Water, v. 21, no. 6, p. 741-751. [Also available at https://doi.org/10.1111/j.1745-6584.1983. tb01945.x.]

Burbach, M.E., and Spalding, R.F., 2000, Evaluation and assessment of agrichemical contaminants in the Creighton, NE area-Final report for the Lewis and Clark Natural Resources District: University of Nebraska-Lincoln Water Center, $55 \mathrm{p}$.

Burchett, R.R., Dreeszen, V.H., Souders, V.L., and Prichard, G.E., 1988, Bedrock geologic map showing configuration of the bedrock surface in the Nebraska part of the Sioux City 1 degree by 2 degrees Quadrangle: U.S. Geological Survey Miscellaneous Investigations Series Map I-1879, scale 1:250,000 [Also available at https://doi.org/10.3133/i1879.] 
Cannia, J.C., Abraham, J.D., and Asch, T.H., 2017a, Hydrogeologic framework of selected areas in the Lower Elkhorn Natural Resources District: Aqua Geo Frameworks, 125 p.

Cannia, J.C., Abraham, J.D., and Asch, T.H., 2017b, Mapping the hydrogeology of the Bazile Groundwater Management Area with airborne electromagnetics surveys: Aqua Geo Frameworks, $165 \mathrm{p}$.

Carney, C.P., Abraham, J.D., Cannia, J.C., and Steele, G.V., 2015a, Final report on airborne electromagnetic geophysical surveys and hydrogeologic framework development for the Eastern Nebraska Water Resources Assessment-Volume I. Including Lewis \& Clark, Lower Elkhorn, and the PapioMissouri Natural Resources District: Exploration Resources International, 152 p., accessed May 14, 2019, at http://www. enwra.org/aem\%20data\%20download.html.

Carney, C.P., Abraham, J.D., Cannia, J.C., and Steele, G.V., 2015b, Final report on airborne electromagnetic geophysical surveys and hydrogeologic framework development for the Eastern Nebraska Water Resources Assessment—Volume II. Including Lower Platte North, Lower Platte South, and Nemaha Natural Resources District: Exploration Resources International, 180 p., accessed June 2019 at http://www. enwra.org/aem\%20data\%20download.html.

Center for Advanced Land Management Information Technologies, 2007, 2005 Nebraska land use patterns: Lincoln, Nebr., University of Nebraska-Lincoln, geospatial data, accessed May 14, 2019, at https://nnr.nebraska.gov/sites/ dnr.nebraska.gov/files/doc/data/land-use/landuse.zip.

Chen, X.H., 1999, Determination of unconfined aquifer hydraulic properties from recovery test data: Journal of the American Water Resources Association, v. 35, no. 4, p. 983-990, accessed May 14, 2019, at https://doi.org/ 10.1111/j.1752-1688.1999.tb04188.x.

Christiansen, A.V., and Auken, E., 2012, A global measure for depth of investigation: Geophysics, v. 77, no. 4, p. WB171WB177. [Also available at https://doi.org/10.1190/geo20110393.1.]

Condon, S.M., 2005, Geologic studies of the Platte River, south-central Nebraska and adjacent areas-Geologic maps, subsurface study, and geologic history: U.S. Geological Survey Professional Paper 1706, 63 p. [Also available at https://doi.org/10.3133/pp1706.]

Condra, G.E., and Reed, E.C., 1943, The geological section of Nebraska: Lincoln, Nebr., University of Nebraska-Lincoln, Conservation and Survey Division, Nebraska Geological Survey Bulletin, v. 14, p. 82.
Conservation and Survey Division, University of NebraskaLincoln, 2008, Mean annual precipitation, $1971-2000$ and generalized gaining/losing streams: University of NebraskaLincoln, Institute of Agriculture and Natural Resources, accessed June 5, 2019, at https:/watercenter.unl.edu/ resources/publications/PrecipGainLose.pdf.

Conservation and Survey Division, University of NebraskaLincoln, 2019a, Nebraska statewide test-hole database: University of Nebraska-Lincoln, Institute of Agriculture and Natural Resources, digital data, accessed May 8, 2019, at http://snr.unl.edu/data/geologysoils/NebraskaTestHole/ NebraskaTestHoleIntro.aspx.

Conservation and Survey Division, University of NebraskaLincoln, 2019b, Till-Geology related GIS data: University of Nebraska-Lincoln, Institute of Agriculture and Natural Resources, digital data, accessed May 14, 2019, at http://snr. unl.edu/csd-esic/download/geographygis/utm/till_utm.zip.

Conservation and Survey Division, University of NebraskaLincoln, 2019c, Topographic regions, 2019: University of Nebraska-Lincoln, Institute of Agriculture and Natural Resources, digital data, accessed May 14, 2019, at http://snr. unl.edu/csd-esic/download/geographygis/utm/toporeg_utm. zip.

Delin, G.N., Healy, R.W., Landon, M.K., and Böhlke, J.-K., 2000, Effects of topography and soil properties on recharge at two sites in an agricultural field: Journal of the American Water Resources Association, v. 36, no. 6, p. 1401-1416. [Also available at https://doi.org/10.1111/j.1752-1688.2000. tb05735.x.]

Delin, G.N., Healy, R.W., Lorenz, D.L., and Nimmo, J.R., 2007, Comparison of local- to regional-scale estimates of ground-water recharge in Minnesota, USA: Journal of Hydrology (Amsterdam), v. 334, no. 1-2, p. 231-249. [Also available at https://doi.org/10.1016/j.jhydrol.2006.10.010.]

Dieter, C.A., Linsey, K.S., Caldwell, R.R., Harris, M.A., Ivahnenko, T.I., Lovelace, J.K., Maupin, M.A., and Barber, N.L., 2018, Estimated use of water in the United States county-level data for 2015 (ver. 2.0, June 2018): U.S. Geological Survey data release, https://doi.org/10.5066/ F7TB15V5.

Diffendal, R.F., Jr., Voorhies, M.R., Voorhies, E.J., LaGarry, H.E., Timperley, C.L., and Perkins, M.E., 2008, Geologic map of the O'Neill $1^{\circ} \times 2^{\circ}$ quadrangle, Nebraska, with configurations of surfaces of formations: Lincoln, Nebr., University of Nebraska-Lincoln, Conservation and Survey Division, Geologic Map GMC-34, scale 1:250,000. 
Divine, D.P., Joeckel, R.M., Korus, J.T., Hanson, P.R., and Olafsen Lackey, S., 2009, Eastern Nebraska Water Resources Assessment (ENWRA), Introduction to a hydrogeological study: University of Nebraska-Lincoln Conservation and Survey Division Bulletin 1, accessed February 19, 2020, at http://enwra.org/media/enwra_overview. pdf.

Esri, 2019, ArcMap version 10.5: Redlands, Calif., Esri software documentation [online documentation and instructions included with GIS software].

Exner, M.E., Hirsch, A.J., and Spalding, R.F., 2014, Nebraska's groundwater legacy - Nitrate contamination beneath irrigated cropland: Water Resources Research, v. 50, no. 5, p. 4474-4489. [Also available at https://doi.org/10.1002/ 2013WR015073.]

Exploration Resources International, 2015, Airborne electromagnetic geophysical surveys and hydrogeologic framework development for selected sites in the Lower Elkhorn Natural Resources District: Vicksburg, Miss., Exploration Resources International Geophysics LLC, 103 p. [Also available at http://www.enwra.org/LENRD2014AEMDataDownload.html.]

Fitterman, D.V., and Labson, V.F., 2005, Electromagnetic induction methods for environmental problems, in Butler, D.K., ed., Near surface geophysics: Tulsa, Okla., Society of Exploration Geophysicists, SEG Investigations in Geophysics Series, no. 13, p. 301-355.

Flynn, A.T., and Stanton, J.S., 2018, Simulation of groundwater flow, 1895-2010, and effects of additional groundwater withdrawals on future stream base flow in the Elkhorn and Loup River Basins, central Nebraska-Phase three: U.S. Geological Survey Scientific Investigations Report 2018-5106, 65 p. [Also available at https://doi.org/10.3133/ sir20185106.]

Gates, J.B., Steele, G.V., Nasta, P., and Szilagyi, J., 2014, Lithologic influences on groundwater recharge through incised glacial till from profile to regional scales-Evidence from glaciated Eastern Nebraska: Water Resources Research, v. 50, no. 1, p. 466-481. [Also available at https://doi.org/ 10.1002/2013WR014073.]

Gosselin, D.C., 1991, Bazile Triangle groundwater quality study, Nebraska: University of Nebraska Conservation and Survey Division Water Survey Paper No. 68, 29 p. [Also available at https://digitalcommons.unl.edu/conservationsurvey/146/.]

Green, C.T., and Bekins, B.A., 2010, Sustainability of natural attenuation of nitrate in agricultural aquifers: U.S. Geological Survey Fact Sheet 2010-3077, 4 p. [Also available at https://doi.org/10.3133/fs20103077.]
Gutentag, E.D., Heimes, F.J., Krothe, N.C., Luckey, R.R., and Weeks, J.B., 1984, Geohydrology of the High Plains aquifer in parts of Colorado, Nebraska, New Mexico, Oklahoma, South Dakota, Texas, and Wyoming: U.S. Geological Survey Professional Paper 1400-B, 63 p. [Also available at https://doi.org/10.3133/pp1400B.]

Helgesen, J.O., Leonard, R.B., and Wolf, R.J., 1993, Hydrology of the Great Plains aquifer system in Nebraska, Colorado, Kansas, and adjacent areas: U.S. Geological Survey Professional Paper 1414-E, 80 p., 10 plates. [Also available at https://doi.org/10.3133/pp1414E.]

Helsel, D.R., and Hirsch, R.M., 2002, Statistical methods in water resources: U.S. Geological Survey Techniques of Water-Resources Investigations, book 4, chap. A3, 522 p.

Hendee, D., 2015, Less water and more nitrates equals a troubling brew for public health: The Omaha World Herald, accessed January 11, 2017, at https://www.omaha.com/ outdoors/less-water-and-more-nitrates-equals-a-troublingbrew-for/article_8f96645d-094f-5837-a3a0-f543efa3bc9e. html.

Hinkle, S.R., Shapiro, S.D., Plummer, L.N., Busenberg, E., Widman, P.K., Casile, G.C., and Wayland, J.E., 2010, Estimates of tracer-based piston-flow ages of groundwater from selected sites-National Water-Quality Assessment Program, 1992-2005: U.S. Geological Survey Scientific Investigations Report 2010-5229, 90 p.

Hobza, C.M., 2020, Interpolated groundwater-level surface, spring 2017, Bazile Groundwater Management Area, northeastern Nebraska: U.S. Geological Survey data release, https://doi.org/10.5066/P9F3RVXN.

Hobza, C.M., Bedrosian, P.A., and Bloss, B.R., 2012, Hydrostratigraphic interpretation of test-hole and surface geophysical data, Elkhorn and Loup River Basins, Nebraska, 2008 to 2011: U.S. Geological Survey Open-File Report 2012-1227, 95 p. [Also available at https://doi.org/10.3133/ ofr20121227.]

Hobza, C.M., Abraham, J.D., Cannia, J.C., Johnson, M.R., and Sibray, S.S., 2014, Base of principal aquifer for parts of the North Platte, South Platte, and Twin Platte Natural Resources Districts, western Nebraska: U.S. Geological Survey Scientific Investigations Map 3310, 2 sheets, accessed January 29, 2020, at https://dx.doi.org/10.3133/ $\operatorname{sim} 3310$.

Houston, N.A., Gonzales-Bradford, S.L., Flynn, A.T., Qi, S.L., Peterson, S.M., Stanton, J.S., Ryter, D.W., Sohl, T.L., and Senay, G.B., 2013, Geodatabase compilation of hydrogeologic, remote sensing, and water-budget-component data for the High Plains aquifer, 2011: U.S. Geological Survey Data Series 777, 12 p. [Also available at https://doi.org/10.3133/ ds777.] 
I-GIS, 2019, Geoscene3D: Aarhus, Denmark, accessed May 9, 2019, at https:/www.geoscene3d.com/software/geoscene3d.

Johnson, A.I., 1967, Specific yield-Compilation of specific yields for various materials: U.S. Geological Survey Water Supply Paper 1662-D, 74 p. [Also available at https://pubs. usgs.gov/wsp/1662d/report.pdf.]

Jurgens, B.C., Böhlke, J.-K., and Eberts, S.M., 2012, Trac$\operatorname{erLPM}\left(\right.$ Version 1)-An Excel ${ }^{\circledR}$ workbook for interpreting groundwater age distributions from environmental tracer data: U.S. Geological Survey Techniques and Methods, book 4, chap. F3, 60 p. [Also available at https://pubs.usgs. gov/tm/4-f3/pdf/tm4-F3.pdf.]

Kazemi, G.A., Lehr, J.H., and Perrochet, P., 2006, Groundwater age: Hoboken, N.J., John Wiley and Sons, Inc., 325 p. [Also available at https://doi.org/10.1002/0471929514.]

Keller, G.V., 1987, Rock and mineral properties, in Nabighian, M.N., ed., Electromagnetic methods in applied geophysics theory v. 1: Tulsa, Okla., Society of Exploration Geophysicists, p. 13-51.

Korus, J.T., 2018, Combining hydraulic head analysis with airborne electromagnetics to detect and map impermeable aquifer boundaries: Water, v. 10, no. 8, 18 p. [Also available at https://doi.org/10.3390/w10080975.]

Korus, J.T., Joeckel, R.M., Divine, D.P., and Abraham, J.D., 2016, Three-dimensional architecture and hydrostratigraphy of cross-cutting buried valleys using airborne electromagnetics, glaciated Central Lowlands, Nebraska, USA: Sedimentology, v. 64, no. 2, p. 553-581. [Also available at https://doi.org/10.1111/sed.12314.]

Korus, J.T., Howard, L.M., Young, A.R., Divine, D.P., Burbach, M.E., Jess, J.M., and Hallum, D.R., 2013, The groundwater atlas of Nebraska-Resource atlas no. 4b (3rd ed.): Lincoln, Nebr., University of Nebraska-Lincoln, Conservation and Survey Division, 64 p.

Korus, J.T., Divine, D.P., Hanson, P.R., and Dillon, J.S., 2012, Three geologic cross-sections across portions of eastern Nebraska showing Quaternary lithologic units and stratigraphy of uppermost bedrock: University of Nebraska-Lincoln Conservation and Survey Division Correlations and Cross sections (CCS) 18, 16 p. [Also available at https://www.enwra.org/media/CCS18_Korus-Divine-Hanson-Dillon.pdf.]

Korus, J.T., and Joeckel, R.M., 2011, Generalized geologic and hydrostratigraphic framework of Nebraska 2011, ver. 2: Lincoln, Conservation and Survey Division, University of Nebraska-Lincoln, Geologic Maps and Charts (GMC) 38.
Kwader, T., 1985, Estimating aquifer permeability from formation resistivity factors: Ground Water, v. 23, no. 6, p. 762-766. [Also available at https://doi.org/10.1111/ j.1745-6584.1985.tb01955.x.]

Landon, M.K., Clark, B.R., McMahon, P.B., McGuire, V.L., and Turco, M.J., 2008, Hydrogeology, chemical characteristics, and transport processes in the zone of contribution of a public-supply well in York, Nebraska: U.S. Geological Survey Scientific Investigations Report 2008-5050, 149 p., accessed March 31, 2020, at https://pubs.usgs.gov/sir/2008/ 5050/pdf/sir_2008-5050.pdf.

Maupin, M.A., Kenny, J.F., Hutson, S.S., Lovelace, J.K., Barber, N.L., and Linsey, K.S., 2014, Estimated use of water in the United States in 2010: U.S. Geological Survey Circular 1405, 56 p. [Also available at https://dx.doi.org/10.3133/ cir1405.]

McGuire, V.L., 2017, Water-level and recoverable water in storage changes, High Plains aquifer, predevelopment to 2015 and 2013-15: U.S. Geological Survey Scientific Investigations Report 2017-5040, 14 p. [Also available at https://doi.org/10.3133/sir20175040.]

McGuire, V.L., Lund, K.D., and Densmore, B.K., 2012, Saturated thickness and water in storage in the High Plains aquifer, 2009, and water-level changes and changes in water in storage in the High Plains aquifer, 1980 to 1995,1995 to 2000, 2000 to 2005, and 2005 to 2009: U.S. Geological Survey Scientific Investigations Report 2012-5177, 28 p. [Also available at https://doi.org/10.3133/sir20125177.]

McGuire, V.L., and Peterson, S.M., 2008, Base of principal aquifer for the Elkhorn-Loup model area, north-central Nebraska: U.S. Geological Survey Scientific Investigations Map 3042, 1 sheet. [Also available at https://pubs.usgs.gov/sim/3042.]

Miller, J.A., and Appel, C.L., 1997, Ground water atlas of the United States, Segment 3 Kansas, Missouri, and Nebraska: U.S. Geologic Survey Hydrologic Atlas 730D, 24 p. [Also available at https://pubs.er.usgs.gov/publication/ha730D.]

Mueller, D.K., and Helsel, D.R., 1996, Nutrients in the nation's waters - Too much of a good thing?: U.S. Geological Survey Circular 1136, 24 p. [Also available at https:// pubs.usgs.gov/circ/1996/1136/report.pdf.]

National Center for Biotechnology Information, 2019, Some chemicals used as solvents and in polymer manufacture1,2-dichloropropane: accessed July 31, 2019, at https:// www.ncbi.nlm.nih.gov/books/NBK436257/. 
National Center for Environmental Information, 2019, 19812010 U.S. climate normals: Asheville, N.C., National Center for Environmental Information, digital data, accessed May 14, 2019, at https://www.ncdc.noaa.gov/cdo-web/ datatools/normals.

Nebraska Department of Natural Resources, 2019, Registered groundwater wells data retrieval: Nebraska Department of Water Resources, digital data, accessed March 31, 2020, at http://nednr.nebraska.gov/Dynamic/Wells/Wells.

Palacky, G.J., 1987, Resistivity characteristics of geologic targets, in Nabighian, M.N., ed., Electromagnetic methods in applied geophysics theory v. 1: Tulsa, Okla., Society of Exploration Geophysicists, p. 53-129.

Plummer, L.N., and Busenberg, E., 1999, Chlorofluorocarbons-Tools for dating and tracing young groundwater, chap. 15 of Environmental tracers in subsurface hydrology: Boston, Kluwer Academic Publishers, p. 441-478.

Qi, S.L., 2010, Digital map of the aquifer boundary of the High Plains aquifer in parts of Colorado, Kansas, Nebraska, New Mexico, Oklahoma, South Dakota, Texas, and Wyoming: U.S. Geological Survey Data Series 543, accessed January 29, 2020, at https://pubs.usgs.gov/ds/543/.

Richter-Ryerson, S., 2017, Project to make state's electromagnetic survey data available: University of Nebraska-Lincoln Nebraska Today article, accessed May 14, 2019, at https:// news.unl.edu/newsrooms/today/article/project-to-makestates-electromagnetic-survey-data-available/.

Smith, B.D., Abraham, J.D., Cannia, J.C., Steele, G.V., and Hill, P., 2008, Helicopter electromagnetic and magnetic geophysical survey data, Oakland, Ashland, and Firth study areas, eastern Nebraska, March 2007: U.S. Geological Survey Open-File Report 2008-1018, 31 p., 1 plate. [Also available at https://pubs.usgs.gov/of/2008/1018/.]

Smith, B.D., Abraham, J.D., Cannia, J.C., Minsley, B.J., Ball, L.B., Steele, G.V., and Deszcz-Pan, M., 2011, Helicopter electromagnetic and magnetic geophysical survey data, Swedeburg and Sprague study areas, eastern Nebraska, May 2009: U.S. Geological Survey Open-File Report 2010-1288, 37 p. [Also available at https://doi.org/10.3133/ ofr20101288.]

Snow, D.D., and Miller, D.N., 2018, Bazile Ground Water Management Area isotope and recharge study: Final project report, University of Nebraska-Lincoln Water Sciences Laboratory, Lincoln, Nebr., 17 p.

Souders, V.L., and Shaffer, F.B., 1969, Water resources of Antelope County, Nebraska: U.S. Geological Survey Hydrologic Investigations Atlas, HA-316 [Also available at https://doi.org/10.3133/ha316.]
Stanley, K.O., and Wayne, W.J., 1972, Epeirogenic and climatic controls of early Pleistocene fluvial sediment dispersal in Nebraska: Geological Society of America Bulletin, v. 83, no. 12, p. 3675-3690. [Also available at https://doi.org/ 10.1130/0016-7606(1972)83[3675:EACCOE]2.0.CO;2.]

Stanton, J.S., 2013, Base of the upper layer of the phase-three Elkhorn-Loup groundwater-flow model, north-central Nebraska: U.S. Geological Survey Scientific Investigations Map 3259, 1 sheet, accessed January 29, 2020, at https:// dx.doi.org/10.3133/sim3259.

Stanton, J.S., Qi, S.L., Ryter, D.W., Falk, S.E., Houston, N.A., Peterson, S.M., Westenbroek, S.M., and Christenson, S.C., 2011, Selected approaches to estimate water-budget components of the High Plains, 1940 through 1949 and 2000 through 2009: U.S. Geological Survey Scientific Investigations Report 2011-5183, 79 p. [Also available at https://doi. org/10.3133/sir20115183.]

Stanton, J.S., Landon, M.K., and Turco, M.J., 2007a, Groundwater age and quality in the High Plains Aquifer near Seward, Nebraska, 2003-04: U.S. Geological Survey Scientific Investigations Report 2007-5088, 37 p. [Also available at https://doi.org/10.3133/sir20075088.]

Stanton, J.S., Steele, G.V., and Vogel, J.R., 2007b, Occurrence of agricultural chemicals in shallow ground water and the unsaturated zone, northeast Nebraska glacial till, 2002-04: U.S. Geological Survey Scientific Investigations Report 2007-5228, 51 p. [Also available at https://doi.org/10.3133/ sir20075228.]

Steele, G.V., Gurdak, J.J., and Hobza, C.M., 2014, Water movement through the unsaturated zone of the High Plains Aquifer in the Central Platte Natural Resources District, Nebraska, 2008-12: U.S. Geological Survey Scientific Investigations Report 2014-5008, 51 p., plus tables and app. [Also available at https://dx.doi.org/10.3133/sir20145008.]

Summerside, S.E., Dreeszen, V.H., Hartung, S.L., Khisty, M.J., and Szilagyi, J., 2001, Update and revision of regional $1 \times 2$ degree water-table configuration maps for the state of Nebraska: University of Nebraska Conservation and Survey Division Open-File Report 73, 9 p.

Swinehart, J.B., and Diffendal, R.F., 1989, Geology, in Bleed, A.S., and Flowerday, C.A., eds., An atlas of the Sand Hills: Lincoln, Nebr., University of Nebraska, Conservation and Survey Division, Resource Atlas, no. 5a, p. 29-42.

Swinehart, J.B., Souders, V.L., DeGraw, H.M., and Diffendal, R.F., 1985, Cenozoic paleogeography of western Nebraska, in Flores, R.M., and Kaplan, S.S., eds., Cenozoic paleogeography of the west-central United States-Rocky Mountain Paleogeography Symposium, 3rd, Denver, 1985, Proceedings: Denver, Colo., Rocky Mountain Section, Society of Economic Paleontologists and Mineralogists, p. 209-229. 
Szilagyi, J., and Jozsa, J., 2013, MODIS-aided statewide net groundwater recharge estimation in Nebraska: Ground Water, v. 51, no. 5, p. 735-744. [Also available at https:// doi.org/10.1111/j.1745-6584.2012.01019.x.]

U.S. Department of Agriculture, 1994, Atrazine: Environmental Characteristics and Economics of Management, U.S. Department of Agriculture Agricultural Economic Report 699, accessed July 31, 2019, at https://www.ers.usda.gov/ webdocs/publications/40593/33085_aer699.pdf? $v=0$.

U.S. Environmental Protection Agency, 1995, Reregistration eligibility decision fact sheet for metolachlor: Office of Prevention, Pesticides and Toxic Substances, U.S. Environmental Protection Agency Fact Sheet EPA-738-F-95-007, accessed July 31, 2019, at https://www3.epa.gov/pesticides/ chem_search/reg_actions/reregistration/fs_PC-108801_1Apr-95.pdf.

U.S. Environmental Protection Agency, 1998a, Reregistration eligibility decision fact sheet for pendimethalin: Office of Prevention, Pesticides and Toxic Substances, U.S. Environmental Protection Agency Fact Sheet EPA-738-F-97-007, accessed July 31, 2019, at https://www3.epa.gov/pesticides/ chem_search/reg_actions/reregistration/fs_PC-108501_1Jun-97.pdf.

U.S. Environmental Protection Agency, 1998b, Reregistration eligibility decision fact sheet for alachlor: Office of Prevention, Pesticides and Toxic Substances, EPA-738-F-98-018, accessed June 12, 2019, at https://www3.epa.gov/pesticides/ chem_search/reg_actions/reregistration/fs_PC-090501_1Dec-98.pdf.

U.S. Environmental Protection Agency, 1998c, Notice of pesticide registration for 2-Chloro-4-isopropylamino-6-aminos-triazine: accessed June 12, 2019, at https://www3.epa.gov/ pesticides/chem_search/ppls/001812-00352-19980929.pdf.
U.S. Environmental Protection Agency, 2018, 2018 edition of the drinking water standards and health advisories, Office of Water, U.S. Environmental Protection Agency, accessed September 22, 2020, at https://www.epa.gov/sites/production/files/2018-03/documents/dwtable2018.pdf.

U.S. Geological Survey, 2018a, USGS water data for the Nation: U.S. Geological Survey National Water Information System database, accessed September 30, 2018, at https:// doi.org/10.5066/F7P55KJN.

U.S. Geological Survey, 2018b, The National Map-Web interface: accessed September 30, 2018, at https://viewer. nationalmap.gov/basic/.

University of Nebraska-Lincoln, 2008, Nebraska Water: University of Nebraska-Lincoln Water Center, Lincoln, Nebr., 1 plate.

University of Nebraska-Lincoln, 2019, Quality-assessed agrichemical contaminant database for Nebraska ground water-A cooperative project of the Nebraska Departments of Agriculture, Environmental Quality, and Natural Resources and the University of Nebraska-Lincoln: accessed June 6, 2019, at https://clearinghouse.nebraska. gov/Clearinghouse.aspx.

Upper Elkhorn Natural Resources District, 2016, Bazile groundwater management area plan: accessed May 15, 2019, at https://uenrd.org/_storage/pagefiles/ 2016bgma319approvedplan(1).pdf.

Young, A.R., Burbach, M.E., and Howard, L.M., 2016, Nebraska statewide groundwater-level monitoring report 2015: University of Nebraska - Lincoln, Conservation and Survey Division, School of Natural Resources, Nebraska Water Survey Paper Number 83, 28 p., accessed December 12, 2019, at http://snr.unl.edu/csd-esic/GWMapArchives/GWReports/GW_Level_Report_2015.pdf. 

For more information about this publication, contact:

Director, USGS Nebraska Water Science Center

5231 South 19th Street

Lincoln, NE 68512

402-328-4100

For additional information, visit: https://www.usgs.gov/ centers/ne-water

Publishing support provided by the

Rolla Publishing Service Center 


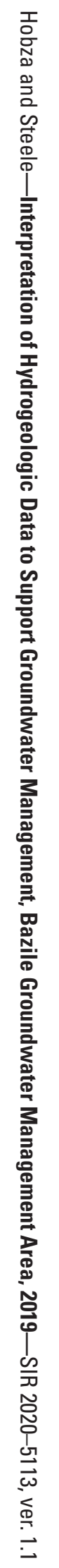

